\title{
DISTRIBUIÇÃO ESPACIAL E PLANO DE AMOSTRAGEM PARA A CIGARRINHA-DAS-RAÍZES, Mahanarva fimbriolata (Stål., 1854), EM CANA-DE-AÇÚCAR
}

\author{
ERICH STINGEL
}

Dissertação apresentada à Escola
Superior de Agricultura "Luiz de
Queiroz", Universidade de São Paulo,
para obtenção do título de Mestre em
Ciências, Área de Concentração:
Entomologia.

PIRACICABA

Estado de São Paulo - Brasil

Maio - 2005 


\title{
DISTRIBUIÇÃO ESPACIAL E PLANO DE AMOSTRAGEM PARA A CIGARRINHA-DAS-RAÍZES, Mahanarva fimbriolata (Stål., 1854), EM CANA-DE-AÇÚCAR
}

\author{
ERICH STINGEL
}

Engenheiro Agrônomo

Orientador: Prof. Dr. JOSÉ MAURÍCIO SIMÕES BENTO

Dissertação apresentada à Escola Superior de Agricultura "Luiz de Queiroz", Universidade de São Paulo, para obtenção do título de Mestre em Ciências, Área de Concentração: Entomologia.

\author{
PIRACICABA \\ Estado de São Paulo - Brasil \\ Maio - 2005
}


Dados I nt ernaci onai s de Cat al ogação na Publi cação ( $C l P$ ) DI VI SÃO DE BI BLI OTECA E DOCUMENTAÇÃO - ESALQI USP

Stingel, Erich

Distribuição espacial e plano de amostragem para a cigarrinha-das-raízes,

Mahanarva fimbriolata (Stål., 1854), em cana-de-açúcar / Erich Stingel. - - Piracicaba, 2005.

75 p. : il.

Dissertação (mestrado) - - Escola Superior de Agricultura Luiz de Queiroz, 2005. Bibliografia.

1. Amostragem 2. Distribuição espacial 3. Cana-de-açúcar 4. Cigarrinha-da-raiz 5. Manejo integrado 6. Ninfa 7. Praga de planta I. Título

CDD 633.61

"Permitida a cópia total ou parcial deste documento, desde que citada a fonte - o aut or" 


\section{A Deus,}

Por estar ao meu lado e me guiar em cada

passo dessa jornada,

\section{Agradeço}

Aos meus pais Douglas e Lea,

Por serem exemplo de vida e me ensinarem a ir

à busca dos meus ideais, com alegria, paciência

e determinação,

Dedico

À minha esposa Alessandra e filha Ana Laura, Pelo carinho, incentivo, compreensão e por serem a fonte de inspiração para eu seguir sempre em frente, 


\section{AGRADECIMENTOS}

Ao Prof. Dr. José Mauricio Simões Bento pela orientação, amizade, disponibilidade, paciência, estímulo constante e por ser exemplo de dedicação profissional;

À $\mathrm{Dr}^{\text {a }}$ Marinéia de Lara Haddad e ao Prof. Dr. Sinval Silveira Neto pela amizade, disponibilidade, paciência e auxílio na metodologia e análise dos dados;

À Copersucar e ao Centro de Tecnologia Canavieira (CTC) pela liberação e suporte financeiro para a realização do curso;

Ao Dr. Enrico De Beni Arrigoni (Coordenador de Recursos - CTC) pela autorização para a realização do curso, amizade, confiança, incentivo, participação na banca de qualificação, discussão de resultados e revisão do texto;

Ao Dr. William Lee Burnquist (Coordenador de Tecnologia - CTC) pela confiança, incentivo e auxílio no summary;

Ao Dr Álvaro Sanguino (Gestor de Tecnologia - CTC) pela amizade, confiança, incentivo e revisão do texto;

À consultora de RH do CTC, Márcia Regina Frasson pela amizade, incentivo e orientações administrativas; 
À Usina São Luiz S.A., especialmente aos Engenheiros Agrônomos Fernando Luiz Quagliato Filho e Manoel B. R. de Andrade, pela confiança, amizade, incentivo e por ceder os recursos necessários para a realização dos experimentos; aos técnicos Marcus Vinicius Lopes, João Marcelo Antunes e Marcelo Pereira Mendonça, pelo suporte; ao Líder agrícola José Carlos de Lima e equipe, pelo auxílio na realização dos levantamentos de campo, ao auxiliar administrativo Edson Fernando da Gama, pelo auxílio na organização dos dados, ao auxiliar de laboratório Valdinei da Costa pela valiosa ajuda na coleta de insetos para a coleção entomológica e à encarregada de laboratório Lucia Aparecida Carvalho pelo incentivo;

À Usina São Martinho, especialmente ao Eng ${ }^{\circ} \mathrm{Agr}^{\circ}$ Mário Ortiz Gandini, pela confiança e por ceder os recursos necessários para a realização do experimento; aos técnicos Marcos Antônio Marcari, José Luis dos Santos e Delair Vasconcelos, pelo suporte e ao líder agrícola Vicente Matos Viana e equipe, pelo auxílio na realização dos levantamentos de campo;

Ao Técnico agrícola Silvio Carlos Victor Primo (CTC) pela amizade, responsabilidade, grande empenho na condução dos experimentos e auxílio na organização de dados;

Ao $\mathrm{Eng}^{\circ} \mathrm{Agr}^{\circ}$ Luiz Carlos de Almeida e aos técnicos Carlos Roberto Rubio e Jorge Alves dos Santos (CTC), pelo auxílio nas avaliações dos experimentos;

À Bibliotecária Iraneuda Maria Cardinalli (CTC), pela amizade, incentivo, disponibilidade e auxílio na obtenção dos artigos científicos;

À secretária Eliete Coletti (CTC), pela amizade, incentivo, dedicação e auxílio na tabulação dos dados e editoração da dissertação;

Às secretárias Celma D. Cataldi de Lemos e Georgete Negri (CTC), pelo auxílio na formatação do plano de dissertação; 
Ao técnico de apoio Edvaldo Germin (CTC) pela amizade e auxílio na digitação dos dados experimentais;

Aos demais colegas do Centro de Tecnologia Canavieira (CTC) que, de alguma forma, contribuíram para a realização deste trabalho, em especial ao $\mathrm{Eng}^{\circ} \mathrm{Agr}^{\circ}$ Marcos Virgílio Casagrande (CTC), pela amizade, incentivo e troca de idéias sobre o trabalho; aos Engenheiros Agrônomos Jorge L. Donzelli, Luiz Antonio D. Paes e Célio Manechini, pelas informações técnicas; ao Estatístico Rubens Leite do Canto Braga, pelas sugestões e ao $\mathrm{Eng}^{\circ} \mathrm{Agr}^{\circ}$ Carlos Suguitani, pelo auxílio na formatação do texto;

Aos professores do Programa de Pós-Graduação em Entomologia da ESALQ-USP, pela dedicação, amizade e contribuição para minha formação profissional, em especial ao Dr. Sérgio Batista Alves e Dr. José Djair Vendramim, pela cordial discussão do plano de dissertação, sugestões e palavras de incentivo;

Aos colegas do curso de mestrado Eduardo Diehl, Eduardo Primiano, Elio Guzzo, João Fernando, José Wilson, Mariuxi Gomes e Priscila Fortes e demais colegas, pela amizade e agradável convívio durante a realização das disciplinas;

Aos funcionários do setor de Entomologia - ESALQ/USP, pela amizade, cordialidade e apoio na realização das atividades acadêmicas;

Aos funcionários da Biblioteca da ESALQ-USP, em especial às bibliotecárias Kátia Maria Andrade Ferraz, Silvia Maria Zinsly e Eliana Maria Garcia, pelas orientações na busca de artigos científicos e revisão das normas de editoração;

Aos meus familiares, pelo carinho, incentivo, compreensão e apoio nos momentos mais difíceis, em especial à minha sobrinha Marina, pela valiosa ajuda na coleta de insetos para a coleção entomológica;

À todos que contribuíram de alguma forma para a realização deste trabalho, os meus sinceros agradecimentos. 


\section{SUMÁRIO}

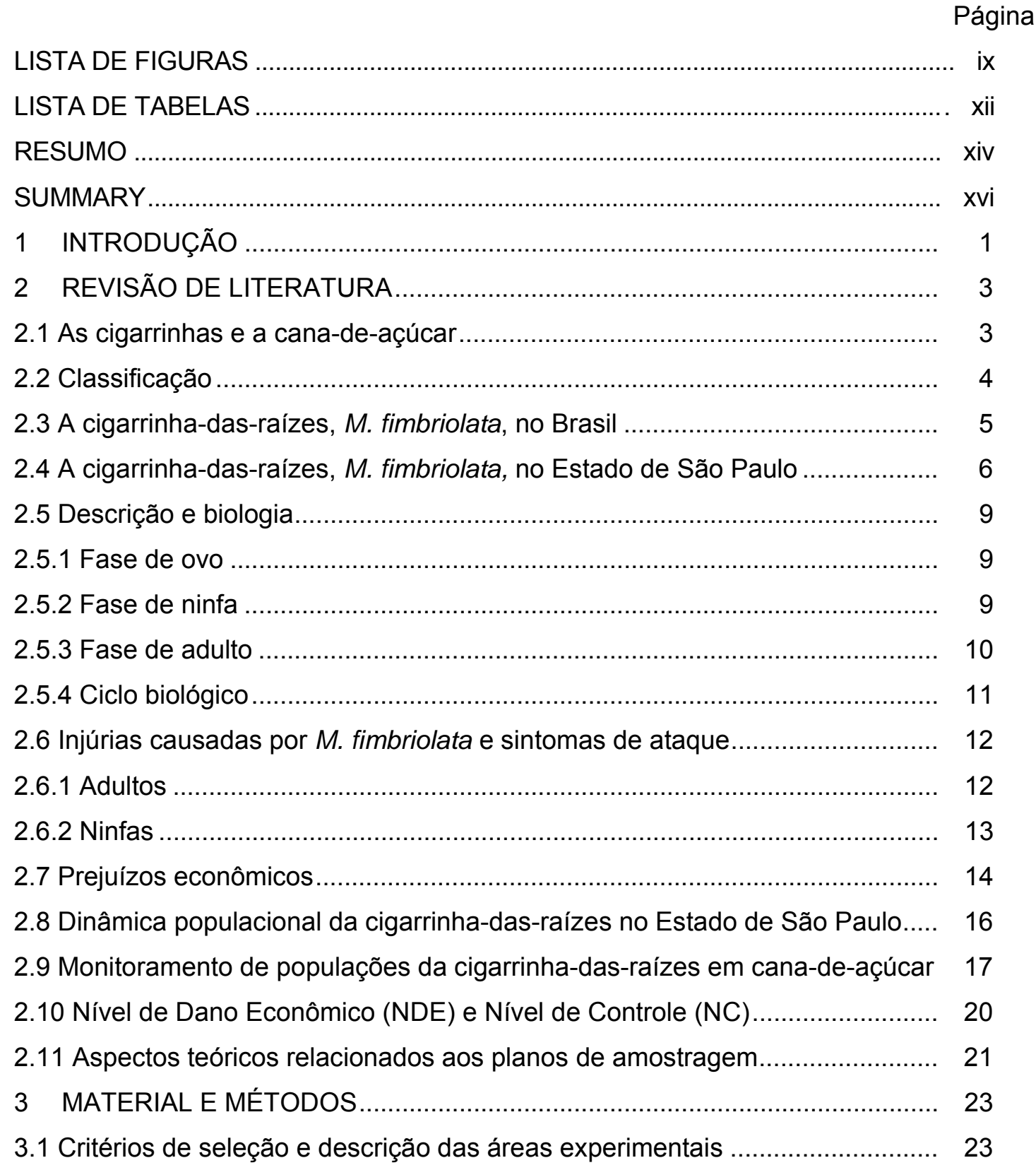


3.2 Estudo da distribuição espacial e plano de amostragem.

3.2.1 Instalação dos experimentos 25

3.2.2 Metodologia de avaliação 25

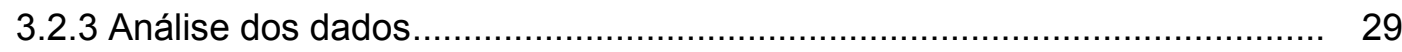

3.3 Avaliação do sistema de amostragem comercial...................................... 33

3.3.1 Instalação dos experimentos ............................................................. 33

3.3.2 Metodologia de avaliação ................................................................... 35

3.3.3 Análise de dados ............................................................................. 36

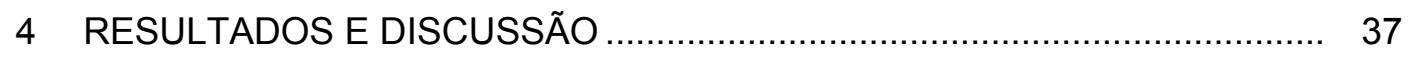

4.1 Estudo do modelo de distribuição espacial e plano de amostragem ............ 37

4.1.1 Modelo de distribuição espacial de ninfas .............................................. 37

4.1.2 Modelo de distribuição espacial de adultos ............................................ 46

4.1.3 Definição do tamanho da amostra e esquema de caminhamento .............. 48

4.2 Avaliação do sistema de amostragem comercial........................................... 58

4.2.1 Dinâmica populacional........................................................................ 58

4.2.2 Comparação da amostragem comercial e amostragem experimental........ 61

4.2.3 Relação entre número de espumas e ninfas ............................................. 64

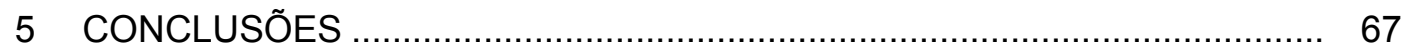

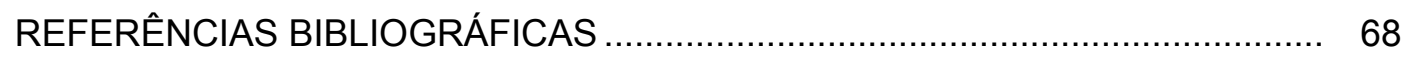




\section{LISTA DE FIGURAS}

Página

1 Distribuição dos pontos de amostragem na parcela do experimento conduzido em Ourinhos-SP, após a avaliação realizada em 29/10/2003.

2 Método de amostragem utilizado para Mahanarva fimbriolata em cana-deaçúcar: demarcação do ponto de amostragem com gabaritos $(A)$; remoção da palha da base das touceiras (B); contagem de formas biológicas da cigarrinha-das-raízes ao nível do solo $(C)$ e aspecto geral do ponto de amostragem após o levantamento (D).

3 Esquemas (A, B, C, D, E, e F) de caminhamento propostos para amostragem da população de ninfas da cigarrinha-das-raízes, Mahanarva fimbriolata, em cana-de-açúcar.

4 Demarcação dos pontos de amostragem na parcela do experimento para avaliação do sistema de amostragem comercial da cigarrinha-das-raízes, Mahanarva fimbriolata, em cana-de-açúcar.

5 Distribuição espacial de ninfas da cigarrinha da raiz, Mahanarva fimbriolata, em cana-de-açúcar. Fazenda Bela Vista, Ourinhos-SP, 29/10/2003 (Primeira época).

6 Distribuição espacial de ninfas da cigarrinha da raiz, Mahanarva fimbriolata, em cana-de-açúcar. Fazenda Bibiana, Guariba-SP, 11/11/2003 (Primeira época)

7 Distribuição espacial de ninfas da cigarrinha da raiz, Mahanarva fimbriolata, em cana-de-açúcar. Fazenda Bela Vista, Ourinhos-SP, 21/01/2004 (Segunda época).

8 Distribuição espacial de ninfas da cigarrinha da raiz, Mahanarva fimbriolata, em cana-de-açúcar. Fazenda Bibiana, Guariba-SP, 03/02/2004 (Segunda época) 
9 Distribuição espacial de ninfas da cigarrinha da raiz, Mahanarva fimbriolata, em cana-de-açúcar. Fazenda Bela Vista, Ourinhos-SP, 30/03/2004 (Terceira

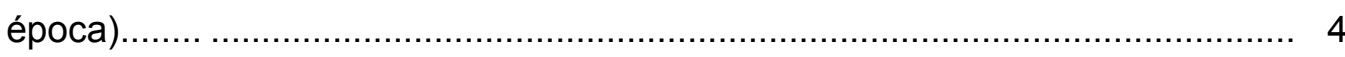

10 Distribuição espacial de ninfas da cigarrinha da raiz, Mahanarva fimbriolata, em cana-de-açúcar. Fazenda Bibiana, Guariba-SP, 05/04/2004 (Terceira época).

11 - Número de amostras necessárias para estimar a população de ninfas da cigarrinha-das-raízes, Mahanarva fimbriolata, em cana-de-açúcar, em função dos níveis de infestação e precisão admitido.

12 Esquema de amostragem proposto para o monitoramento da cigarrinha-dasraízes em programas de manejo integrado, na cultura da cana-de-açúcar.

13 Flutuação populacional da cigarrinha-das-raízes da cana-de-açúcar, Mahanarva fimbriolata, obtida na Fazenda Bela Vista, Ourinhos-SP, entre os meses de outubro de 2003 e setembro de 2004.

14 Flutuação populacional da cigarrinha-das-raízes da cana-de-açúcar, Mahanarva fimbriolata, obtida na Fazenda Água Suja, Ourinhos-SP, entre os meses de outubro de 2003 e setembro de 2004.

15 Equação de regressão linear, coeficiente de determinação e flutuação populacional de ninfas da cigarrinha-das-raízes da cana-de-açúcar, Mahanarva fimbriolata, para comparação dos dados da Amostragem Comercial $(A C)$ e Amostragem Experimental $(A E)$, realizadas nas Fazendas Bela Vista (A) e Água Suja (B), em Ourinhos-SP, entre os meses de outubro de 2003 e setembro de 2004 .

16 Equação de regressão linear, coeficiente de determinação e flutuação populacional de adultos da cigarrinha-das-raízes da cana-de-açúcar, Mahanarva fimbriolata, para comparação dos dados da Amostragem Comercial $(A C)$ e Amostragem Experimental ( $A E)$, realizadas nas Fazendas Bela Vista (A) e Água Suja (B), em Ourinhos-SP, entre os meses de outubro de 2003 e setembro de 2004 .

17 Relação entre o número de espumas e ninfas da cigarrinha-das-raízes, Mahanarva fimbriolata, em cana-de-açúcar, obtida na Amostragem Comercial (A) e Amostragem Experimental (B) realizada na Fazenda Água Suja em Ourinhos-SP 
18 Relação entre o número de espumas e ninfas da cigarrinha-das-raízes, Mahanarva fimbriolata, em cana-de-açúcar, obtida na Amostragem Comercial (A) e Amostragem Experimental (B) realizada na Fazenda Água Suja em Ourinhos-SP 


\section{LISTA DE TABELAS}

Página

1 Número total e médio de ninfas da cigarrinha-das-raízes, Mahanarva fimbriolata em cana-de-açúcar, encontradas em três épocas de amostragem em Ourinhos e Guariba-SP, entre 2003 e 2004 ( $N=3.600$ pontos de $1 \mathrm{~m}$ linear/época).

2 Índice de Morisita $\left(I_{\delta}\right)$ e valor de $F_{0}$ calculados com base na população de ninfas da cigarrinha-das-raízes, Mahanarva fimbriolata, em três épocas de amostragem em Ourinhos e Guariba-SP, entre 2003 e 2004.

3 Número total e médio de adultos da cigarrinha-das-raízes, Mahanarva fimbriolata em cana-de-açúcar, encontradas três épocas de amostragem em Ourinhos e Guariba-SP, entre 2003 e 2004 ( $N=3.600$ pontos de $1 \mathrm{~m}$ linear/época).

4 Índice de Morisita $\left(I_{\delta}\right)$ e valor de $F_{0}$ calculados com base na população de adultos da cigarrinha-das-raízes, Mahanarva fimbriolata, em três épocas de amostragem em Ourinhos e Guariba-SP, entre 2003 e 2004.

5 Valores de $\mathrm{k}$ inicial e ideal e índice médio de infestação de ninfas da cigarrinha-das-raízes, Mahanarva fimbriolata, em três épocas de amostragem em Ourinhos e Guariba-SP, entre 2003 e 2004.

6 Número de amostras/ha necessárias para estimar a população de ninfas da cigarrinha-das-raízes, Mahanarva fimbriolata, em função da infestação média de ninfas/m e dos níveis de precisão desejados.

7 Coeficientes hora-homem para a execução de diferentes planos de amostragem para avaliação da população de ninfas da cigarrinha-dasraízes, Mahanarva fimbriolata, em cana-de-açúcar. 
8 Valores de Variação Relativa (VR) calculados para simulações de amostragem da cigarrinha-das-raízes, Mahanarva fimbriolata, em cana-deaçúcar, comparando-se diferentes esquemas de caminhamento para cada tamanho de amostra

9 Valores de Precisão Relativa (PR) calculados para simulações de amostragem da cigarrinha-das-raízes, Mahanarva fimbriolata, em cana-deaçúcar, comparando-se diferentes esquemas de caminhamento para cada tamanho de amostra. 


\title{
DISTRIBUIÇÃO ESPACIAL E PLANO DE AMOSTRAGEM PARA A CIGARRINHA-DAS-RAÍZES, Mahanarva fimbriolata (Stål., 1854), EM CANA-DE-AÇÚCAR
}

\author{
Autor: ERICH STINGEL \\ Orientador: Prof. Dr. JOSÉ MAURÍCIO SIMÕES BENTO
}

RESUMO

O objetivo deste trabalho foi avaliar a distribuição espacial de adultos e ninfas da cigarrinha-das-raízes da cana-de-açúcar, Mahanarva fimbriolata (Stål., 1854) (Hemiptera: Cercopidae), a eficiência do sistema de amostragem atualmente empregado em escala comercial, a possibilidade de estimar a população de ninfas por meio da contagem de espumas e, a partir desses resultados, estabelecer um plano de amostragem confiável, prático e de baixo custo para utilização em programas de manejo integrado desta praga. A determinação da distribuição espacial foi feita em Ourinhos e Guariba-SP, demarcando-se três parcelas de 1,1 ha, em talhão colhido mecanicamente sem a queima da palha e com histórico de ataque da cigarrinha-dasraízes. As avaliações foram feitas em três épocas diferentes, contando-se o número de adultos e ninfas na base das touceiras, em $50 \%$ da área da parcela. Os adultos e ninfas de $M$. fimbriolata distribuem-se de forma agregada ou contagiosa na cultura da cana-de-açúcar e este padrão de distribuição não se altera ao longo das gerações, nem é influenciado pelo nível de infestação ou variedade cultivada. Utilizando-se os dados obtidos nestes experimentos calculou-se, para cada local e época de 
amostragem, o índice de dispersão k e o número de amostras necessárias para estimar a população de ninfas, considerando-se diferentes níveis de precisão, e realizaram-se simulações para diferentes tamanhos de amostra e esquemas de caminhamento. O plano de amostragem mais adequado para avaliação da população da cigarrinha-das-raízes em cana-de-açúcar foi determinado por meio do intervalo de confiança da média $(P \leq 0,05)$ para a Variação Relativa $(V R)$ e Precisão Relativa $(P R)$. Os melhores resultados foram obtidos com 18 amostras de 1 metro linear por hectare, distribuídas na área de forma sistemática. Para a avaliação do método de amostragem comercial, instalaram-se dois experimentos em Ourinhos, demarcando-se duas parcelas de 1,1 ha, nas mesmas condições anteriores. Quinzenalmente, quantificou-se o número de formas biológicas em 300 pontos de $1 \mathrm{~m}$ linear na parcela (amostragem experimental) e no restante da área do talhão (amostragem comercial), em 4 pontos de dois sulcos de $2 \mathrm{~m}$ lineares/ha. Comparando-se os dados por meio de uma análise de regressão linear verificou-se que o método de amostragem comercial apresentou boa precisão na estimativa da população de ninfas, porém foi pouco preciso para adultos. Sua acurácia foi baixa para ninfas e adultos, subestimando as populações reais. A relação entre as contagens de espumas e ninfas nas amostragens comercial e experimental foi avaliada por meio de uma análise de regressão linear, observando-se alta correlação entre estes parâmetros, com coeficientes de determinação superiores a 0,96 . Os resultados obtidos indicam que, independentemente da época de avaliação e do nível de infestação, é possível estimar a população de ninfas da cigarrinha-dasraízes em cana-de-açúcar por meio da contagem de espumas, com elevado grau de confiabilidade. 


\title{
SPATIAL PATTERN AND SAMPLING PLAN FOR SUGARCANE ROOT FROGHOPPER , Mahanarva fimbriolata (Stål., 1854)
}

\author{
Author: ERICH STINGEL \\ Adviser: Prof. Dr. JOSÉ MAURÍCIO SIMÕES BENTO
}

\section{SUMMARY}

The objective of this research was to evaluate the spatial distribution of adults and nymphs of the sugarcane root froghopper, Mahanarva fimbriolata (Stal, 1854) (Hemiptera: Cercopidae), to evaluate the efficiency of the sampling system presently used to monitor the populations in commercial fields, and to estimate nymph populations by counting foam spots. The results obtained in this work were used to establish a low cost and reliable sampling method in order to improve the integrated pest management program for the sugarcane root froghopper. The determination of the spatial distribution was conducted at Ourinhos and Guariba cities, São Paulo State, in three plots of 1.1 ha that had been mechanically harvested without burning and with a history of infestation with sugarcane root froghopper. The evaluations were made in three different periods, counting the number of both adults and nymphs at the base of the stools in $50 \%$ of the plot. The adults and the nymphs of $M$. fimbriolata were distributed in aggregated or contagious form and this pattern did not change during subsequent generations nor was influenced by either the level of infestation or cultivated variety. The data obtained in these experiments was used to estimate, for each site and sampling period, the dispersion index $k$ and the number of samples 
needed to estimate nymph populations, considering different levels of precision. The data was also used to simulate results with different sample sizes and sampling patterns. The most adequate sampling plan to evaluate sugarcane root froghopper populations was determined using the confidence interval of the mean at $\mathrm{P} \leq 0.05$ for the Relative Variation (RV) and Relative Precision (RP). The best results were obtained with 18 samples of 1 linear meter per hectare, distributed in the area in a systematic manner. For the evaluation of the commercial sampling method, two experiments were established at Ourinhos, using two 1.1 hectare plots. The number of biological forms in 300 spots of 1 linear meter in the plot (experimental sampling) were checked bi-weekly. Similarly, in the rest of the area, biological forms were counted in 4 spots of 2 linear meters per hectare (commercial sampling). Linear regression analysis presented that the commercial sampling method presented good efficiency for estimating nymphs populations but was not efficient in estimating adult populations. The sampling accuracy was low for both nymphs and adults, underestimating the true populations. The linear correlation between foam counts and nymph in both commercial and experimental sampling was high, with determination coefficient greater than $96 \%$. The results indicate that, independent of the period and level of infestation, it is possible to estimate the population of sugarcane root froghopper nymphs by counting foam spots. 


\section{INTRODUÇÃO}

O setor sucroalcooleiro ocupa posição de destaque no cenário socioeconômico brasileiro dada sua importância na geração de renda, empregos e divisas para o país. A cadeia produtiva da cana-de-açúcar é responsável por $8 \%$ do Produto Interno Bruto agrícola nacional, movimentando anualmente cerca de $\mathrm{R} \$ 11,5$ bilhões e gerando mais de 1 milhão de empregos diretos e 4 milhões de empregos indiretos (Unica, 2005).

No Brasil, a cana-de-açúcar ocupa cerca de 5,3 milhões de hectares, sendo a terceira cultura em área cultivada, atrás da soja e do milho (Secco, 2004; FNP, 2005). Na safra 03/04, estima-se que foram produzidas 352,6 milhões de toneladas de cana, que resultaram em 14,6 bilhões de litros de álcool e 23,8 milhões de toneladas de açúcar. Estes números fazem do Brasil o maior produtor mundial de cana-deaçúcar, açúcar e álcool (FNP, 2005).

O Estado de São Paulo com uma área cultivada de aproximadamente 2,8 milhões de hectares (FNP, 2005) é o principal produtor de cana-de-açúcar e seus derivados no Brasil, respondendo por $60 \%$ de todo o açúcar e álcool produzido e $70 \%$ das exportações brasileiras desses produtos (Unica, 2005).

O manejo da cultura da cana-de-açúcar vem passando por uma profunda transformação nos últimos anos, especialmente no Estado de São Paulo, motivada pela legislação ambiental que prevê a redução progressiva da queima nos canaviais até sua completa extinção em 2031 (Lei Estadual 11241/02 regulamentada pelo Decreto Estadual 47.700/03). Este processo teve início em meados da década de 90, quando quase $100 \%$ dos canaviais eram colhidos manualmente após a queima da palha (Macedo et al., 1997).

A adoção do sistema conhecido como "colheita mecanizada de cana crua" equacionou a questão econômica relacionada aos custos de produção e proporcionou inúmeros benefícios agronômicos e ambientais. Em contrapartida, a eliminação da 
queima e a presença de palha no ambiente modificaram, dentre outros aspectos, o perfil de pragas da cultura (Arrigoni, 1999), destacando-se o caso da cigarrinha-dasraízes da cana-de-açúcar, Mahanarva fimbriolata (Stål., 1854) (Hemiptera: Cercopidae), que encontrou nesse ambiente, condições mais favoráveis de sobrevivência (Dinardo-Miranda et al., 2001; Novaretti et al., 2001).

A cigarrinha-das-raízes, até então considerada uma praga de importância secundária para o Estado de São Paulo (Dinardo-Miranda et al., 1999), adquiriu o status de praga-chave da cana-de-açúcar e tornou-se um dos principais desafios técnicos a ser equacionado em áreas de colheita de cana crua (Macedo et al., 2002).

Os prejuízos atribuídos à cigarrinha-das-raízes, $M$ fimbriolata, são decorrentes da extração de seiva nas raízes e folhas da cana-de-açúcar por ninfas e adultos, respectivamente, e da injeção de toxinas pelos adultos durante o processo de sucção (Mendonça, 1996). Estudos revelam que o ataque desta praga pode resultar em perdas na produtividade agrícola que variam de 15 a $80 \%$, sendo freqüentemente superiores a 40\% (Guagliumi, 1969; El-Kadi, 1977), e na qualidade da matéria-prima com reduções de até $30 \%$ no teor de sacarose (Guagliumi, 1968; Dinardo-Miranda et al., 2000).

A despeito da importância da cigarrinha-das-raízes para a cultura da canade-açúcar, ainda não se dispõe de um método de amostragem baseado em critérios científicos, o que pode comprometer o processo de tomada de decisão sobre a melhor estratégia de manejo em áreas infestadas por esta praga.

Sendo assim, o presente trabalho teve os seguintes objetivos: (i) avaliar a precisão e a acurácia do sistema de amostragem atualmente utilizado pelos produtores para monitoramento da cigarrinha-das-raízes; (ii) determinar a forma de distribuição espacial de adultos e ninfas de M. fimbriolata, na cultura da cana-de-açúcar; (iii) sugerir um sistema de amostragem confiável, prático e de baixo custo, para ser empregado em programas de manejo integrado desta praga e (iv) avaliar a possibilidade de se estimar a população de ninfas por meio da contagem do número de espumas presentes na base das touceiras. 


\section{REVISÃO DE LITERATURA}

\subsection{As cigarrinhas e a cana-de-açúcar}

As cigarrinhas são insetos fitófagos pertencentes à ordem Hemiptera e à superfamília Cercopoidea, que sugam seiva das partes aéreas e raízes das plantas. Em geral, os representantes desta superfamília apresentam cores vivas e se diferenciam dos demais representantes da subordem Auchenorhyncha pelo aspecto da cabeça, do pronotum e pela disposição dos espinhos tibiais e tarsais das pernas posteriores (Costa Lima, 1942).

A presença de cigarrinhas é relatada em várias partes do mundo, sendo encontradas, com maior freqüência, nas regiões tropical e subtropical do globo (Fewkes, 1969). São consideradas pragas de importância econômica em diversos agroecossistemas, pois, além dos prejuízos diretos decorrentes da sucção contínua de seiva e das lesões e deformações que provocam, podem injetar substâncias tóxicas em seus hospedeiros (Gallo et al., 2002).

Estima-se que estes insetos sejam responsáveis por prejuízos anuais de até 2,1 bilhões de dólares à cultura cana-de-açúcar e pastagens em todo o mundo (Thompson, 2004). No Brasil, chega a ser um fator limitante para as gramíneas cultivadas em determinadas regiões (El-Kadi, 1977).

Em cana-de-açúcar, estes insetos são importantes no continente americano e algumas ilhas do Caribe (Fewkes, 1969). Ao todo são relatados 14 gêneros associados à cultura, dos quais a maior parte pertence à família Cercopidae (Fewkes, 1969), que é constituída por insetos pequenos ou de tamanho médio, saltadores e facilmente reconhecidos pela presença de uma espuma viscosa que recobre suas formas jovens (Costa Lima, 1942; Borror \& DeLong, 1969).

O gênero Aeneolamia é considerado o de maior importância econômica para a cana-de-açúcar, a nível mundial, em função do número de espécies que abrange e 
de sua vasta distribuição geográfica (Fewkes, 1969). Cigarrinhas radicícolas pertencentes a este gênero, encontram-se amplamente distribuídas na América Latina e Caribe e figuram entre as principais pragas da cultura no México, Venezuela e Trinidad (Mendonça, 1996).

No Brasil, o principal gênero é Mahanarva, destacando-se as espécies Mahanarva fimbriolata (Stål, 1854), Mahanarva posticata (Stål, 1855) e Mahanarva rubicunda indentata (Walker, 1858), conhecidas respectivamente, como cigarrinha-dasraízes, cigarrinha-das-folhas e cigarrinha-do-cartucho (Mendonça et al.,1996a).

Vivendo sobre diversas gramíneas no Brasil, antes mesmo da introdução da cana-de-açúcar, a cigarrinha-das-raízes, M. fimbriolata, adaptou-se rapidamente a esta cultura, que se tornou um de seus principais hospedeiros (Moreira, 1921). Em função dos elevados prejuízos econômicos causados à agroindústria açucareira, esta espécie foi a que mais chamou a atenção dos produtores brasileiros desde o início do século $\mathrm{XX}$ até a década de 60 , quando foram registrados ataques severos da cigarrinha-dasfolhas, M. posticata, em diversas regiões canavieiras do Nordeste do país (Guagliumi, 1969). Mais recentemente, a constatação do incremento de áreas infestadas na região Centro-Sul do país, especialmente no Estado de São Paulo, colocou a cigarrinha-dasraízes novamente em evidência.

\subsection{Classificação}

A cigarrinha-das-raízes da cana-de-açúcar, Mahanarva fimbriolata (Stål., 1854) pertence à ordem Hemiptera, superfamília Cercopoidea, família Cercopidae, subfamília Tomaspidinae e tribo Tomaspidini (Garcia, 2002).

Durante muito tempo a nomenclatura desta e de outras espécies pertencentes à superfamília Cercopoidea foi confusa. Guagliumi (1970), após revisar as alterações ocorridas na classificação taxonômica da cigarrinha-das-raízes, menciona que Stål, em 1854, a incluiu no gênero Monecphora Amyot \& Serville, 1843. Posteriormente Lallemand (1912) a transferiu para o gênero Tomaspis Amyot \& Serville, 1843, ficando conhecida como Tomaspis fimbriolata. Esta nomenclatura foi aceita até 1968 quando Fennah, baseando-se em características morfológicas e da genitália dos machos, transferiu esta espécie para o gênero Mahanarva Distant, 1909; recebendo o nome pelo qual ela é atualmente conhecida. 
Citações equivocadas foram comuns no passado, referindo-se a $M$. fimbriolata como Tomaspis parana, Tomaspis liturata e Sphenorhina liturata var. ruforivulata (Guagliumi, 1969). É muito provável que todas as citações destas espécies, publicadas até 1968, se refiram a M. fimbriolata (Fennah, 1968; Guagliumi, 1970).

\subsection{A cigarrinha-das-raízes, M. fimbriolata, no Brasil}

A cigarrinha-das-raízes, $M$. fimbriolata, pode ser encontrada em praticamente todas as regiões produtoras de cana-de-açúcar do país (Planalsucar, 1977), sendo mencionada como praga de várias gramíneas espontâneas e cultivadas (Gagliumi, 1969). Relatos de sua ocorrência foram feitos nos Estados do Rio Grande do Norte, Pará, Pernambuco, Alagoas, Sergipe, Bahia, Minas Gerais, Rio de Janeiro, Espírito Santo, São Paulo, Santa Catarina e Rio Grande do Sul (Guagliumi, 1970); Paraná (Azzi \& Dodson, 1971); além do Amazonas, Paraíba, Mato Grosso e Goiás (Gagliumi 1972/1973; Mendes et al., 1977) e Maranhão (Mendonça et al., 1996a).

Embora haja indícios de que estivessem presentes de forma endêmica em canaviais de Sergipe desde 1890 (Guagliumi, 1972/1973), o primeiro relato de ocorrência de cercopídeos radicícolas em cana-de-açúcar, no Brasil, foi feito somente em 1917, quando ataques da cigarrinha-das-raízes foram observados em AngatubaSP. Na época, a espécie em questão foi classificada como T. parana (Moreira, 1921). Novos relatos se sucederam em 1919, referindo-se à espécie T. liturata (Guagliumi, 1968). Em 1921, esta espécie foi encontrada em Leopoldina e São João NeponucenoMG (Moreira, 1925). Em 1924 a ocorrência de T. liturata var. ruforivulata foi mencionada em Campos-RJ; e, em 1945, em diversos municípios do Estado de Sergipe (Veiga, 1964) e Bahia (Caminha Filho, 1945).

Posteriormente, Guagliumi (1969), analisando exemplares de diferentes regiões canavieiras do país, confirmou a presença de $M$. fimbriolata nos Estados do Espírito Santo, Paraná, Santa Catarina e Mato Grosso. Novos relatos de ocorrência se sucederam nos anos de 1986, 1992 e 1996, em Goiás, Alagoas e Maranhão, respectivamente (Mendonça et al., 1996a).

A despeito de estar amplamente disseminada nas principais regiões canavieiras do país, até o início da década de 90 a cigarrinha-das-raízes era considerada praga-chave apenas nos Estados de Sergipe, Bahia e Mato Grosso 
(Mendonça, 1986). Em 1992, tornou-se um dos principais problemas fitossanitários da cana-de-açúcar em Alagoas, após ser introduzida por meio de mudas infestadas de Sergipe (Mendonça, 1996). No entanto, sua importância para a região Centro-Sul do Brasil é mais recente.

\subsection{A cigarrinha-das-raízes, M. fimbriolata, no Estado de São Paulo}

Embora registros históricos comprovem que a cigarrinha-das-raízes, $M$. fimbriolata, está presente nos canaviais paulistas desde o início do século XX (Moreira, 1921), o primeiro relato de prejuízos econômicos causados por esta praga foi em 1971, quando lavouras em Piracicaba-SP foram severamente danificadas (Azzi \& Dodson, 1971). Nesta mesma época, também foram feitos relatos de ataques desta espécie em outras regiões do Estado, causando prejuízos de maior ou menor expressão em função das variedades cultivadas e das condições ambientais, principalmente temperatura e umidade (Botelho et al., 1976; 1977).

Apesar dos prognósticos de que este inseto se tornaria um grave problema para o setor canavieiro na década de 70 , considerando-se a perspectiva de incremento das lavouras irrigadas (Botelho et al., 1976), e da gravidade dos danos sob condições ambientais favoráveis ao seu desenvolvimento, relatos de ataques severos de $M$. fimbriolata continuaram sendo esporádicos (Dinardo-Miranda et al., 1999). Em razão disso, a cigarrinha-das-raízes foi considerada uma praga secundária para a cana-deaçúcar, durante muito tempo (Dinardo-Miranda et al., 2000).

Aparentemente, até meados da década de 90 , as populações de $M$. fimbriolata eram mantidas sob controle, principalmente em função do sistema de colheita por meio da queima do canavial antes do corte ou da palha remanescente após a colheita.

O uso do fogo no canavial limita o crescimento populacional da cigarrinhadas-raízes à medida que provoca a destruição das formas biológicas do inseto, especialmente ovos em diapausa que estão presentes em maior quantidade na época da colheita na região Centro-Sul (Balbo Jr \& Mossim, 1999; Dinardo-Miranda, 1999). Além disso, evita que a palha se acumule no ambiente, mantendo um microclima favorável ao desenvolvimento do inseto (Novaretti et al., 2001). 
A queima do canavial antes da colheita é uma prática tradicional muito utilizada nos países produtores, pois facilita o trabalho de corte, aumentando a eficiência da colheita, e proporciona maior segurança aos trabalhadores envolvidos nesta atividade. Entretanto, tem-se observado uma tendência mundial de eliminação das queimadas como prática de manejo da colheita da cana-de-açúcar (Meyer \& Richard, 1996).

No final da década de 80 , a sociedade civil, grupos ambientalistas e autoridades paulistas iniciaram um movimento exigindo medidas governamentais restritivas para a queima da cana-de-açúcar, em busca de melhorias ambientais e na qualidade de vida nas regiões produtoras. Data de 1988 a Lei $n^{\circ} 6.171 / 88$ que regula a queima da cana no Estado de São Paulo, posteriormente alterada pela Lei $n^{\circ}$ 8.421/93 e regulamentadas pelo Decreto $n^{\circ} 41.719 / 97$ (Gonçalves \& Souza, 1998).

No início da década de 90, a colheita de cana-de-açúcar sem queimar, denominada colheita de cana crua, começou a ser recomendada e, logo em 1994, surgiram os primeiros relatos de áreas com elevadas infestações de M. fimbriolata (Manechini, C., comunicação pessoal).

Em 1997, foi introduzida uma norma específica sobre a queima da cana por meio do Decreto $n^{\circ} 42.056 / 97$, que previa a redução progressiva do uso desta prática, obrigando os produtores de cana-de-açúcar a adotarem o Plano de Eliminação de Queimadas, que ficou conhecido como "PEQ". Nesta época, quase 100\% dos canaviais ainda eram colhidos após a queima da palha (Macedo et al., 1997).

Como o corte manual da cana-de-açúcar sem a queima prévia da palha é uma operação perigosa para os cortadores, por aumentar os riscos de acidentes de trabalho, e antieconômica para os produtores, em função da queda do rendimento de corte e conseqüente aumento nos custos da colheita, houve a necessidade de se investir na mecanização desta operação.

Embora os primeiros estudos tenham se iniciado em 1986, o emprego da colheita mecanizada de cana crua em escala comercial ocorreu somente a partir do início da década de 90. A princípio, a implementação deste sistema foi lenta, mas, dada a necessidade de se cumprir a legislação, a situação se reverteu a partir de 1997. Atualmente, cerca de $27 \%$ da cana produzida no Estado de São Paulo é colhida mecanicamente sem a queima de palha (Paes, L. A. D., comunicação pessoal). 
Neste sistema, a quantidade de matéria seca depositada na superfície do solo após a colheita varia de 8,7 a 15,8 toneladas por hectare, em função da variedade de cana, do estágio de corte e da produtividade agrícola obtida no ciclo da cultura (Centro de Tecnologia Copersucar, 1993). Este material vegetal permanece no ambiente por um longo período e vai se acumulando ao longo dos cortes, já que o processo de decomposição é relativamente lento. Estudos demonstraram que após 335 dias, de 15 toneladas de matéria seca depositadas na superfície do solo durante o processo de colheita, ainda restavam 6 toneladas não decompostas (Abramo Filho, 1995).

Essa drástica mudança no manejo da colheita teve reflexos imediatos nas características do agroecossistema da cana-de-açúcar resultando em alterações no perfil das pragas da cultura, principalmente no que se refere à composição das diferentes espécies e respectivas densidades populacionais (Balbo, 1991; Arrigoni, 1999; Dinardo-Miranda, 2002). O caso que chamou mais a atenção dos produtores foi o da cigarrinha-das-raízes, $M$ fimbriolata, (Dinardo-Miranda et al., 2001), cujas populações aumentaram consideravelmente em muitas regiões (Macedo et al., 1997).

Os principais fatores que beneficiaram o inseto neste novo ambiente foram: aumento significativo da quantidade de raízes superficiais e, portanto, dos locais de alimentação das ninfas; maior proteção das formas imaturas contra o ressecamento; manutenção de temperaturas mais estáveis e elevação da umidade do solo, que favorece consideravelmente seu desenvolvimento (Freire et al., 1968; Botelho et al., 1977; Gallo et al., 2002).

Com a colheita mecanizada de cana crua em franca expansão, os registros de áreas com ataques severos de $M$. fimbriolata se tornaram freqüentes, especialmente nas regiões que apresentavam temperatura e umidade mais elevadas (Dinardo-Miranda et al., 1999a). Com isso, num curto espaço de tempo, a cigarrinha-dasraízes adquiriu o status de praga-chave da cultura e se tornou um dos principais desafios técnicos a ser equacionado nesse sistema de colheita (Macedo et al., 2002). 


\subsection{Descrição e biologia}

A cigarrinha-das-raízes, $M$. fimbriolata, é um inseto hemimetabólico, já que, durante o seu desenvolvimento passa por três estágios biológicos: ovo, ninfa e adulto (Terán, 1987).

\subsubsection{Fase de ovo}

Os ovos são fusiformes, de coloração amarela e medem cerca de $1 \mathrm{~mm}$ de comprimento por $0,25 \mathrm{~mm}$ de largura. O opérculo ocupa aproximadamente um terço do seu comprimento total e se situa na porção anterior, mais afilada (Moreira, 1925). Os ovos, por serem diminutos e depositados em locais protegidos pelas fêmeas, são pouco visíveis no campo (Terán, 1987).

\subsubsection{Fase de ninfa}

As ninfas de $M$. fimbriolata são ditas radicícolas por permanecerem durante todo o período de desenvolvimento se alimentando no sistema radicular de seus hospedeiros. Podem ser encontradas em raízes superficiais e radicelas situadas na base das touceiras, junto às linhas de cana-de-açúcar, (Guagliumi, 1972/1973), em raízes mais profundas, quando existem fendas que permitam que elas se aprofundem no solo (Moreira, 1925; Mariconi, 1963), ou em raízes adventícias ou aéreas da parte inferior dos colmos, em períodos de elevada umidade. Eventualmente se localizam nas entrelinhas de cana, sob o colchão de palha (Mendonça, 1996).

Ao eclodirem, as ninfas medem apenas $1 \mathrm{~mm}$ de comprimento. No final de seu desenvolvimento, após passarem por cinco ínstares, atingem cerca de $10 \mathrm{~mm}$ de comprimento (Moreira, 1925; Mariconi, 1963).

Durante toda a fase ninfal, a cigarrinha-das-raízes, a exemplo de outros cercopídeos, produz e fica envolta em uma densa espuma, formada pela associação de líquidos eliminados pelo ânus e uma substância mucilaginosa secretada por glândulas hipodérmicas localizadas no $7^{\circ}$ e $8^{\circ}$ urômeros, denominadas de glândulas de "Batelli". Estas substâncias adquirem o aspecto característico de espuma pela adição contínua de bolhas de ar que são formadas em um canal respiratório situado na região 
ventral do inseto e distribuídas ao redor do seu corpo por meio de movimentos circulares da extremidade do abdome (Moreira, 1921; Costa Lima, 1942; Borror \& DeLong, 1969; Fewkes, 1969).

A quantidade de espuma produzida pela ninfa é função do volume de seiva retirada da planta (Costa Lima, 1942) e aumenta com o passar dos ínstares (Freire, 1968). Pouco antes da última ecdise, a espuma deixa de ser produzida e começa a secar em virtude da evaporação da porção líquida, formando em seu interior uma cavidade onde a ninfa se transforma em adulto (Costa Lima, 1942).

A importância da espuma para as ninfas de $M$. fimbriolata não foi completamente esclarecida, no entanto, cita-se que sua presença está associada à proteção das ninfas contra a dessecação (Fewkes, 1969; Guagliumi, 1972/1973) e contra o ataque de formigas (Moreira, 1921) e outros inimigos naturais (Caminha Filho, 1945; Guagliumi, 1972/1973). Em alguns casos pode reduzir a eficiência do controle químico por impedir a o contato dos produtos com as ninfas (El-Kadi, 1977).

A ausência de umidade no solo pode comprometer a sobrevivência do inseto, já que em condições de seca a espuma deixa de ser produzida e as ninfas morrem por dessecação (Gallo et al., 2002).

\subsubsection{Fase de adulto}

Os adultos de $M$. fimbriolata medem de 11 a $12 \mathrm{~mm}$ de comprimento e $5 \mathrm{~mm}$ de largura (Guagliumi, 1972/1973), podendo atingir $13 \mathrm{~mm}$ de comprimento por 6,5 mm de largura (Moreira, 1921). Em geral, as fêmeas são maiores que os machos (Guagliumi, 1972-1973).

Existem diferenças na coloração em função do sexo, sendo os machos avermelhados enquanto que as fêmeas, em geral, são mais escuras, apresentando coloração marrom-avermelhada. As tégminas são orladas de preto e apresentam uma faixa longitudinal sinuosa, mais larga na extremidade posterior e da mesma cor. Possuem segmentos abdominais pretos orlados de vermelho e pernas vermelhas (Moreira, 1921; Mariconi, 1963).

Os adultos apresentam ainda, variações cromáticas e no padrão alar dentro do mesmo sexo, relacionados, provavelmente, ao ambiente em que vivem. Essas variações são menos evidentes nas fêmeas (Guagliumi, 1972/1973). 
As pernas posteriores são adaptadas para saltar e as cigarrinhas freqüentemente utilizam este recurso para se deslocarem entre a folhagem, de uma planta para outra, ou quando são molestadas. O vôo que, em geral, é de curta distância (Guagliumi, 1972/1973) está, aparentemente, mais relacionado à dispersão (Mendonça, 1996).

Os adultos vivem na parte aérea da planta e se alimentam sugando seiva das folhas, preferencialmente das folhas apicais (Guagliumi, 1966), e das partes verdes do colmo (Guagliumi, 1972/1973).

Segundo Moreira (1925), os adultos são mais ativos ao entardecer e à noite, permanecendo abrigados nas bainhas foliares ou no cartucho das plantas durante $o$ dia. Entretanto, podem ser encontrados nos períodos mais quentes do dia, saltando entre as folhas da cana. São muito atraídos por luzes artificiais (Guagliumi, 1972/1973).

O acasalamento ocorre a qualquer hora do dia ou da noite (Fewkes, 1969), iniciando algumas horas após a transformação das ninfas em adultos (Freire et al., 1968).

\subsubsection{Ciclo biológico}

$\mathrm{Na}$ época úmida do ano, as fêmeas depositam seus ovos na base das touceiras de cana-de-açúcar, em bainhas secas e outros resíduos vegetais, ou sobre o solo, nas proximidades dos colmos (Guagliumi, 1972/1973). Nas bainhas secas próximas ao solo, principal local de oviposição destes insetos, os ovos são depositados entre as nervuras, próximos da extremidade que adere ao colmo, com o opérculo voltado para o exterior para facilitar a eclosão das ninfas (Freire et al., 1968).

Moreira (1925) determinou que cada fêmea pode produzir até 120 ovos, mas coloca somente ao redor de 8 a 14 ovos, nos primeiros 4 dias após a fecundação. Por outro lado, Freire et al. (1968) verificaram, em média, 50 a 70 ovos/fêmea, com valores máximos de 147 ovos/fêmea em Campos-RJ. Ainda de acordo com estes autores, a postura se inicia 3 a 4 dias após a fecundação, estendendo-se por aproximadamente 10 dias. Em laboratório, sob condições ideais de temperatura, umidade e fotoperíodo, Garcia (2002) obteve uma fecundidade média de 342,1 ovos/fêmea e determinou um período médio de pré-oviposição e oviposição de 5,2 e 16,1 dias, respectivamente. 
O período de incubação em condições normais, ou seja, quando os ovos não entram em diapausa, é de cerca de 15 a 25 dias. Ao eclodirem, geralmente durante a noite ou pela manhã, as ninfas se deslocam em direção às raízes e radicelas da planta e se fixam a elas para sugar a seiva, permanecendo assim durante todo o período ninfal que pode durar de 20 a 70 dias, dependendo das condições microclimáticas do solo. Neste período, as ninfas passam por cinco instares, até se transformarem em adultos (Freire et al., 1968; Guagliumi, 1972/1973; Zucchi et al., 1993; Mendonça, 1996). O período de incubação e a duração da fase ninfal obtidos em laboratório foram, em média, 20,8 e 37,1 dias, respectivamente (Garcia, 2002).

A longevidade média dos adultos varia de 8 a 20 dias, podendo chegar a 23 dias sob condições controladas (Freire et al., 1968; Mendonça, 1996; Garcia, 2002). Em geral, os machos vivem menos que as fêmeas (Garcia, 2002) e as fêmeas fecundadas menos que as fêmeas não fecundadas (Freire et al., 1968). Ainda de acordo com estes autores, em condições de campo, os machos morrem cerca de 3 dias após a cópula.

Segundo Terán (1987), o ciclo biológico completo de M. fimbriolata pode variar de 63 a 79 dias. Entretanto, outros autores mencionam um período superior a 90 dias (Guagliumi, 1972/1973), ou mais curto, entre 30 e 40 dias (Zucchi et al., 1993; Gallo et al. 2002). Em laboratório, a duração média do ciclo de vida variou de 59,3 a 64,9 dias (Garcia, 2002).

\subsection{Injúrias causadas por M. fimbriolata e sintomas de ataque}

\subsubsection{Adultos}

Até recentemente, acreditava-se que os adultos, para se alimentarem, introduziam seu aparelho bucal através da epiderme das folhas, preferencialmente folhas novas (Guagliumi, 1966), atingindo o parênquima externo, região onde se concentram os cloroplastos e aí sugavam seiva (Guagliumi, 1972/1973). Entretanto, estudos sobre o sítio de alimentação da cigarrinha-das-raízes, M. fimbriolata, demonstraram que os adultos introduzem o estilete, preferencialmente, através dos estômatos atingindo o metaxilema nos feixes vasculares, atravessando, portanto, as células do parênquima clorofiliano (Garcia et al, 2004). 
No passado, suspeitava-se que os adultos poderiam inocular algum tipo de patógeno durante o processo de sucção da seiva e que seria a doença por ele provocada responsável pelos prejuízos à cana-de-açúcar (Costa Lima, 1942; El-Kadi, 1977), hipótese esta nunca comprovada. Sabe-se, no entanto, que durante a sucção da seiva, juntamente com a saliva, é injetado um complexo de enzimas e aminoácidos para facilitar o fluxo de seiva ou auxiliar a quebra da sua estrutura, facilitando a assimilação de nutrientes pelo inseto (Guagliumi, 1969; Mendonça, 1996). Estas substâncias têm ação fitotóxica e provocam a destruição de cloroplastos, o entupimento dos vasos do floema e a morte de tecidos (Guagliumi, 1972/1973).

Os sintomas de ataque dos adultos iniciam com o amarelecimento e a necrose dos tecidos no local da picada e adjacências. A partir destes pontos, formamse manchas longitudinais cloróticas que, posteriormente, adquirem uma coloração marrom-avermelhada até se tornarem necróticas, provocando a morte das folhas (Baptista, 1950; Guagliumi, 1966; 1969; 1972/1973). Este processo pode levar de 1 a 3 semanas, em função da quantidade de toxina injetada na folha (Mendonça, 1996).

Quando o número de picadas é muito elevado, a área necrosada evolui rapidamente e as folhas podem secar completamente deixando o canavial com aspecto de queimado, sintoma típico do ataque desta praga (Mendonça, 1996).

A redução da área foliar provoca uma interrupção no fluxo de seiva, interferindo negativamente no processo de fotossíntese. Há uma paralisação parcial das funções vegetativas e uma diminuição da síntese e armazenamento de sacarose no colmo, resultando na redução do desenvolvimento da planta e do teor de sacarose no colmo (Guagliumi, 1966).

\subsubsection{Ninfas}

As ninfas introduzem seu aparelho bucal através da epiderme das raízes e radicelas das plantas, atravessando todo o córtex e atingindo o cilindro vascular de onde extraem seu alimento. Guagliumi (1972/1973) menciona que a sucção de seiva é feita nos vasos lenhosos, porém Garcia et al. (2004) verificaram que ela ocorre nos elementos do tubo crivado do floema primário. A quantidade de seiva extraída varia em função da idade das ninfas e das condições climáticas (Guagliumi, 1972/1973). 
Existem suspeitas de que as ninfas seriam responsáveis pela injeção de substâncias tóxicas nos tecidos da raiz (Costa Lima, 1942; Dantas et al., 1952). Embora este assunto não esteja totalmente esclarecido, atualmente acredita-se que apenas os adultos apresentam esta característica (Guagliumi, 1966; Planalsucar, 1982).

Ao sugarem a seiva, as ninfas causam a deterioração dos tecidos dos vasos condutores, resultando na morte de raízes. O fluxo de água e nutrientes do solo para as partes aéreas da planta é interrompido provocando uma "desordem fisiológica" na planta que, em conseqüência disso, apresenta sintomas de desidratação e desnutrição, ficando com as folhas amareladas e secas. Os entrenós se encurtam e os colmos se tornam finos, ocos e enrugados, murchando do ápice para a base. Numa tentativa de recuperação, a planta emite brotações que também não se desenvolvem. Em alguns casos, pode ocorrer um atraso no desenvolvimento vegetativo e na maturação da cana-de-açúcar (El-Kadi, 1977; Mendonça, 1996).

\subsection{Prejuízos econômicos}

Existem inúmeras publicações que destacam a importância econômica da cigarrinha-das-raízes, M. fimbriolata, para a cana-de-açúcar. Contudo, ainda não está claro se os prejuízos são decorrentes dos danos ocasionados unicamente pelos adultos ou também pelas ninfas e, neste caso, qual seria a participação de cada fase de desenvolvimento do inseto nos prejuízos impostos à cultura.

Segundo Moreira (1925), os prejuízos causados por M. fimbriolata decorrem da sucção de seiva por adultos e ninfas, sendo as ninfas as principais responsáveis pelo definhamento das plantas. Guagliumi (1966; 1969; 1972/1973) argumenta que a quantidade de seiva extraída pelas ninfas seria compensada pelo grande número e extensão das raízes da planta, não afetando significativamente seu desenvolvimento. Acrescenta ainda que os prejuízos causados por este inseto se devem, principalmente, à injeção de substâncias tóxicas pelos adultos durante o processo de sucção da seiva no limbo foliar.

Atualmente, acredita-se que, além dos adultos, em elevadas densidades populacionais, as ninfas são responsáveis por prejuízos consideráveis, em função da mortalidade de raízes que provocam (El Kadi, 1977) e da grande quantidade de seiva 
que retiram das plantas (Terán \& Precetti, 1983; Terán, 1987). Mendonça (1996) afirma que tanto os adultos como as ninfas afetam o desenvolvimento da planta e que ambos seriam responsáveis pelas perdas, mas não estabelece qual a participação de cada fase neste processo.

Os danos causados pela cigarrinha-das-raízes podem ser diretos ou indiretos, quando interferem, respectivamente, na produtividade e na qualidade da matéria-prima.

Os danos diretos são decorrentes do murchamento de colmos, do encurtamento de entrenós, da brotação de gemas laterais e da morte de perfilhos, colmos e até mesmo de touceiras (Moreira, 1921; Guagliumi, 1966; El-Kadi, 1977). Embora possam causar a morte de perfilhos, resultados experimentais evidenciam que o ataque de adultos e ninfas interfere mais no peso da cana do que no seu perfilhamento (Dinardo-Miranda et al., 1999a; Novaretti et al., 2001).

Os danos indiretos resultam da redução da quantidade e qualidade do açúcar recuperável, do aumento do teor de fibra e impurezas, da diminuição da pureza do caldo e da presença de microorganismos que, posteriormente, provocarão contaminações do caldo durante o processo industrial (Macedo et al., 2002).

$\mathrm{O}$ ataque desta praga pode provocar perdas na produtividade agrícola que variam de 15 a $80 \%$, em função da intensidade de infestação, da época de início e duração do ataque, e da fase de desenvolvimento da planta (El-Kadi, 1977), sendo freqüentemente superiores a 40\% (Guagliumi, 1969). Também interfere na qualidade da matéria-prima, com reduções de até 30 \% no teor de sacarose (Guagliumi, 1968; DinardoMiranda et al., 2000).

Ataques severos em canaviais jovens podem causar a morte de touceiras, enquanto que em canaviais em estágio de desenvolvimento mais avançado, as perdas podem atingir até 30\% da produtividade (Planalsucar, 1977).

Em Sergipe, registraram-se prejuízos causados pelo ataque da cigarrinhadas-raízes de aproximadamente $35 \%$ da produção total de açúcar do Estado (Caminha Filho, 1945). Em Campos-RJ, canaviais altamente infestados tiveram sua produção reduzida em 70\% (Souza, 1967).

As estimativas realizadas mais recentemente não diferem muito dos dados mais antigos existentes na literatura, tanto para a região Norte-Nordeste quanto para a 
região Centro-Sul. Nos Estados da Bahia e Sergipe há registros de perdas médias de 30 e 60\%, respectivamente, no período de 1994 a 1996 (Mendonça et al., 1996a).

Observações de campo têm demonstrado que quando os ataques são muito severos as perdas são ainda mais significativas, variando de 30 a 70 t/ha em função do grau de suscetibilidade da variedade cultivada (Dinardo-Miranda, 1999).

Em São Paulo, Dinardo-Miranda et al. (1999a) determinaram reduções de 23,6 a 72\% na produtividade agrícola, em função da variedade cultivada. Ainda de acordo com estes autores, os canaviais colhidos tardiamente são os mais afetados pelo ataque da praga, com perdas médias de $71,42,2$ e 44,8\% para as colheitas realizadas em maio, agosto e outubro, respectivamente.

Dinardo-Miranda et al. (2000a) verificaram que o secamento e a rachadura de colmos, decorrentes do ataque da cigarrinha-das-raízes, provocam alterações na qualidade tecnológica da cana-de-açúcar, resultando em reduções significativas nos teores de sacarose e em incrementos nos valores de fibra.

Em áreas de colheita de cana crua no Estado de São Paulo, Gallo et al. (2002) citam perdas médias da ordem de $11 \%$ na produtividade agrícola e 1,5\% na produção de açúcar, embora em alguns locais as perdas atinjam patamares bem mais elevados.

\subsection{Dinâmica populacional da cigarrinha-das-raízes no Estado de São Paulo}

Os fatores climáticos, principalmente a temperatura e umidade (Freire et al., 1968), influenciam consideravelmente a dinâmica populacional da cigarrinha-dasraízes afetando, diretamente, a duração do seu ciclo de vida e potencial reprodutivo, e indiretamente, a flutuação populacional de seus inimigos naturais (Terán, 1987). A distribuição das chuvas e a duração do período chuvoso são fatores determinantes para o aumento das populações desta praga no campo (Sousa, 1948).

A presença da cigarrinha-das-raízes está intimamente relacionada à ocorrência simultânea de excedente hídrico (Silveira Neto, 1968; Mendes, 1976; Botelho et al., 1977) e temperaturas do solo superiores a $15^{\circ} \mathrm{C}$, fatores que, mantidos por cerca de duas semanas, determinam a quebra da dormência e a eclosão das ninfas a partir dos ovos em diapausa (El-Kadi, 1977). Posteriormente, a dinâmica populacional da praga continua sendo influenciada, predominantemente, por fatores 
climáticos $(80 \%)$, sendo a temperatura do solo o fator de maior importância $(55,9 \%)$ (Mendes, 1977).

No Estado de São Paulo, as infestações se iniciam nos meses de setembro ou outubro com a chegada do período chuvoso, quando a umidade e da temperatura do solo se elevam. A partir dos ovos em diapausa, começam a eclodir as ninfas que darão origem à primeira geração da praga, normalmente, formada por poucos indivíduos. Este processo é gradativo podendo durar mais de 30 dias. A segunda geração se desenvolve nos meses de dezembro e janeiro, sendo de maior magnitude que as demais gerações e a grande responsável pelos prejuízos causados à cultura. $A$ terceira geração, com menor número de ninfas que a anterior, se desenvolve nos meses de fevereiro e março. Os adultos formados neste período colocarão ovos que entrarão em diapausa com a chegada da estação fria e seca (Guagliumi, 1972/1973; El-Kadi, 1977; Almeida, 2001).

$\mathrm{Na}$ estação seca do ano, encontra-se nos canaviais grande quantidade de ovos em diapausa, enquanto que as demais formas biológicas do inseto praticamente desaparecem em função das condições climáticas adversas (Azzi \& Dodson, 1971) e do aumento da atividade dos inimigos naturais (El-Kadi, 1977).

\subsection{Monitoramento de populações da cigarrinha-das-raízes em cana-de-açúcar}

Atualmente existe um consenso de que o sucesso no controle da cigarrinhadas-raízes, independentemente da estratégia adotada, está condicionado à detecção da primeira geração da praga no campo (Guagliumi, 1966; Mendonça, 1996; Almeida, 2001), já que a população cresce em progressão geométrica, atingindo patamares elevados na segunda geração (El-Kadi, 1977).

Sendo assim, o acompanhamento da população da cigarrinha-das-raízes, a partir do momento em que as condições climáticas se tornam favoráveis à eclosão das ninfas, é ponto chave para seu manejo. Contudo, por ser formada por poucos indivíduos e não causar prejuízos econômicos significativos à cana-de-açúcar, a primeira geração pode passar despercebida, caso não se adote um sistema eficiente de monitoramento de populações (Guagliumi, 1972/1973).

Os levantamentos devem ter início com a chegada da estação chuvosa e aumento das temperaturas, ocasião em que se encerra o período de diapausa e as 
ninfas começam a eclodir, e ser mantidos durante todo o período de ocorrência do inseto no campo, ou seja, até a chegada da estação seca (Mendonça, 1996).

O monitoramento de $M$. fimbriolata pode ser realizado por meio da captura de adultos em armadilha luminosa (Ribemboim, 1967; Silveira Neto et al., 1968; Botelho et al., 1977); armadilhas de coloração amarela, confeccionadas em material plástico impregnado com uma substância adesiva (cola), nas duas faces (Almeida, 2001) ou pela contagem direta de adultos e ninfas, nas folhas e no solo (Guagliumi, 1972/1973; Mendonça et al., 1996a; Almeida, 2001).

Grisoto \& Garcia (2003) avaliaram a eficiência de captura de adultos em armadilhas amarelas adesivas posicionadas em diferentes alturas $(0,5$ a $2 \mathrm{~m}) \mathrm{e}$ concluíram que elas devem ser instaladas a $0,5 \mathrm{~m}$ do solo, já que, nesta altura, as coletas representaram $74,2 \%$ do total de adultos capturados.

Analisando-se a atratividade dos diferentes tipos de armadilhas, em função do sexo da cigarrinha-das-raízes, verifica-se que os machos são significativamente mais atraídos pela luz do que as fêmeas, representando $75 \%$ do total de adultos capturados por armadilhas luminosas (Guagliumi, 1971). Nas armadilhas amarelas adesivas, a captura restringe-se quase exclusivamente aos machos (Stingel E., dados não publicados).

Apesar de as armadilhas luminosas e amarelas adesivas serem eficientes na captura de adultos da cigarrinha-das-raízes, $M$. fimbriolata, até o momento não se dispõe de dados confiáveis para o seu uso como método de monitoramento em programas de manejo desta praga.

Nesse sentido, a contagem de formas biológicas de $M$. fimbriolata, nas folhas e no solo, tem sido o sistema de monitoramento mais freqüentemente empregado pelos produtores de cana-de-açúcar em áreas afetadas por esta praga no Brasil.

Segundo Guagliumi (1972/1973), para se obter uma boa precisão na estimativa do grau de infestação da praga deve-se fazer a contagem do número de adultos nas folhas e de ninfas na base das touceiras, após a remoção da palha, em 5 pontos distribuídos dentro da área de cada talhão. Em cada ponto, devem ser examinadas 10 touceiras, o que corresponde a aproximadamente 500 canas.

Mendonça et al. (1996a) recomenda a realização da contagem de formas biológicas em 4 pontos de 2,5 metros lineares por talhão de até 5 hectares, distribuídos 
ao acaso na área a ser monitorada. Este autor afirma ainda que a amostragem pode ser reduzida a apenas 1 ponto de 2,5 metros lineares por talhão quando a população se distribui uniformemente na área. Em cada ponto deve ser feita a contagem do número de adultos nas folhas e no cartucho das plantas e do número de colmos. Após a remoção da palha das linhas e entrelinhas da cana-de-açúcar, faz-se a contagem do número de espumas e de ninfas na base das touceiras, ao nível do solo.

Almeida (2001), por sua vez, sugere que a contagem de ninfas em 3 a 5 pontos por hectare, sendo cada ponto representado por 2 metros lineares.

A recomendação do Centro de Tecnologia Canavieira (CTC) é que o monitoramento de populações seja feito em 16 metros lineares por hectare, divididos em 4 pontos de amostragem e distribuídos de maneira uniforme na área a ser amostrada. Cada ponto corresponde a 4 metros lineares, representados por 2 sulcos paralelos de 2 metros lineares. Em cada ponto, contam-se o número de adultos vivos e mortos nas folhas e, após o afastamento da palha, $0,5 \mathrm{~m}$ de cada lado das linhas de cana, o número de espumas, ninfas e adultos no solo. Durante o levantamento, anotam-se as formas biológicas vivas, infectadas por fungos ou mortas (Arrigoni, E.D.B., comunicação pessoal).

Considerando-se que a eficiência das medidas de controle é maior quando estas são aplicadas sobre a primeira geração da praga e que o controle de ninfas deverá ser sempre priorizado em relação ao controle de adultos (Mendonça, 1996), a contagem direta de formas biológicas é o método de monitoramento mais indicado para o desenvolvimento de um programa de manejo integrado desta praga, ao menos no início das infestações.

A despeito da importância de se adotar um método de amostragem único para M. fimbriolata, para evitar os seus danos econômicos e desenvolver estratégias eficientes de controle, na prática, verifica-se que não existe uma padronização na metodologia de amostragem empregada pelos produtores, havendo variações significativas quanto ao tamanho da unidade de amostra, ao número de pontos de amostragem por unidade de área e à distribuição dos pontos amostrais na área a ser monitorada. 


\subsection{Nível de Dano Econômico (NDE) e Nível de Controle (NC)}

O conhecimento do Nível de Dano Econômico (NDE) e do Nível de Controle (NC) é um fator chave para a tomada de decisão em um programa de manejo integrado de pragas. Entretanto, até o momento, estes parâmetros não foram cientificamente determinados para a cigarrinha-das-raízes, $M$. fimbriolata, em cana-deaçúcar. Ainda assim, estes índices têm sido propostos e empregados empiricamente.

Segundo Guagliumi (1972/1973), medidas de controle devem ser adotadas quando forem encontrados entre 1 e 2 adultos por cana. Mendonça (1996), cita como $\mathrm{NC}$, a presença de 4 a 12 ninfas por metro linear de sulco, e de 0,5 a 0,75 adulto por cana, e como NDE, 20 ninfas por metro linear de sulco e 1 adulto por cana.

De acordo com Almeida (2001), para o Estado de São Paulo, adota-se como NC 3 a 4 ninfas por metro linear e como NDE 8 a 10 ninfas por metro linear. A recomendação do CTC é que medidas de controle sejam implementadas quando a densidade populacional atingir o limite de 5 ninfas por metro linear (Arrigoni, E.D.B., comunicação pessoal).

Novaretti et al. (2001) propõem que se utilizem diferentes valores de NC para o Estado de São Paulo, de acordo com a época de ocorrência da praga no campo. Segundo esses autores, o NC é 4 a 5 ninfas ou 0,5 adulto por metro linear, nos meses de outubro e novembro, 8 a 10 ninfas ou 3 adultos por metro linear, nos meses de dezembro e janeiro, e 15 a 17 ninfas ou 8 adultos por metro linear, nos meses de fevereiro e março.

$\mathrm{Na}$ prática, assim como no monitoramento, verifica-se que não existe um consenso entre pesquisadores no sentido de adotarem um NC padrão para a cigarrinha-das-raízes, $M$. fimbriolata, em cana-de-açúcar. Em conseqüência disso, cada produtor tem utilizado o NC que julga ser mais conveniente. 


\subsection{Aspectos teóricos relacionados aos planos de amostragem}

Para monitorar a população de uma praga é necessário que se desenvolva um plano de amostragem, e que este processo seja fundamentado em princípios básicos de estatística e no conhecimento da distribuição espacial, do ciclo de vida e do comportamento do inseto (Southwood, 1978). Segundo Wilson (1985), o conhecimento do modelo de distribuição espacial ou probabilístico de um inseto é primordial para o desenvolvimento de um plano de amostragem em sistema de culturas agrícolas.

Três tipos básicos de distribuição descrevem os arranjos espaciais ocupados pelos insetos na natureza: ao acaso ou aleatória, regular ou uniforme e agregada ou contagiosa (Rabinovich, 1980). De acordo com a distribuição espacial, métodos diferentes de amostragem são necessários, variando-se o número, o tamanho da unidade amostral e a forma como estas amostras são tomadas na área (Morisita, 1959). Portanto, o conhecimento da distribuição do inseto no campo é fundamental para o estabelecimento de um plano de amostragem (Norris et al., 2001), já que ela afeta significativamente a precisão da amostragem (Kogan \& Herzog, 1980).

Após a definição do modelo de distribuição espacial do inseto no campo, as etapas subseqüentes para o desenvolvimento de um plano de amostragem são: determinação do tamanho da unidade amostral, do número de amostras necessárias para estimar a população real com a precisão desejada, e como as amostras serão tomadas na área (ao acaso, estratificada ou sistemática).

Os fatores que podem interferir na eficiência de uma amostragem são: a disposição espacial dos indivíduos, a variação populacional no tempo, os efeitos provocados por diferentes dispositivos de coleta e a subjetividade do amostrador (Rabinovich, 1980). Deve-se ainda considerar a questão econômica, pois nenhum plano de amostragem, por mais eficiente que seja, será aceito se não for economicamente viável (Sterling et al., 1983; Wilson et al., 1989). Além disso, a amostragem deve ser rápida e de fácil execução (Flint \& van den Bosh, 1981).

Ao se estabelecer um plano de amostragem, dois aspectos devem ser analisados: a acurácia e a precisão. O primeiro reflete quanto o resultado obtido se aproxima da população real presente na área, enquanto o segundo refere-se à constância da variação, que permite estimar o erro da amostragem. O nível de acurácia exigido varia em função do propósito da amostragem. Elevada acurácia é 
necessária quando o objetivo é estimar a população em um trabalho científico. Em contrapartida, se o objetivo é a tomada de decisão em programas de manejo integrado, deve-se buscar um equilíbrio entre o nível de precisão do plano de amostragem e o seu custo. Portanto, o plano de amostragem deve ser economicamente exeqüível e os resultados que ele proporciona estatisticamente confiáveis (Norris et al., 2001).

A comparação estatística de diferentes planos de amostragem quanto à precisão é normalmente feita com base na Variação Relativa dos dados obtidos. Entretanto, quando o custo é levado em consideração, muitos autores utilizam a Precisão relativa (Southwood, 1978) 


\section{MATERIAL E MÉTODOS}

O estudo foi desenvolvido no período de outubro de 2003 a setembro de 2004, em canaviais infestados pela cigarrinha-das-raízes da cana-de-açúcar, Mahanarva fimbriolata (Stål, 1854). Os experimentos foram conduzidos em áreas das Usinas São Luiz S.A. e São Martinho, situadas, respectivamente, em Ourinhos-SP (latitude $22^{\circ} 58^{\prime} 28^{\prime \prime} \mathrm{S}$; longitude 4952' 19" W ) e Guariba-SP (latitude $21^{\circ} 22^{\prime} 30^{\prime \prime} \mathrm{S}$; longitude $48^{\circ} 13^{\prime} 00^{\prime \prime} \mathrm{W}$ ), representando duas regiões produtoras de cana-de-açúcar com características climáticas diferentes.

\subsection{Critérios de seleção e descrição das áreas experimentais}

Os locais selecionados para a instalação dos experimentos apresentavam as seguintes características: (i) colheita dos dois últimos cortes realizada com colhedoras mecânicas, sem a queima prévia do canavial ou da palha remanescente, após o corte; (ii) sulcos de plantio retos para que os pontos de amostragem demarcados em cada linha ficassem distribuídos paralelamente entre si; (iii) boa uniformidade na população de plantas e com falhas de brotação nunca superiores a $1 \mathrm{~m}$ linear; (iv) distribuição uniforme da palha na superfície do solo; (v) cultivado com variedade suscetível ao ataque da praga e amplamente difundida no Estado de São Paulo; (vi) histórico de infestações pela cigarrinha-das-raízes, confirmado por meio de levantamentos populacionais; e (vii) ausência ou baixa incidência de outras pragas comuns à cultura.

Em Ourinhos instalaram-se três experimentos, sendo dois na Fazenda Bela Vista, talhão 33, e um na Fazenda Água Suja, talhão 35, que apresentam, respectivamente, solos caracterizados como Latossolo Vermelho eutroférrico e Latossolo Vermelho distroférrico (Embrapa, 1999).

Na Fazenda Bela Vista, o plantio foi feito em janeiro de 1999, utilizando-se a variedade RB855536 e o espaçamento de 1,5 m entre linhas. O primeiro corte da área 
foi realizado de forma manual após a queima do canavial em 20/05/2000. As colheitas do segundo, terceiro e quarto cortes do canavial foram realizadas por colhedoras mecânicas, sem a queima prévia da palha, em 14/10/2001, 09/09/2002 e 24/08/2003, respectivamente.

Na Fazenda Água Suja o plantio foi feito em fevereiro de 2000, utilizando-se a variedade SP81-3250, no espaçamento de 1,5 m entre linhas. As colheitas do primeiro, segundo e terceiro cortes do canavial foram feitas mecanicamente, sem a queima prévia do canavial, em 22/06/2001, 11/06/2002 e 15/07/2003, respectivamente.

Em Guariba, instalou-se apenas um experimento na Fazenda Bibiana, gleba 5232, quadra 3, que apresenta solo caracterizado como Latossolo Vermelho eutrófico (Embrapa, 1999).

O plantio da área foi feito em janeiro de 2001, utilizando-se a variedade SP87-365 e o espaçamento de 1,5 m entre linhas. As colheitas do primeiro e segundo cortes foram feitos mecanicamente, sem a queima prévia do canavial, em 29/11/2002 e 08/10/2003, respectivamente.

Após a última colheita das áreas onde se instalaram os experimentos, foi feita a fertilização do canavial distribuindo-se o adubo na superfície do solo, sem sua posterior incorporação ao solo. Durante todo o ciclo de desenvolvimento da cana, não se realizou nenhuma operação agrícola que pudesse alterar o padrão de distribuição da palha na superfície do solo ou interferir na dispersão dos insetos na área experimental, tais como: aleiramento de palha, afastamento de palha das linhas de cana e cultivo mecânico da soqueira. Também não se implementou nenhuma medida de controle da cigarrinha-das-raízes nas áreas experimentais e adjacentes.

\subsection{Estudo da distribuição espacial e plano de amostragem}

Para a realização deste estudo foram instalados dois experimentos, sendo um na Fazenda Bela Vista, em Ourinhos-SP, e outro na Fazenda Bibiana, em GuaribaSP. 


\subsubsection{Instalação dos experimentos}

Cada experimento foi constituído de três parcelas retangulares, de 60 linhas de cana com $120 \mathrm{~m}$ de comprimento, correspondendo a uma área de aproximadamente 1,1 ha.

As parcelas foram demarcadas em local determinado ao acaso no talhão, distanciadas, por no mínimo $15 \mathrm{~m}$ dos carreadores principais para evitar o "efeito bordadura". Foram também isoladas do restante da área do talhão por aceiros obtidos rebaixando-se 2 linhas de cana de cada lado, no sentido do sulco, e demarcando-se um carreador de $2 \mathrm{~m}$ perpendicular às linhas.

No interior das parcelas foram feitas marcações utilizando-se piquetes de eucalipto numerados para facilitar a localização dos pontos de amostragem. A cada duas entrelinhas de cana, colocaram-se 10 piquetes em intervalos de $12 \mathrm{~m}$, no sentido dos sulcos de plantio, servindo de referência para duas linhas de cana.

\subsubsection{Metodologia de avaliação}

Os experimentos foram avaliados em três épocas distintas: outubronovembro em 2003, janeiro-fevereiro e março-abril em 2004, sendo cada parcela amostrada em uma época, definida ao acaso.

Para a determinação do momento mais adequado para a realização das amostragens, dentro das épocas pré-determinadas, foi feito o acompanhamento da dinâmica populacional de adultos e ninfas da cigarrinha-das-raízes nas duas propriedades, a partir do mês de outubro de 2003.

Em Guariba, a definição da data de amostragem de cada parcela foi baseada em levantamentos quinzenais realizados nas bordaduras da área experimental, seguindo a metodologia recomendada pelo Centro de Tecnologia Canavieira (vide item 2.9). Em Ourinhos, utilizaram-se os dados obtidos no experimento para avaliação da eficiência do método de amostragem comercial, instalado na mesma propriedade.

Considerou-se como momento ideal de amostragem o pico populacional de ninfas, a cada geração da praga, de forma que diferentes níveis de infestação fossem avaliados. 
Após a definição da data de amostragem, foram avaliados 60 pontos de $1 \mathrm{~m}$ linear em cada linha da parcela. A cada intervalo de $12 \mathrm{~m}$, demarcado por piquetes, avaliou-se 6 pontos espaçados de $1 \mathrm{~m}$ linear a partir do piquete inicial, de maneira que ficassem uniformemente distribuídos. Em cada parcela foram amostrados 3.600 pontos, o que equivale a $50 \%$ da área demarcada (Figura 1).

Quando se constatava a presença de falhas de brotação no local onde seria realizada a avaliação, o ponto de amostragem era deslocado $1 \mathrm{~m}$ adiante, retornando ao local pré-estabelecido no ponto seguinte.

A padronização da área de cada ponto de amostragem foi obtida por gabaritos construídos com tubos de PVC em forma de retângulo com dimensões de $1 \mathrm{x}$ $0,5 \mathrm{~m}$, sendo um dos lados abertos, para facilitar seu posicionamento no solo.

A seqüência de amostragem utilizada foi: (i) demarcação do ponto de amostragem com os gabaritos; (ii) remoção de toda palha da base das touceiras com cuidado para não arrastar formas biológicas do inseto; e (iii) contagem direta do número de adultos e ninfas de $M$. fimbriolata presentes na base das touceiras, ao nível do solo (Figura 2). 


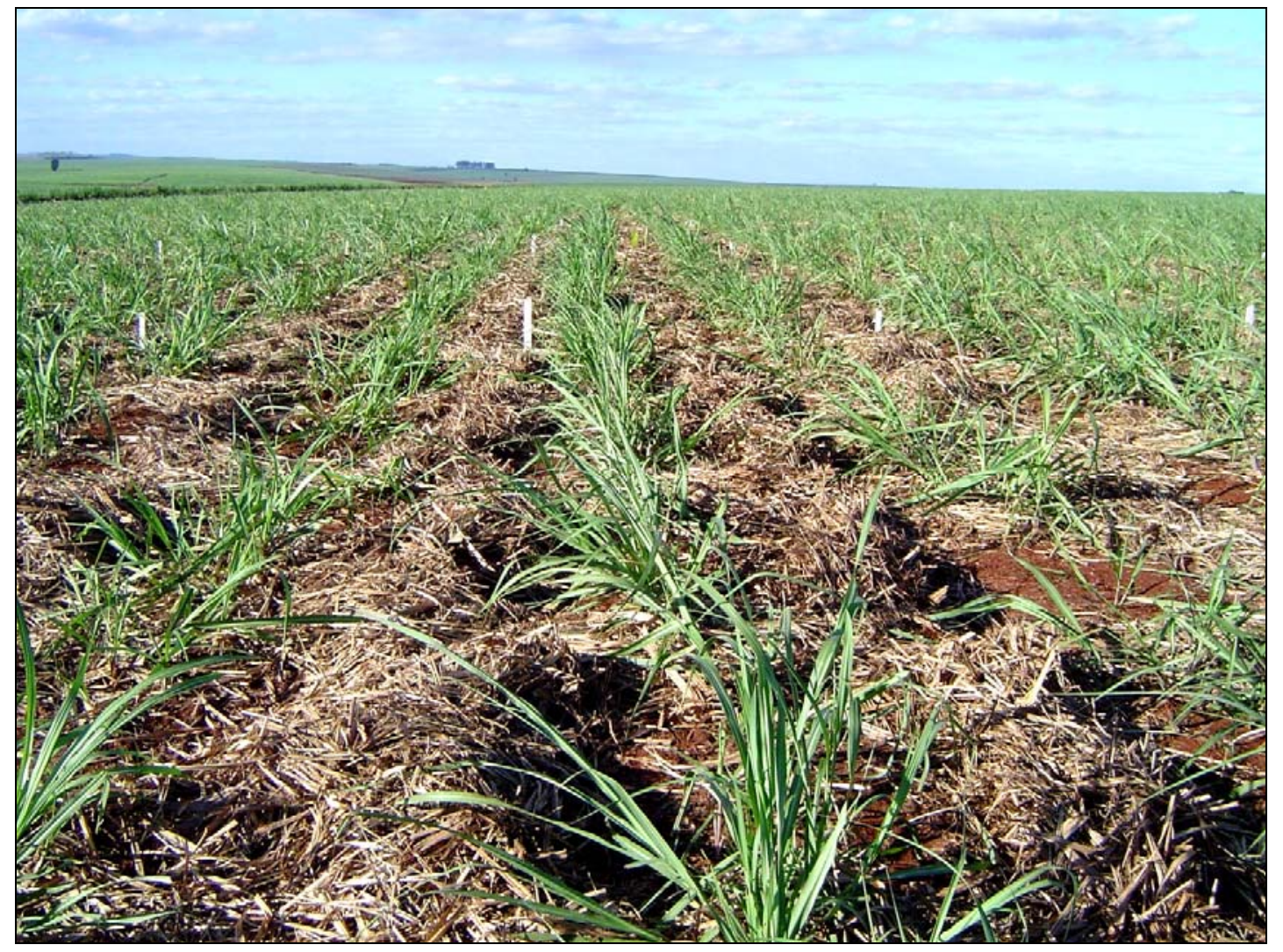

Figura 1 - Distribuição dos pontos de amostragem na parcela do experimento conduzido em Ourinhos-SP, após a avaliação realizada em 29/10/2003 

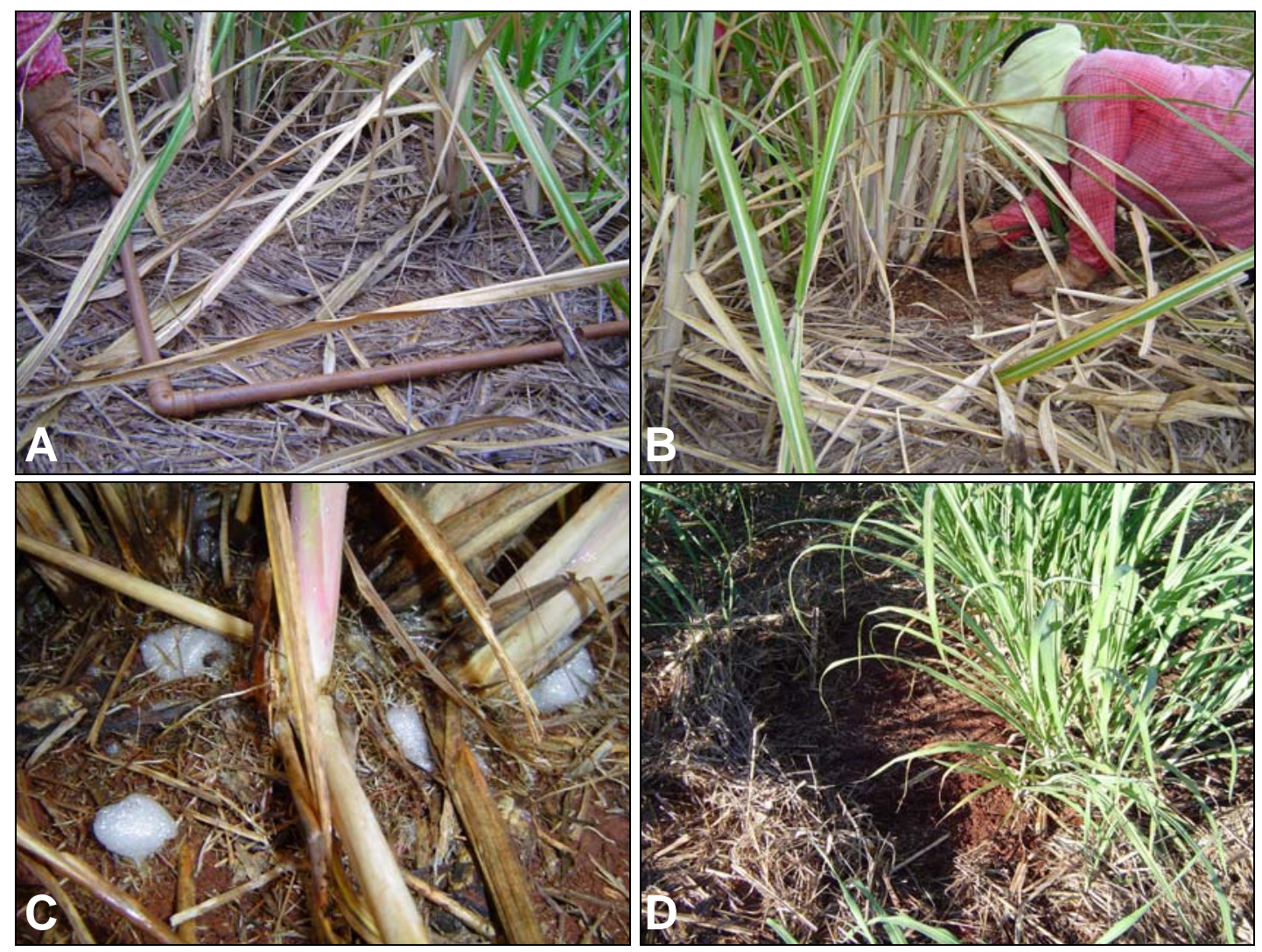

Figura 2 - Método de amostragem utilizado para Mahanarva fimbriolata em cana-deaçúcar: demarcação do ponto de amostragem com gabaritos $(A)$; remoção da palha da base das touceiras (B); contagem de formas biológicas da cigarrinha-das-raízes ao nível do solo $(C)$ e aspecto geral do ponto de amostragem após o levantamento (D) 


\subsubsection{Análise dos dados}

O modelo de distribuição espacial da cigarrinha-das-raízes, M. fimbriolata, na cultura da cana-de-açúcar foi determinado para cada um dos parâmetros: número de adultos e ninfas presentes no solo, época de amostragem, e local; utilizando-se o índice de Morisita $\left(I_{\delta}\right)($ Morisita $1959 ; 1962)$, descrito a seguir:

$$
\begin{aligned}
& I_{\delta}=n \frac{\sum x^{2}-\sum x}{\left(\sum x\right)^{2}-\sum x} \quad \text { sendo; } \\
& n \text { - número total de amostras } \\
& \sum x \text { - somatório do número de indivíduos nas amostras }
\end{aligned}
$$

A significância do desvio do valor do $I_{\delta}$ em relação à unidade foi obtida por meio do teste $F(P \leq 0,05)$, para o valor obtido na fórmula:

$$
F_{0}=\frac{I_{\delta}\left(\sum x-1\right)+n-\sum x}{n-1} \quad \text { sendo; }
$$

$I_{\delta}$ - índice de Morisita

$n$ - número total de amostras

$\sum x$ - somatório do número de indivíduos nas amostras 
Para o modelo de distribuição binomial negativa, proposto por Bliss \& Fisher (1953), foi calculado o índice de dispersão (k), pelo método dos momentos (Ascombe, 1949; 1950):

$$
\begin{aligned}
& k=\frac{\bar{x}^{2}}{s^{2}-\bar{x}} \text { onde, } \\
& \bar{x} \text { - número médio de indivíduos nas amostras } \\
& s^{2} \text { - variância }
\end{aligned}
$$

A partir do valor de $\mathrm{k}$ inicial, foi utilizado o método da máxima verossimilhança, desenvolvido por Fisher (Bliss \& Fisher, 1953), para determinação do $\mathrm{k}$ ideal. Utilizaram-se dois tipos de fórmulas interativas, selecionadas de acordo com a freqüência de amostras que apresentaram valores nulos.

A estimativa do número ideal de amostras foi feita, para diferentes níveis de precisão (15 a 50\%), utilizando-se a fórmula proposta para quando a distribuição espacial do inseto é agregada (Kogan \& Herzog, 1980):

$n=\frac{\left[\frac{1}{\bar{x}}+\frac{1}{k}\right] t^{2}}{E^{2}}$ sendo;

$k$ - índice de dispersão (k ideal)

$\bar{X}$ - número médio de indivíduos nas amostras

$E$ - nível de precisão (relação entre o erro padrão da média e a média)

$t$ - valor do teste "t" $(\mathrm{P} \leq 0,05)$

Utilizando-se mapas de distribuição da população no campo, elaborados com os dados reais obtidos nos experimentos, realizaram-se simulações de amostragens, avaliando-se diferentes combinações de tamanho de amostras e esquemas de caminhamento (Figura 3). 
O plano de amostragem mais adequado para avaliação da população da cigarrinha-das-raízes em cana-de-açúcar foi determinado com base no intervalo de confiança $(P \leq 0,05)$ da média para a Variação Relativa $(V R)$ e Precisão Relativa $(P R)$ (Kogan \& Herzog, 1980), obtida para cada simulação de amostragem.

A Variação Relativa (VR) é dada por:

$V R=\frac{100 s(\bar{x})}{\bar{X}} \quad$ sendo;

$s(\bar{x})$ - erro padrão da média

$\bar{X}$ - número médio de indivíduos nas amostras

A Precisão Relativa (PR) dada por:

$P R=\frac{100}{V R \cdot C_{a}} \quad$ sendo;

VR - Variação Relativa

$C_{a}$ - tempo gasto na amostragem (hora-homem)

Como o cálculo da Precisão Relativa (PR) leva em consideração o custo de realização da amostragem e o seu principal componente é a mão-de-obra, utilizou-se o tempo gasto na amostragem por meio de um coeficiente hora-homem, para cada combinação de número de amostra e caminhamento. A estimativa deste coeficiente foi feita considerando-se 2 minutos para a tomada de cada amostra e uma velocidade média de deslocamento no canavial de $0,8 \mathrm{~m} / \mathrm{s}$. 
Esquema A

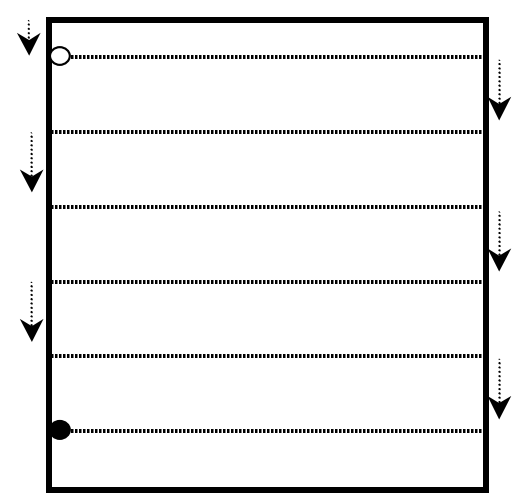

Esquema C

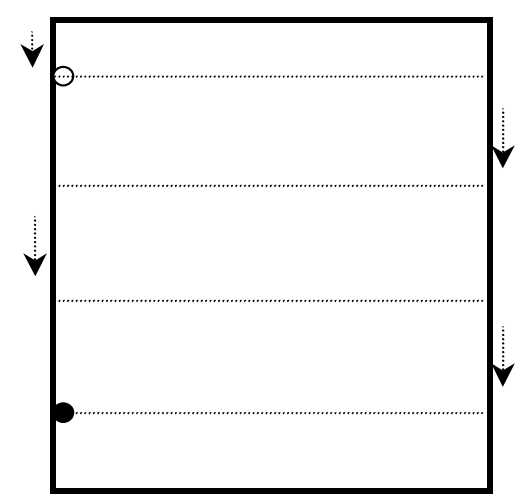

Esquema $\mathrm{E}$

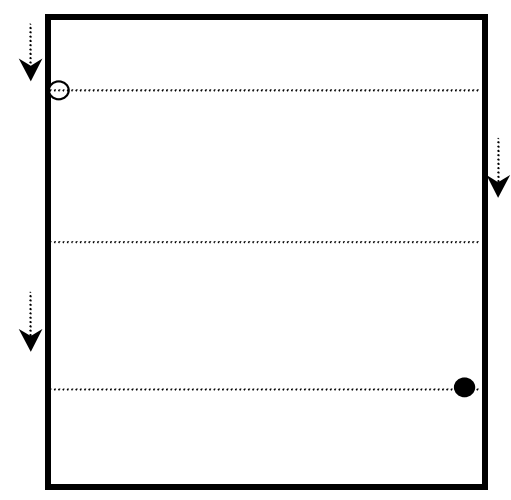

Esquema B

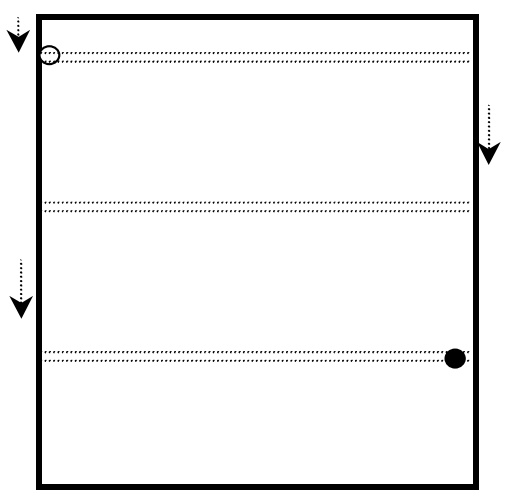

Esquema D

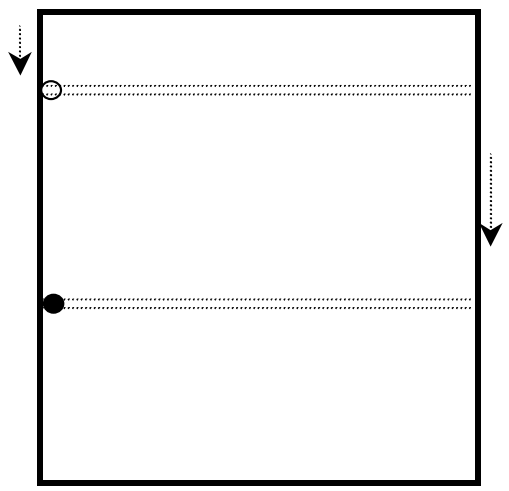

Esquema $\mathrm{F}$

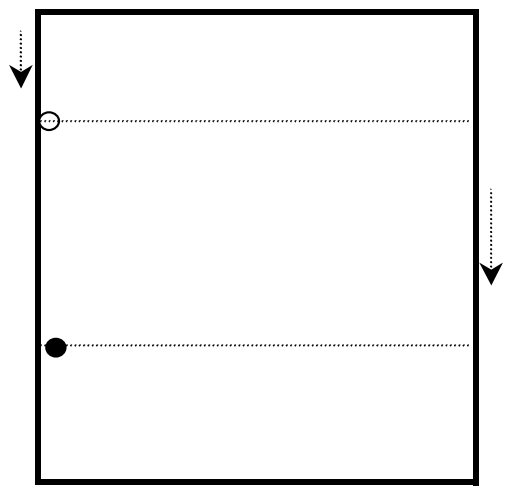

Figura 3 - Esquemas (A, B, C, D, E, e F) de caminhamento propostos para amostragem da população de ninfas da cigarrinha-das-raízes, Mahanarva fimbriolata, em cana-de-açúcar 


\subsection{Avaliação do sistema de amostragem comercial}

Os experimentos foram instalados nas fazendas: Bela Vista e Água Suja, ambas localizadas em Ourinhos-SP e distantes cerca de $20 \mathrm{~km}$ entre si, em setembro de 2003.

\subsubsection{Instalação dos experimentos}

Em cada talhão selecionado foi demarcada uma parcela retangular composta de 60 linhas de cana de $120 \mathrm{~m}$ de comprimento.

A parcela foi inserida em local determinado ao acaso no talhão de cana-deaçúcar a uma distância mínima de $40 \mathrm{~m}$ dos carreadores, para evitar o "efeito bordadura", e isolada do restante da área do talhão por aceiros, rebaixando-se 2 linhas de cana de cada lado, no sentido do sulco, e demarcando-se um carreador de $2 \mathrm{~m}$ perpendicular às linhas.

No interior da parcela, os pontos de amostragem foram previamente demarcados com estacas de bambu de $50 \mathrm{~cm}$ de altura, distanciadas $1 \mathrm{~m}$ entre si, em todas as linhas (Figura 4). Para facilitar a localização dos pontos de amostragem, a cada duas entrelinhas de cana, colocaram-se 5 piquetes de eucalipto em intervalos de $24 \mathrm{~m}$, no sentido dos sulcos de plantio, servindo de referência para duas linhas de cana. 


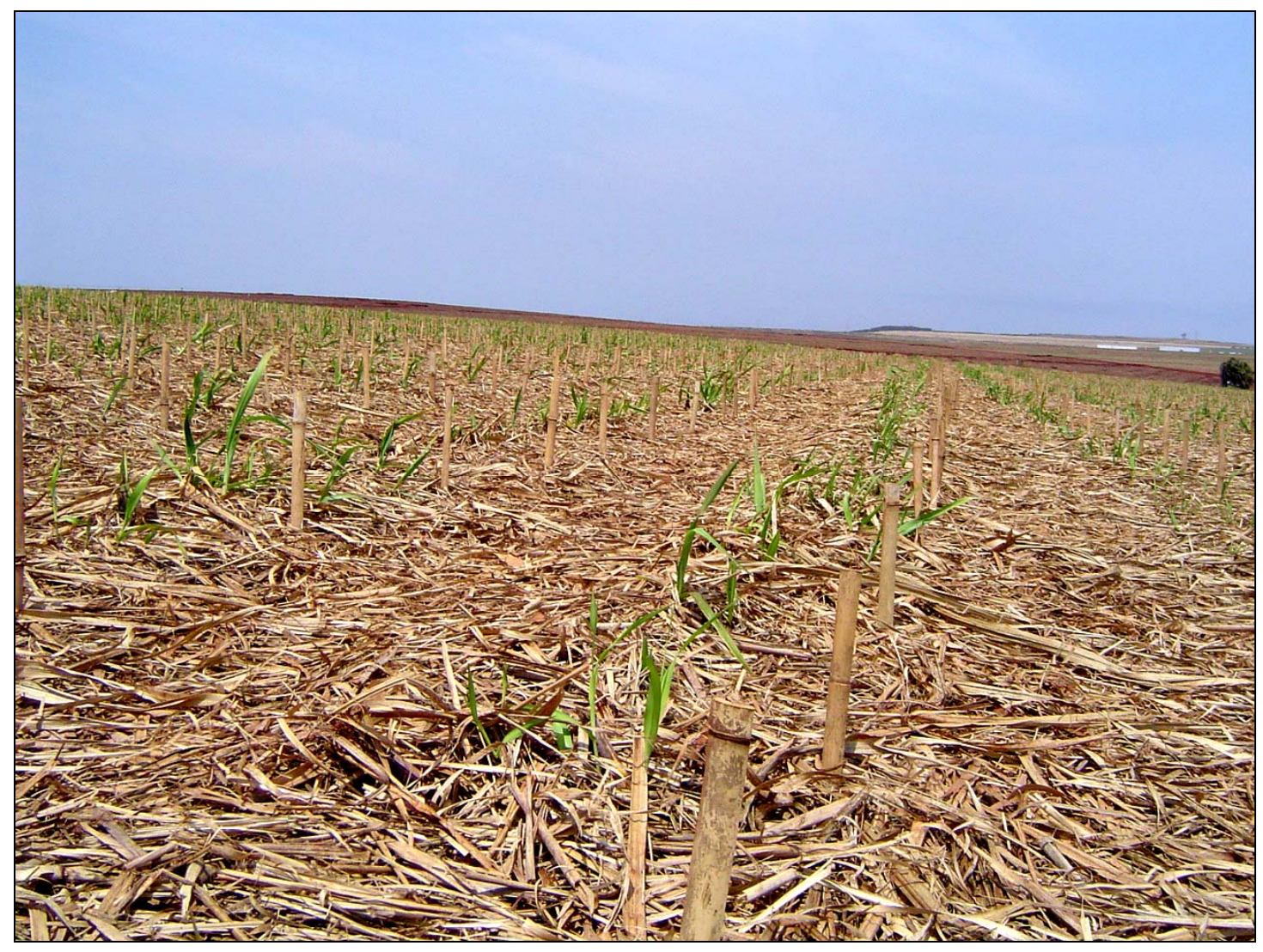

Figura 4 - Demarcação dos pontos de amostragem na parcela do experimento para avaliação do sistema de amostragem comercial da cigarrinha-das-raízes, Mahanarva fimbriolata, em cana-de-açúcar 


\subsubsection{Metodologia de avaliação}

Os experimentos foram avaliados em intervalos de aproximadamente 15 dias, em função da disponibilidade de mão-de-obra e condições climáticas, durante o período de um ano, entre outubro de 2003 e setembro de 2004.

Em cada avaliação, foram realizadas amostragens na parcela, denominadas amostragens experimentais (AE), e no restante do talhão onde a parcela estava inserida, as amostragens comerciais (AC).

$\mathrm{Na}$ parcela, em cada levantamento, amostravam-se cinco pontos de $1 \mathrm{~m}$ linear em todas as linhas, totalizando 300 pontos. A cada intervalo de $24 \mathrm{~m}$, demarcados por piquetes, avaliava-se 1 ponto.

$\mathrm{Na}$ primeira avaliação, a amostragem foi feita no primeiro ponto a partir dos piquetes de referência. Nas demais avaliações, a amostragem foi realizada na seqüência dos pontos amostrados na quinzena anterior, mantendo-se a mesma distribuição dos 300 pontos ao longo dos levantamentos.

O método de amostragem empregado na parcela, tanto para adultos como para ninfas no solo, foi o mesmo descrito no item 3.2.2. Além destes parâmetros, foi feita a contagem direta de adultos nas folhas e a contagem do número de espumas, para avaliar sua relação com o número de ninfas. O critério utilizado na contagem de espumas foi que as mesmas só seriam contadas separadamente se não tivessem nenhum ponto de contato entre si, caso contrário, eram consideradas como uma única espuma.

No mesmo dia da avaliação da parcela foi feita a amostragem comercial no restante do talhão, utilizando-se a metodologia recomendada pelo Centro de Tecnologia Canavieira (CTC), que consiste na contagem de formas biológicas em $16 \mathrm{~m}$ lineares/ha, divididos em 4 pontos, distribuídos na área de maneira uniforme. Cada ponto corresponde a $4 \mathrm{~m}$ lineares, representados por 2 sulcos paralelos de $2 \mathrm{~m}$ lineares. Os parâmetros populacionais avaliados foram os mesmos das parcelas. Esta metodologia de amostragem foi escolhida para o experimento por ser a que recomenda maior tamanho de amostra e maior unidade de amostra. 


\subsubsection{Análise de dados}

Para avaliação da precisão e acurácia do sistema de amostragem comercial, os índices de infestação de adultos e ninfas de $M$. fimbriolata, apurados em cada época de levantamento, foram comparados com os dados da amostragem experimental, utilizando-se o método gráfico (curvas de flutuação populacional) (Kogan \& Herzog, 1980) e análise de regressão linear.

A possibilidade de se estimar o número de ninfas por meio da contagem de espumas na base das touceiras de cana-de-açúcar foi avaliada utilizando-se análise de regressão linear para estudar a relação entre o número médio de espumas e ninfas encontradas em cada avaliação, na AC e AE, nas duas propriedades. 


\section{RESULTADOS E DISCUSSÃO}

\subsection{Estudo do modelo de distribuição espacial e plano de amostragem}

\subsubsection{Modelo de distribuição espacial de ninfas}

As contagens de ninfas de Mahanarva fimbriolata (Stål., 1854), realizadas em Ourinhos e Guariba-SP, demonstram que as áreas experimentais apresentaram índices máximos de infestação muito próximos entre si (Tabela 1). Contudo, os índices de infestação apurados em Guariba, na primeira e terceira épocas, foram inferiores aos de Ourinhos. Isto pode ter ocorrido por várias razões como o mês de colheita do canavial, as condições climáticas durante o período de ocorrência da praga no campo, a ação de inimigos naturais e, até mesmo, a época definida para a realização da amostragem.

Em Ourinhos, a população de ninfas da cigarrinha-das-raízes, M. fimbriolata, apresentou um número pequeno de indivíduos na primeira geração, aumentando significativamente até atingir o pico na segunda geração, seguida de uma queda na terceira geração. Em Guariba, o crescimento da população de ninfas foi semelhante ao observado em Ourinhos até a segunda geração, porém apresentou uma queda acentuada na terceira geração (Tabela 1).

Considerando-se os índices de infestação mínimo e máximo apurados nas seis amostragens realizadas nas duas localidades, 0,7 e 11,1 ninfas por metro linear, respectivamente, e as variações observadas entre eles, pode-se afirmar que o conjunto de dados obtidos representa os níveis de infestação da cigarrinha-das-raízes observados com maior freqüência nos canaviais do Estado de São Paulo.

Almeida (2002), analisando os dados de monitoramento da cigarrinha-dasraízes em doze usinas de açúcar situadas em diferentes regiões do Estado de São 
Paulo, verificou que aproximadamente $90 \%$ das áreas amostradas apresentaram índices de infestação inferiores a 10 ninfas/m linear.

Tabela 1. Número total e médio de ninfas da cigarrinha-das-raízes, Mahanarva fimbriolata em cana-de-açúcar, encontradas em três épocas de amostragem em Ourinhos e Guariba-SP, entre 2003 e 2004 ( N = 3.600 pontos de $1 \mathrm{~m}$ linear/época)

\begin{tabular}{ccccc}
\hline & & & \multicolumn{2}{c}{ Ninfas } \\
Local & Data & Época & Total & Média/m \\
\hline Ourinhos-SP & $29 / 10 / 03$ & 1 & 19.611 & 5,4 \\
& $21 / 01 / 04$ & 2 & 40.006 & 11,1 \\
& $30 / 03 / 04$ & 3 & 32.959 & 9,2 \\
Guariba-SP & $11 / 11 / 03$ & 1 & 5.398 & 1,5 \\
& $03 / 02 / 04$ & 2 & 39.608 & 11,0 \\
& $05 / 04 / 04$ & 3 & 2.417 & 0,7 \\
\hline
\end{tabular}

O índice de Morisita $\left(I_{\delta}\right)$ calculado para a população de ninfas da cigarrinhadas-raízes, $M$. fimbriolata, foi superior a 1 nas três épocas de amostragens, tanto em Ourinhos quanto em Guariba (Tabela 2), sendo os valores obtidos significativos ao nível de $5 \%$ de probabilidade.

Estes resultados indicam que as ninfas de $M$. fimbriolata distribuem-se de forma agregada ou contagiosa na cultura da cana-de-açúcar, e que este padrão de distribuição não se altera ao longo das gerações, nem é influenciado pelo nível de infestação ou variedade cultivada.

Resultados semelhantes foram obtidos na América Central por Evans (1972) para as cigarrinhas radicícolas: Aeneolamia varia saccharina (Distant) e Aeneolamia postica jugata (Walker), em cana-de-açúcar. 
Tabela 2. Índice de Morisita $\left(I_{\delta}\right)$ e valor de $F_{0}$ calculados com base na população de ninfas da cigarrinha-das-raízes, Mahanarva fimbriolata, em três épocas de amostragem em Ourinhos e Guariba-SP, entre 2003 e 2004

\begin{tabular}{cccccc}
\hline \multirow{2}{*}{ Local } & Data & Época & Ninfas $/ \mathrm{m}$. & Morisita $\left(I_{\delta}\right)$ & $F_{0}$ \\
\hline Ourinhos-SP & $29 / 10 / 03$ & 1 & 5,4 & $2,05^{*}$ & 6,71 \\
& $21 / 01 / 04$ & 2 & 11,1 & 1,82 * & 10,10 \\
& $30 / 03 / 04$ & 3 & 9,2 & $1,74 *$ & 7,74 \\
Guariba-SP & $11 / 11 / 03$ & 1 & 1,5 & $5,51^{*}$ & 7,76 \\
& $03 / 02 / 04$ & 2 & 11,0 & $1,48^{*}$ & 6,24 \\
& $05 / 04 / 04$ & 3 & 0,7 & $3,48 *$ & 2,66 \\
\hline
\end{tabular}

* Significativo ao nível de 5\% de probabilidade

$\mathrm{Na}$ literatura encontram-se diversos índices para medir a agregação ou dispersão de organismos, tais como: razão variância/média (Elliott, 1979), índice de Taylor (Taylor, 1961; 1965), índice de agregação de Lloyd (Lloyd, 1967), dentre outros. Porém nenhum deles é adequado a todos os casos já que, em maior ou menor grau, eles são afetados pelo número e tamanho das amostras e pela média amostral (Bianco, 1982). O índice proposto por Morisita e escolhido para a realização deste trabalho apresenta a vantagem de ser relativamente independente do tipo de distribuição, do número de amostras e da infestação média (Silveira Neto, 1976; 1990).

A distribuição espacial agregada da população de ninfas, observada nas amostragens realizadas em Ourinhos e Guariba, pode ser mais bem visualizada quando os dados são representados em gráficos tridimensionais, para a primeira (Figuras 5 e 6), segunda (Figuras 7 e 8 ) e terceira épocas(Figuras 9 e 10). 


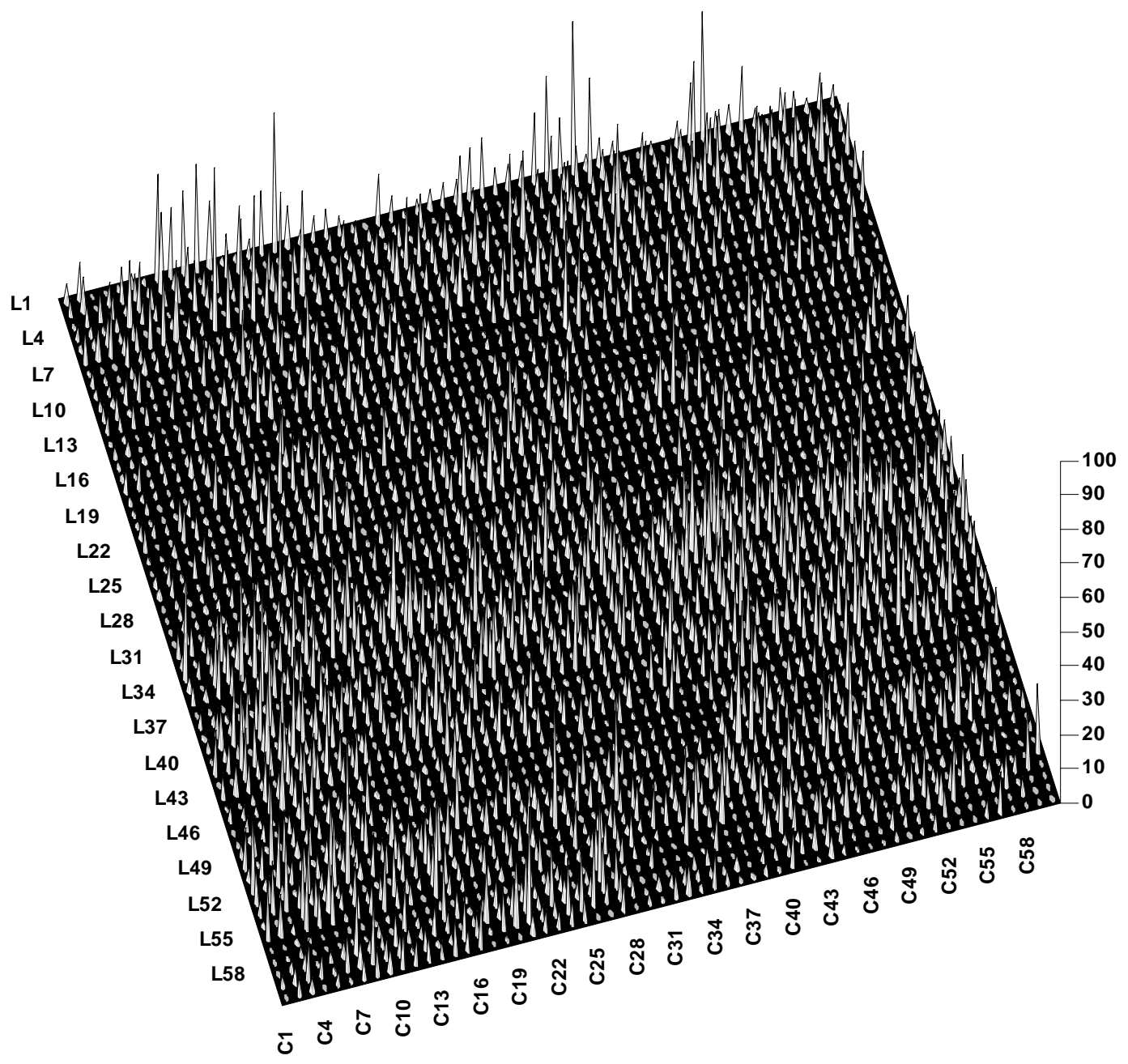

Figura 5 - Distribuição espacial de ninfas da cigarrinha da raiz, Mahanarva fimbriolata, em cana-de-açúcar. Fazenda Bela Vista, Ourinhos-SP, 29/10/2003 (primeira época) 


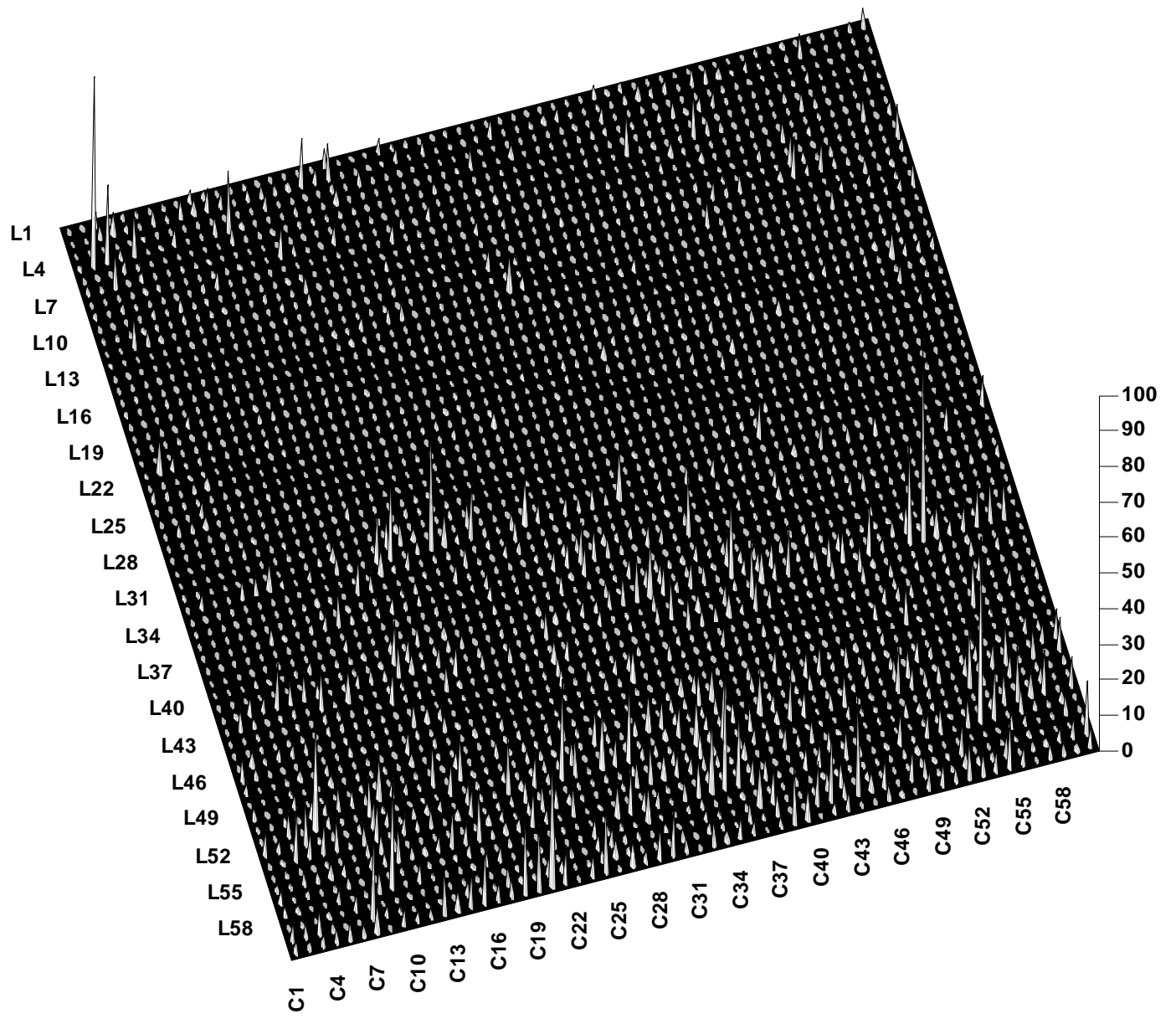

Figura 6 - Distribuição espacial de ninfas da cigarrinha da raiz, Mahanarva fimbriolata, em cana-de-açúcar. Fazenda Bibiana, Guariba-SP, 11/11/2003 (primeira época) 


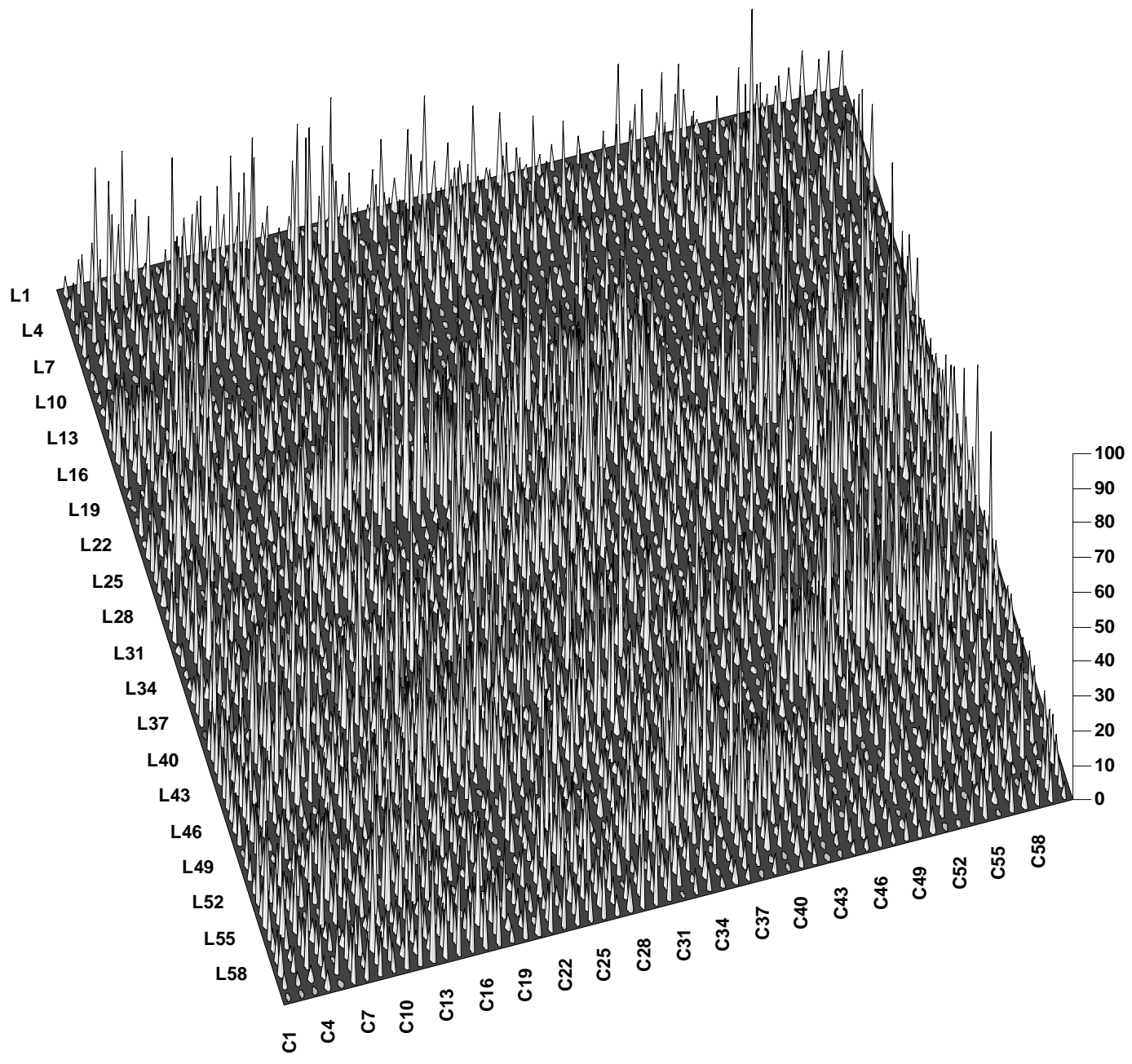

Figura 7 - Distribuição espacial de ninfas da cigarrinha da raiz, Mahanarva fimbriolata, em cana-de-açúcar. Fazenda Bela Vista, Ourinhos-SP, 21/01/2004 (segunda época) 


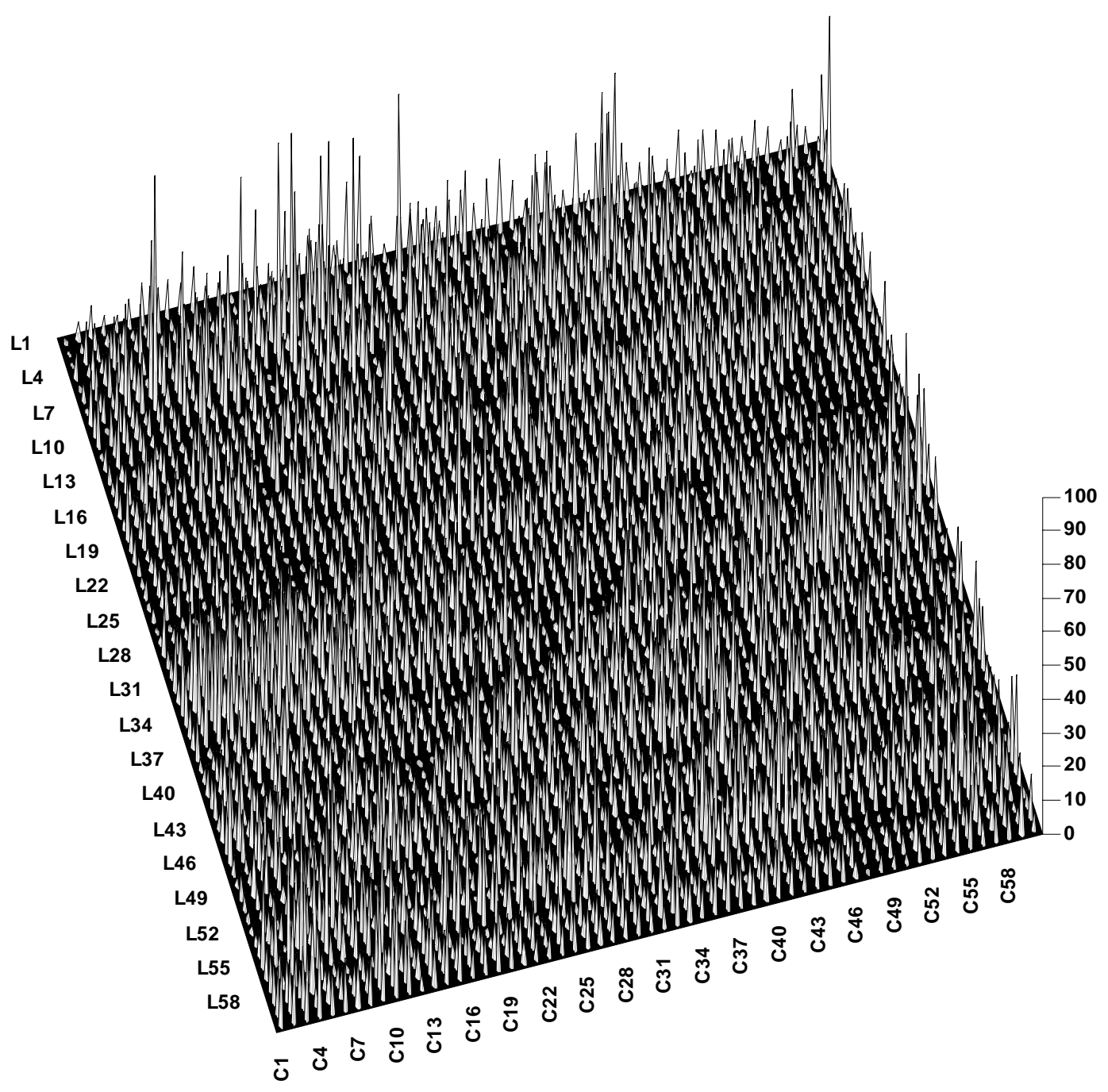

Figura 8 - Distribuição espacial de ninfas da cigarrinha da raiz, Mahanarva fimbriolata, em cana-de-açúcar. Fazenda Bibiana, Guariba-SP, 03/02/2004 (segunda época) 


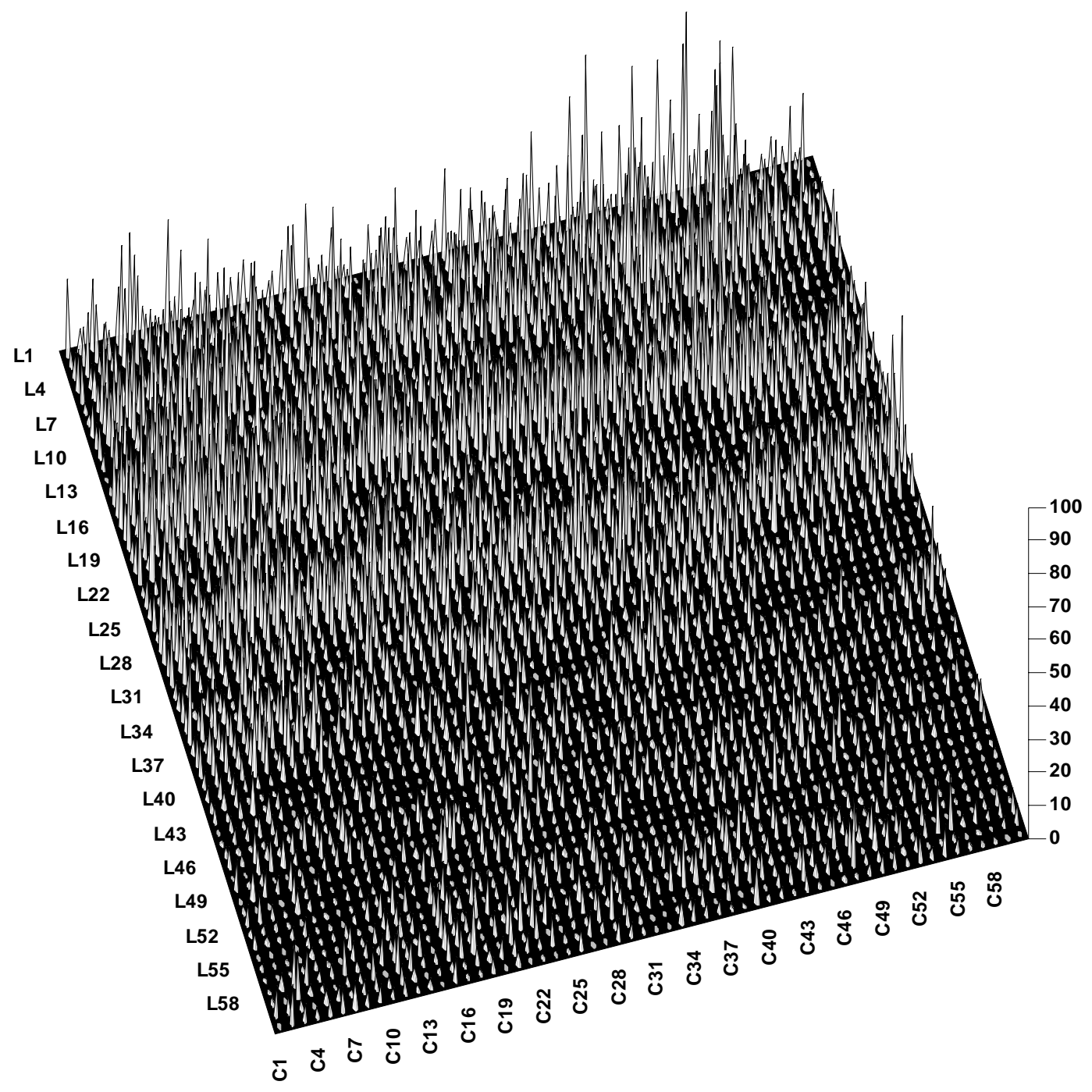

Figura 9 - Distribuição espacial de ninfas da cigarrinha da raiz, Mahanarva fimbriolata, em cana-de-açúcar. Fazenda Bela Vista, Ourinhos-SP, 30/03/2004 (terceira época) 


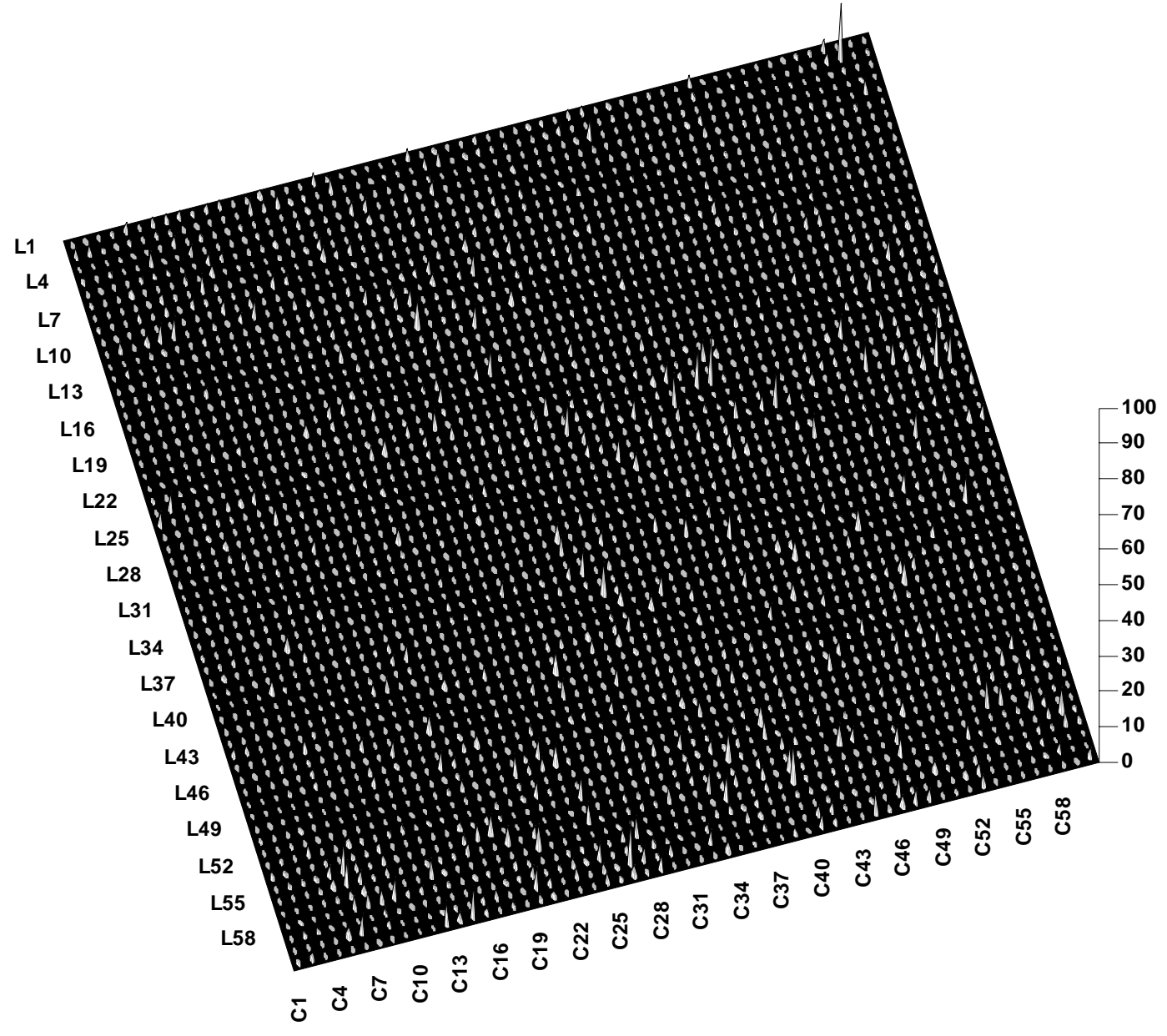

Figura 10 -Distribuição espacial de ninfas da cigarrinha da raiz, Mahanarva fimbriolata, em cana-de-açúcar. Fazenda Bibiana, Guariba-SP, 05/04/2004 (terceira época) 


\subsubsection{Modelo de distribuição espacial de adultos}

As contagens de adultos realizadas em Ourinhos e Guariba demonstram que as populações apresentaram uma tendência de crescimento contínuo ao longo das gerações, exceção feita à terceira época de amostragem em Guariba, pelos motivos já discutidos anteriormente (Tabela 3).

Como a época de amostragem dos experimentos foi definida priorizando-se o pico populacional de ninfas da cigarrinha-das-raízes, a população de adultos neste momento, provavelmente não correspondeu ao nível de infestação máximo no campo, já que existe uma defasagem de aproximadamente 30 dias entre o pico de ninfas e adultos, a cada geração (Almeida, 2001). Todavia, os índices médios de infestação apurados, entre 0,16 e 3,92 adultos/m linear, representam os níveis populacionais encontrados com maior freqüência no Estado de São Paulo (Arrigoni, E.D.B, comunicação pessoal).

Tabela 3. Número total e médio de adultos da cigarrinha-das-raízes, Mahanarva fimbriolata em cana-de-açúcar, encontradas três épocas de amostragem em Ourinhos e Guariba-SP, entre 2003 e 2004 ( $N=3.600$ pontos de $1 \mathrm{~m}$ linear/época)

\begin{tabular}{ccccc}
\hline & & & \multicolumn{2}{c}{ Adultos } \\
Local & Data & Época & Total & Média/m \\
\hline Ourinhos-SP & $29 / 10 / 03$ & 1 & 824 & 0,22 \\
& $21 / 01 / 04$ & 2 & 8.658 & 2,40 \\
& $30 / 03 / 04$ & 3 & 14.105 & 3,92 \\
Guariba-SP & $11 / 11 / 03$ & 1 & 557 & 0,16 \\
& $03 / 02 / 04$ & 2 & 5.393 & 1,49 \\
& $05 / 04 / 04$ & 3 & 1.213 & 0,33 \\
\hline
\end{tabular}


O índice de Morisita $\left(I_{\delta}\right)$ calculado para a população de adultos da cigarrinha-das-raízes, $M$. fimbriolata, foi maior que 1 nas três épocas de amostragem, tanto em Ourinhos como em Guariba, sendo os valores obtidos significativos ao nível de $5 \%$ de probabilidade (Tabela 4 ).

Estes dados revelam que, assim como as ninfas, os adultos da cigarrinhadas-raízes também se distribuem de forma agregada ou contagiosa na cultura da canade-açúcar, e que este padrão de distribuição não se altera ao longo das gerações, nem é influenciado pelo nível de infestação ou variedade cultivada.

Os resultados deste trabalho foram semelhantes aos obtidos por Evans (1972) para a espécie de cigarrinha $A$. postica jugata em cana-de-açúcar, mas diferentes dos obtidos pelo mesmo autor para a espécie A.varia saccharina, cujo padrão de distribuição espacial foi ao acaso.

Tabela 4. Índice de Morisita $\left(I_{\delta}\right)$ e valor de $F_{0}$ calculados com base na população de adultos da cigarrinha-das-raízes, Mahanarva fimbriolata, em três épocas de amostragem em Ourinhos e Guariba-SP, entre 2003 e 2004

\begin{tabular}{cccccc}
\hline \multirow{2}{*}{ Local } & Data & Época & Adultos $/ \mathrm{m}$ & Morisita $\left(I_{\delta}\right)$ & $F_{0}$ \\
\hline Ourinhos-SP & $29 / 10 / 03$ & 1 & 0,22 & $3,85^{*}$ & 1,65 \\
& $21 / 01 / 04$ & 2 & 2,40 & $1,85^{*}$ & 3,05 \\
& $30 / 03 / 04$ & 3 & 3,92 & $1,46 *$ & 2,82 \\
Guariba-SP & $11 / 11 / 03$ & 1 & 0,16 & $5,05^{*}$ & 1,62 \\
& $03 / 02 / 04$ & 2 & 1,49 & $1,88^{*}$ & 2,32 \\
& $05 / 04 / 04$ & 3 & 0,33 & 2,36 * & 1,46 \\
\hline
\end{tabular}

* Significativo ao nível de 5\% de probabilidade 


\subsubsection{Definição do tamanho da amostra e esquema de caminhamento}

Existem diversos modelos que descrevem matematicamente o padrão de distribuição agregada dos organismos. Dentre estes, o mais utilizado em entomologia é a binomial negativa (Norris et al., 2001), proposto por Bliss \& Fisher (1953) para os casos onde a variância é significativamente maior que a média, como observado para M. fimbriolata em cana-de-açúcar.

Além disso, o conhecimento do ciclo biológico do inseto é fundamental para se determinar a fase mais adequada a ser amostrada. Em geral, esta opção é feita priorizando-se a fase de vida que causa maior prejuízo à cultura ou a mais estável no ambiente. No caso da cigarrinha-das-raízes, por apresentar pouca mobilidade, as ninfas são as mais indicadas para o acompanhamento da sua dinâmica populacional no campo, o que já vem sendo feito por diversos autores (Guagliumi, 1972/1973; Mendonça, 1996; Almeida, 2001; Novaretti et al., 2001; Macedo et al., 2002; DinardoMiranda, 2003).

Portanto, considerando-se que a distribuição espacial das ninfas de $M$. fimbriolata se ajustou ao modelo de distribuição binomial negativa, em todas as amostragens, foram calculados os índices de dispersão $k$ inicial e ideal, para determinar o tamanho da amostra necessário para estimar a população desta fase do ciclo biológico da cigarrinha-das-raízes (Tabela 5). 
Tabela 5. Valores de $\mathrm{k}$ inicial e ideal e índice médio de infestação de ninfas da cigarrinha-das-raízes, Mahanarva fimbriolata, em três épocas de amostragem em Ourinhos e Guariba-SP, entre 2003 e 2004

\begin{tabular}{ccccc}
\hline \multirow{2}{*}{ Local } & Data & Ninfas/m & k inicial & k ideal \\
\hline Ourinhos-SP & $29 / 10 / 03$ & 5,4 & 0,95 & 0,95 \\
& $21 / 01 / 04$ & 11,1 & 1,22 & 1,35 \\
& $30 / 03 / 04$ & 9,2 & 1,36 & 1,33 \\
Guariba-SP & $11 / 11 / 03$ & 1,5 & 0,22 & 0,34 \\
& $03 / 02 / 04$ & 11,0 & 2,10 & 2,61 \\
& $05 / 04 / 04$ & 0,7 & 0,40 & 0,45 \\
\hline
\end{tabular}

Os valores de tamanho de tamanho da amostra para representar a população de ninfas da cigarrinha-das-raízes, $M$ fimbriolata, calculados a partir do índice de dispersão ( $\mathrm{k}$ ideal), indicam que houve uma grande variação na quantidade de amostras determinadas para cada local e época de amostragem, nos níveis de precisão considerados. Valores extremos foram observados em Guariba, sendo o maior número de amostras determinado para a primeira e terceira épocas de avaliação e o menor para a segunda época. Tamanhos de amostra intermediários foram determinados em Ourinhos, sendo os valores obtidos para a primeira época mais elevados que os obtidos para a segunda e terceira épocas, que foram muito próximos (Tabela 6).

Com base nestas observações, pode-se afirmar que o tamanho da amostra foi influenciado pelo índice médio de infestação, sendo a relação entre estes parâmetros inversamente proporcional, ou seja, quanto menor a densidade populacional do inseto na área, maior o número de amostras necessárias para estimar a população.

Resultados semelhantes foram obtidos por Nilakhe (1982) para populações de ninfas das cigarrinhas Zulia entreriana (Berg., 1879), Deois flavopicta (Stål., 1854) e M. fimbriolata, em pastagem. 
Contudo, o tamanho da amostra não é influenciado exclusivamente pelo índice de infestação. Comparando-se as amostragens realizadas na segunda época dos dois experimentos verifica-se que, embora os índices de infestação apurados tenham sido muito próximos, o tamanho de amostra determinada para Guariba foi menor que para Ourinhos (Tabela 6). Esta variação pode ser atribuída às diferenças no padrão de distribuição espacial da cigarrinha-das-raízes nas áreas experimentais, demonstradas matematicamente pelos índices de dispersão obtidos para cada amostragem (Tabela 5) Quanto maior a agregação da população, maior o número de amostras são necessárias para um mesmo nível de precisão.

Tabela 6. Número de amostras/ha necessárias para estimar a população de ninfas da cigarrinha-das-raízes, Mahanarva fimbriolata, em função da infestação média de ninfas/m e dos níveis de precisão desejados

\begin{tabular}{lcccccccccc}
\hline & \multicolumn{10}{c}{ Nível de precisão (\%) } \\
Local & Data & Ninfas/m & 15 & 20 & 25 & 30 & 35 & 40 & 45 & 50 \\
\hline Ourinhos-SP & $29 / 10 / 03$ & 5,4 & 192 & 107 & 69 & 48 & 35 & 27 & 21 & 17 \\
& $21 / 01 / 04$ & 11,1 & 131 & 74 & 47 & 33 & 24 & 18 & 15 & 12 \\
& $30 / 03 / 04$ & 9,2 & 135 & 75 & 48 & 34 & 25 & 19 & 15 & 12 \\
Guariba-SP & $11 / 11 / 03$ & 1,5 & 563 & 316 & 203 & 141 & 104 & 79 & 63 & 51 \\
& $03 / 02 / 04$ & 11,0 & 75 & 42 & 26 & 18 & 14 & 10 & 8 & 6 \\
& $05 / 04 / 04$ & 0,7 & 593 & 334 & 214 & 148 & 109 & 84 & 65 & 54 \\
\hline
\end{tabular}

Correlacionando-se o tamanho da amostra para representar a população de ninfas da cigarrinha-das-raízes e a precisão da amostragem verifica-se que o número de amostras aumenta progressivamente à medida que aumenta o nível de precisão (= valores menores) (Figura 11). 


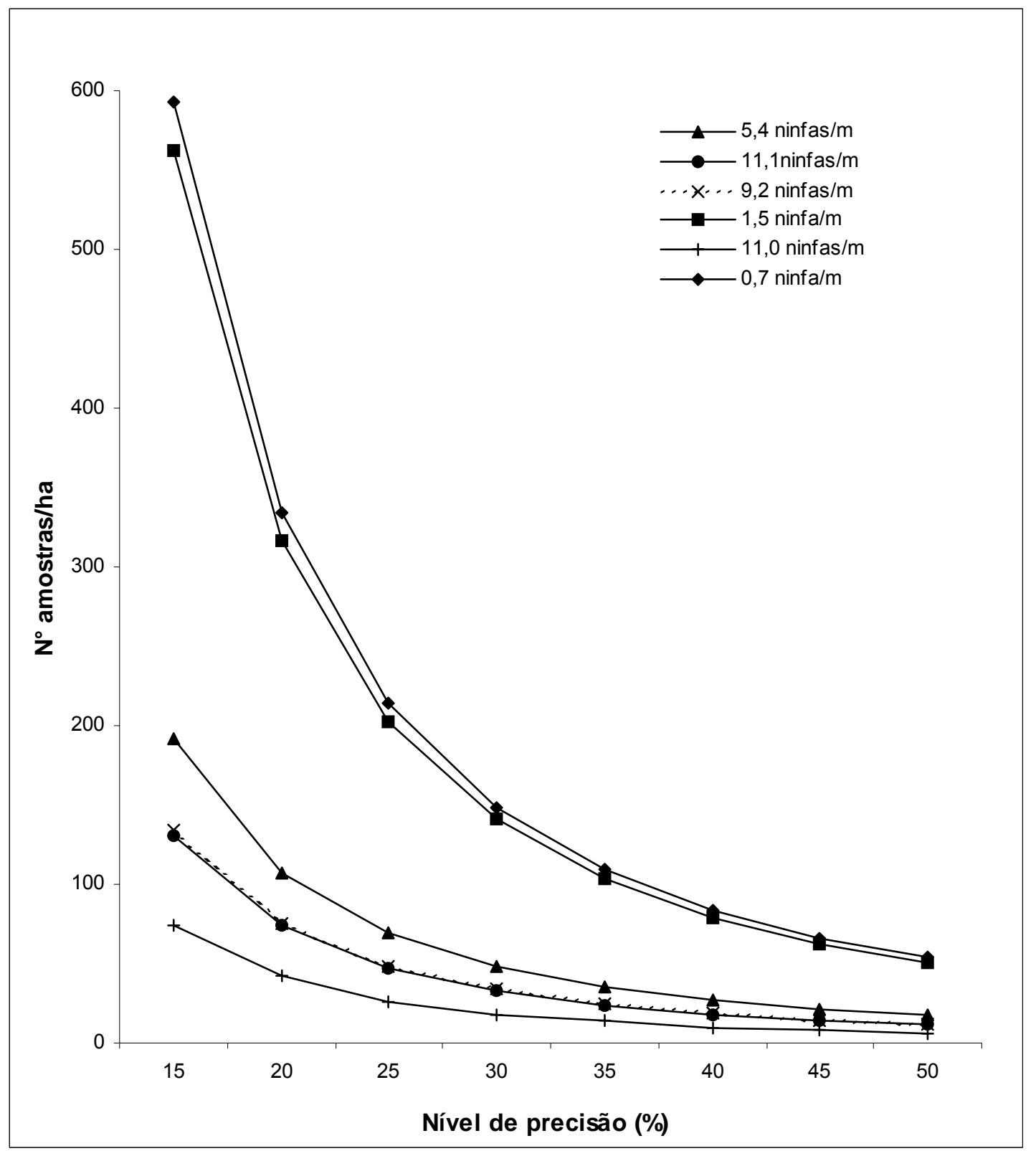

Figura 11 -Número de amostras necessárias para estimar a população de ninfas da cigarrinha-das-raízes, Mahanarva fimbriolata, em cana-de-açúcar, em função dos níveis de infestação e precisão admitido 
Quando o objetivo da amostragem é o manejo integrado de pragas recomenda-se que o nível de precisão não ultrapasse o valor de 25\% (Southwood, 1978). Entretanto, a questão econômica é fundamental para que o plano de amostragem proposto tenha aceitação pelos produtores.

Sendo assim, para a seleção do número de amostras avaliadas nas simulações e para a realização das simulações propriamente ditas, adotaram-se algumas premissas básicas. Optou-se por trabalhar com níveis de precisão entre 25 a $50 \%$ para representar a população de ninfas da cigarrinha-das-raízes, em razão do elevado número de amostras necessárias para níveis de precisão inferiores a $25 \%$. Além disso, pelo mesmo motivo, desprezaram-se as amostragens realizadas na primeira e terceira épocas no experimento de Guariba, que apresentaram os menores índices de infestação, ou seja, 1,5 e 0,7 ninfa por metro linear, respectivamente (Tabela 6).

Os valores de tamanho da amostra avaliados nas simulações com os diferentes esquemas de caminhamento foram: 48, 36, 24, 18 e 12 amostras/ha. Estes valores foram definidos com base na média das quatro amostragens que apresentaram os maiores índices de infestação (níveis de precisão de 25 a 50\%).

Os coeficientes hora-homem, estimado para cada combinação de tamanho de amostra e esquema de caminhamento, foram mais influenciados pelo número de amostras do que pelo esquema de caminhamento. Entretanto, à medida que o número de amostras diminuiu o caminhamento passou a ter maior participação neste índice (Tabela 7). 
Tabela 7. Coeficientes hora-homem para a execução de diferentes planos de amostragem para avaliação da população de ninfas da cigarrinha-dasraízes, Mahanarva fimbriolata, em cana-de-açúcar

\begin{tabular}{cccccc}
\hline $\begin{array}{c}\text { Esquema de } \\
\text { Caminhamento * }\end{array}$ & 48 & 36 & 24 & 18 & 12 \\
\hline A & 1,87 & 1,47 & 1,07 & 0,87 & 0,67 \\
B & 1,79 & 1,39 & 0,99 & 0,79 & 0,59 \\
C & 1,80 & 1,40 & 1,00 & 0,80 & 0,60 \\
D & 1,71 & 1,31 & 0,91 & 0,71 & 0,51 \\
E & 1,79 & 1,39 & 0,99 & 0,79 & 0,59 \\
F & 1,72 & 1,32 & 0,92 & 0,72 & 0,52 \\
\hline
\end{tabular}

* Vide figura 3 do item 3.2.3 para detalhamento do esquema de caminhamento

Os valores de Variação Relativa (VR), obtidos para cada combinação de tamanho de amostra e caminhamento (Tabela 8), demonstram que ocorreu um aumento deste índice à medida que o tamanho da amostra diminuiu, o que indica uma redução na precisão da amostragem. Em relação à Precisão Relativa (PR), como o custo da amostragem é levado em consideração, ocorreu o inverso, melhores resultados (valores maiores) foram observados à medida que o tamanho da amostra diminuiu (Tabela 9).

Com base na classificação dos valores médios de VR e PR, obtidos para as simulações realizadas com os seis esquemas propostos, para cada tamanho de amostra, em relação ao intervalo de confiança da média (Tabelas 8 e 9), verificou-se que a melhor opção de caminhamento foi o esquema "E", que apresentou valores de VR inferiores em $80 \%$ das simulações e valores de PR superiores em $60 \%$ dos casos.

Analisando-se a classificação dos valores médios de VR e PR, obtidos para as simulações realizadas com os diferentes tamanhos de amostra, para cada esquema de caminhamento, em relação ao intervalo de confiança da média (Tabelas 8 e 9), observou-se que VR para 48 amostras/ha foi inferior em $83 \%$ dos esquemas de 
caminhamento propostos. Em contrapartida a PR para este tamanho de amostra foi inferior em $67 \%$ dos casos, em função da elevada demanda de mão-de-obra para sua execução. Situação oposta foi observada para 12 amostras/ha, onde a PR e VR foram superiores em $83 \%$ e $100 \%$ dos esquemas de caminhamento, respectivamente.

Sendo assim, a opção mais adequada foi 18 amostras/ha, que apresentou valores de VR dentro do intervalo de confiança em $83 \%$ dos esquemas de caminhamento e valores de PR superiores ou dentro do intervalo em $100 \%$ dos casos. Vale ressaltar que no esquema de caminhamento selecionado (E), o valor de PR obtido para esse número de amostras foi superior.

Tabela 8. Valores de Variação Relativa (VR) calculados para simulações de amostragem da cigarrinha-das-raízes, Mahanarva fimbriolata, em cana-deaçúcar, comparando-se diferentes esquemas de caminhamento para cada tamanho de amostra

\begin{tabular}{|c|c|c|c|c|c|c|c|}
\hline \multirow{3}{*}{$\begin{array}{l}\text { Esquemas de } \\
\text { Caminhamento } \\
\text { A }\end{array}$} & \multicolumn{7}{|c|}{ Número de amostras/ha } \\
\hline & 48 & 36 & 24 & \multicolumn{2}{|l|}{18} & \multicolumn{2}{|c|}{12} \\
\hline & 6,1 d I & 6,9 d $D$ & 8,5 d $D$ & 8,6 i & $\mathrm{D}$ & $10,7 i$ & $S$ \\
\hline $\mathrm{B}$ & $6,1 \mathrm{~d} \quad \mathrm{I}$ & 7,7 d $D$ & 10,3 s $D$ & $11,2 d$ & $\mathrm{D}$ & 15,0 & s $S$ \\
\hline $\mathrm{C}$ & 6,3 s I & 8,0 s $\quad D$ & 9,8 s $\quad D$ & $11,7 \mathrm{~s}$ & $\mathrm{D}$ & 11,8 & d $S$ \\
\hline $\mathrm{D}$ & 5,3 i l & 7,0 d $D$ & 8,9 d $D$ & $11,6 \mathrm{~d}$ & $\mathrm{D}$ & 12,7 & d $S$ \\
\hline$E$ & 5,2 i $\quad D$ & 5,1 i D & 8,2 i $D$ & $8,4 \quad i$ & $\mathrm{D}$ & 13,0 & d $S$ \\
\hline $\mathrm{F}$ & 5,9 d $\quad$ l & 6,9 d $D$ & 8,4 d $D$ & $10,7 d$ & $S$ & 11,0 & i $S$ \\
\hline \multicolumn{8}{|c|}{ Intervalo de confiança (I.C.) calculado para médias das amostragens simuladas: } \\
\hline \multicolumn{8}{|c|}{$\begin{array}{l}\text { Para letras minúsculas na coluna (esquema de caminhamento) e minúsculas na linha (número } \\
\text { de amostras): }\end{array}$} \\
\hline \multicolumn{8}{|c|}{ S, s : valores acima do I.C. } \\
\hline \multicolumn{8}{|c|}{ D, $d$ : valores pertencentes ao I.C. } \\
\hline I, i : valores abaix & do I.C. & & & & & & \\
\hline
\end{tabular}


Tabela 9. Valores de Precisão Relativa (PR) calculados para simulações de amostragem da cigarrinha-das-raízes, Mahanarva fimbriolata, em cana-deaçúcar, comparando-se diferentes esquemas de caminhamento para cada tamanho de amostra

\begin{tabular}{|c|c|c|c|c|c|}
\hline \multirow{2}{*}{$\begin{array}{l}\text { Esquemas de } \\
\text { Caminhamento }\end{array}$} & \multicolumn{5}{|c|}{ Número de amostras/ha } \\
\hline & 48 & 36 & 24 & 18 & 12 \\
\hline$A$ & 8,8 i I & $9,9 \mathrm{~d} D$ & $11,0 \mathrm{~d} D$ & $13,4 d \mathrm{D}$ & $13,9 \mathrm{~d} S$ \\
\hline $\mathrm{B}$ & 9,2 d $\quad$ & $9,4 d \quad D$ & $9,8 \mathrm{i} \quad \mathrm{D}$ & $11,3 d S$ & 11,3 i S \\
\hline $\mathrm{C}$ & 8,9 i D & $8,9 \mathrm{i} \quad \mathrm{D}$ & 10,2 i D & $10,7 \mathrm{i} \quad \mathrm{D}$ & $14,1 \mathrm{~d} S$ \\
\hline $\mathrm{D}$ & 10,9 s D & $11,0 \mathrm{~d} D$ & $12,3 d \mathrm{D}$ & $12,1 \mathrm{~d} D$ & $15,5 \mathrm{~d} S$ \\
\hline$E$ & $10,8 \mathrm{~s} \quad \mathrm{I}$ & $14,1 \mathrm{~s} \quad \mathrm{D}$ & $12,4 \mathrm{~d} D$ & $15,2 \mathrm{~s} S$ & $13,0 \mathrm{~d}$ \\
\hline $\mathrm{F}$ & 9,9 s I & $11,0 \mathrm{~d} D$ & $12,9 \mathrm{~s} D$ & $13,0 \mathrm{~d} D$ & $17,5 \mathrm{~s} \mathrm{~s}$ \\
\hline \multicolumn{6}{|c|}{ Intervalo de confiança (I.C.) calculado para médias das amostragens simuladas: } \\
\hline \multicolumn{6}{|c|}{$\begin{array}{l}\text { Para letras minúsculas na coluna (esquema de caminhamento) e minúsculas na linha (núm } \\
\text { de amostras): }\end{array}$} \\
\hline \multicolumn{6}{|c|}{ S, s : valores acima do I.C. } \\
\hline \multicolumn{6}{|c|}{$\mathrm{D}, \mathrm{d}$ : valores pertencentes ao I.C. } \\
\hline $\mathrm{I}, \mathrm{i}$ : valores aba & o do l.C. & & & & \\
\hline
\end{tabular}

Com base nos resultados das simulações realizadas, verificou-se que o plano de amostragem mais adequado para a avaliação das populações da cigarrinhadas-raízes, na cultura da cana-de-açúcar, foi a tomada de 18 amostras de 1 metro linear por hectare, distribuídas conforme esquema "E" de caminhamento (Figura 12).

Para que a amostra seja representativa é fundamental que a área avaliada seja padronizada, $1 \mathrm{~m}$ na linha e $0,5 \mathrm{~m}$ de cada lado da linha de cana, e que não existam falhas de brotação do canavial e alterações no padrão de distribuição da palha no local determinado para o levantamento.

Apesar da tomada de decisão e da avaliação da eficiência das medidas de controle levar em consideração a população de ninfas, a contagem de adultos no solo e nas folhas é importante, principalmente quando o programa de manejo integrado é 
baseado no controle microbiano, pois esta é a fase do inseto onde se verifica maior porcentagem de infecção por fungos entomopatogênicos. 


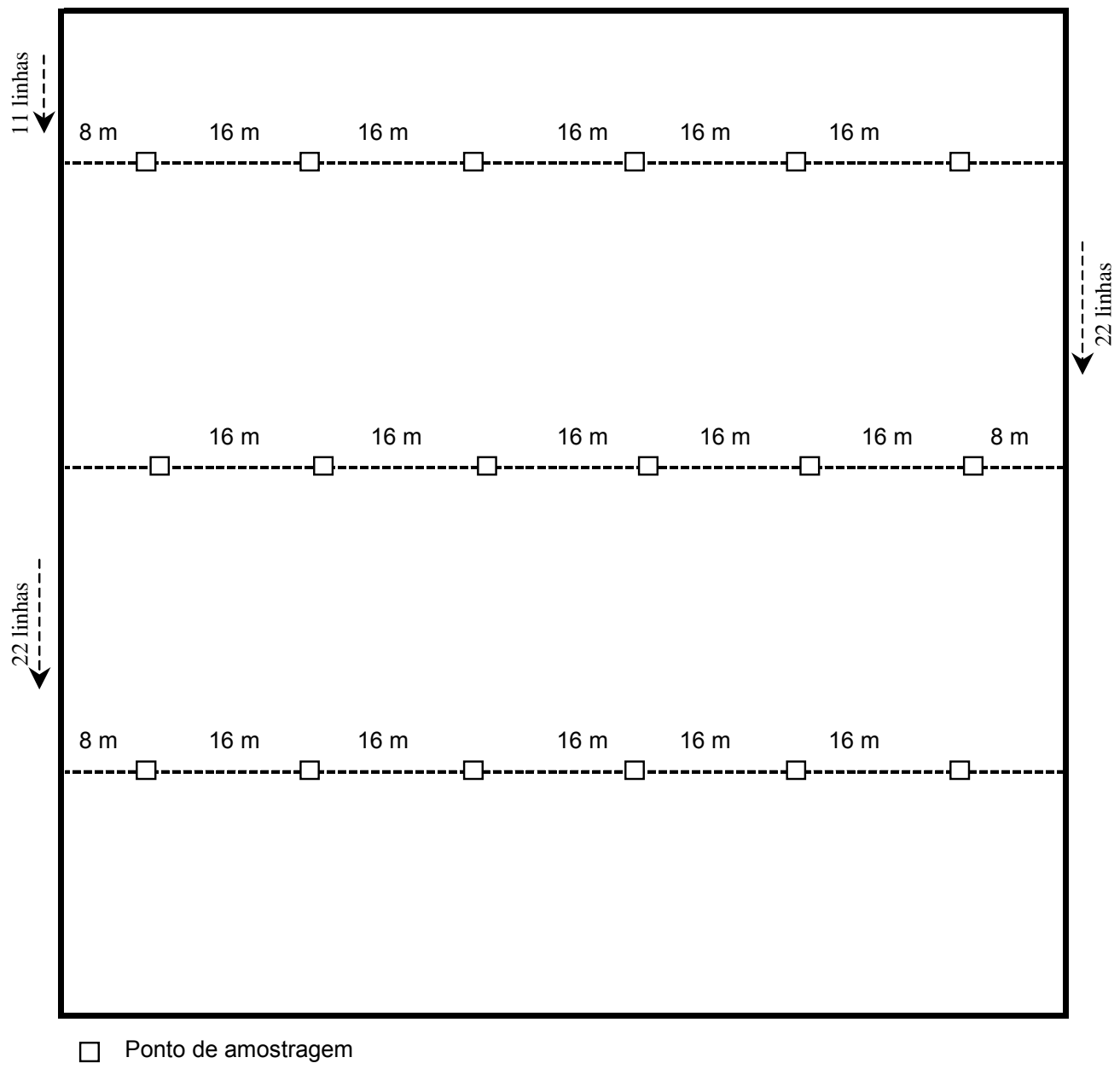

Figura 12 -Esquema de amostragem proposto para o monitoramento da cigarrinhadas-raízes em programas de manejo integrado, na cultura da cana-deaçúcar 


\subsection{Avaliação do sistema de amostragem comercial}

\subsubsection{Dinâmica populacional}

As curvas de flutuação populacional da cigarrinha-das-raízes, M. fimbriolata, nas Fazendas Bela Vista e Água Suja, construídas com os dados obtidos na amostragem experimental, evidenciam a ocorrência de três gerações da praga se desenvolvendo entre os meses de outubro de 2003 e maio de 2004 (Figuras 13 e 14). A primeira geração ocorreu de outubro até dezembro, a segunda em janeiro e fevereiro e a terceira geração de março a meados de maio. A partir daí as populações de adultos e ninfas decresceram atingindo índices populacionais muito baixos no final do outono e durante o inverno, sem, entretanto desaparecer dos canaviais, mesmo nos meses com baixa pluviosidade.

$\mathrm{Na}$ Fazenda Bela Vista a população de ninfas apresentou crescimento progressivo ao longo das gerações, atingindo o pico em março de 2004 (10,2 ninfas $(m)$, na terceira geração. Na Fazenda Água Suja, o pico foi alcançado no mês de janeiro (16 ninfas $/ \mathrm{m}$ ), na segunda geração da praga, apresentando uma curva populacional mais típica para o Estado de São Paulo (Almeida, 2001).

A população de adultos teve crescimento progressivo ao longo das gerações e atingiu o pico em abril, com 4,7 e 4,6 adultos/m nas Fazendas Bela Vista e Água Suja, respectivamente.

Comparando-se as curvas populacionais da cigarrinha-das-raízes obtidas nas duas propriedades verifica-se que houve uma defasagem de aproximadamente 30 dias entre os picos de ninfas e adultos, a cada geração. Observação semelhante foi mencionada por Almeida (2001). 


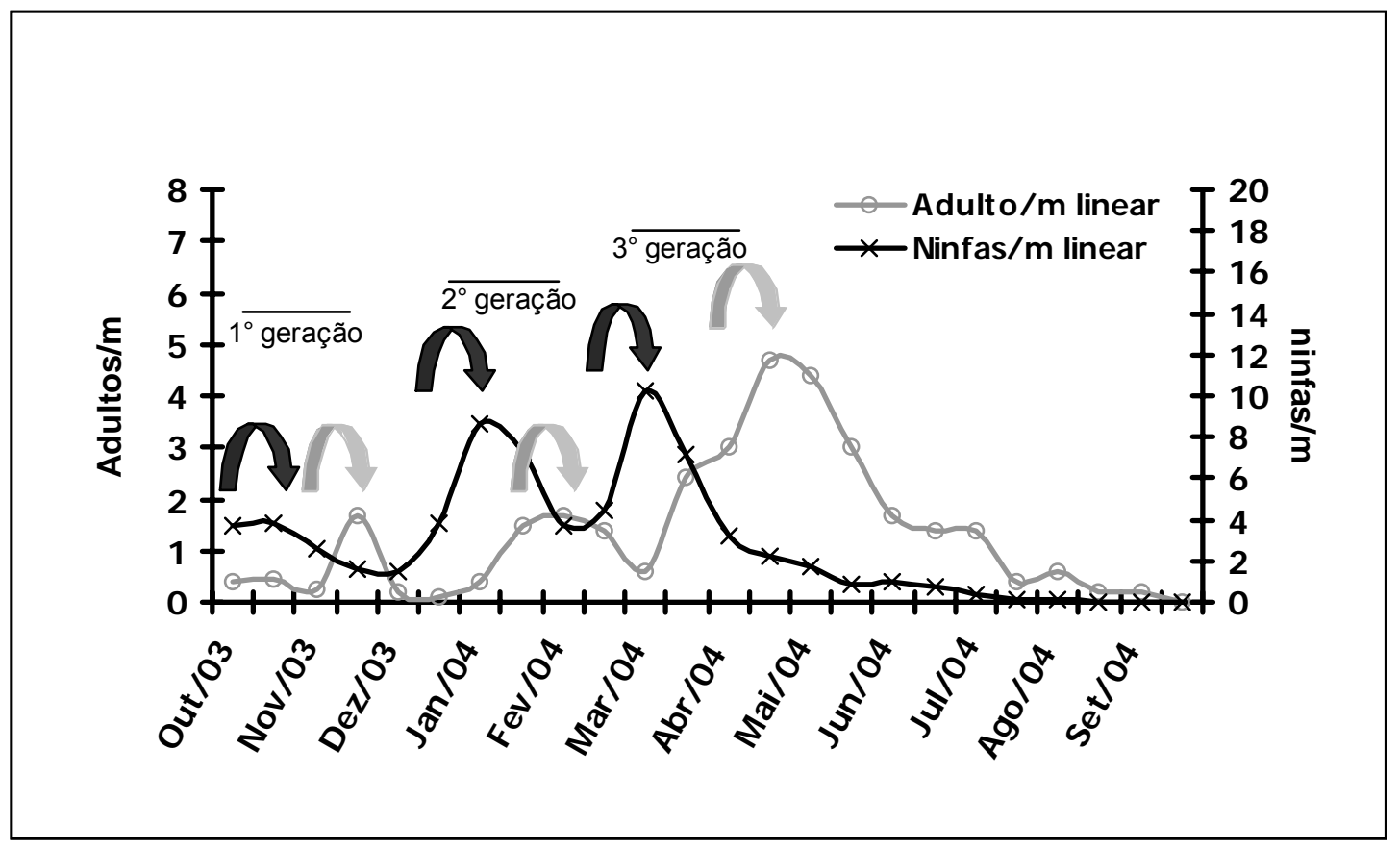

Figura 13 -Flutuação populacional da cigarrinha-das-raízes da cana-de-açúcar, Mahanarva fimbriolata, obtida na Fazenda Bela Vista, Ourinhos-SP, entre os meses de outubro de 2003 e setembro de 2004 


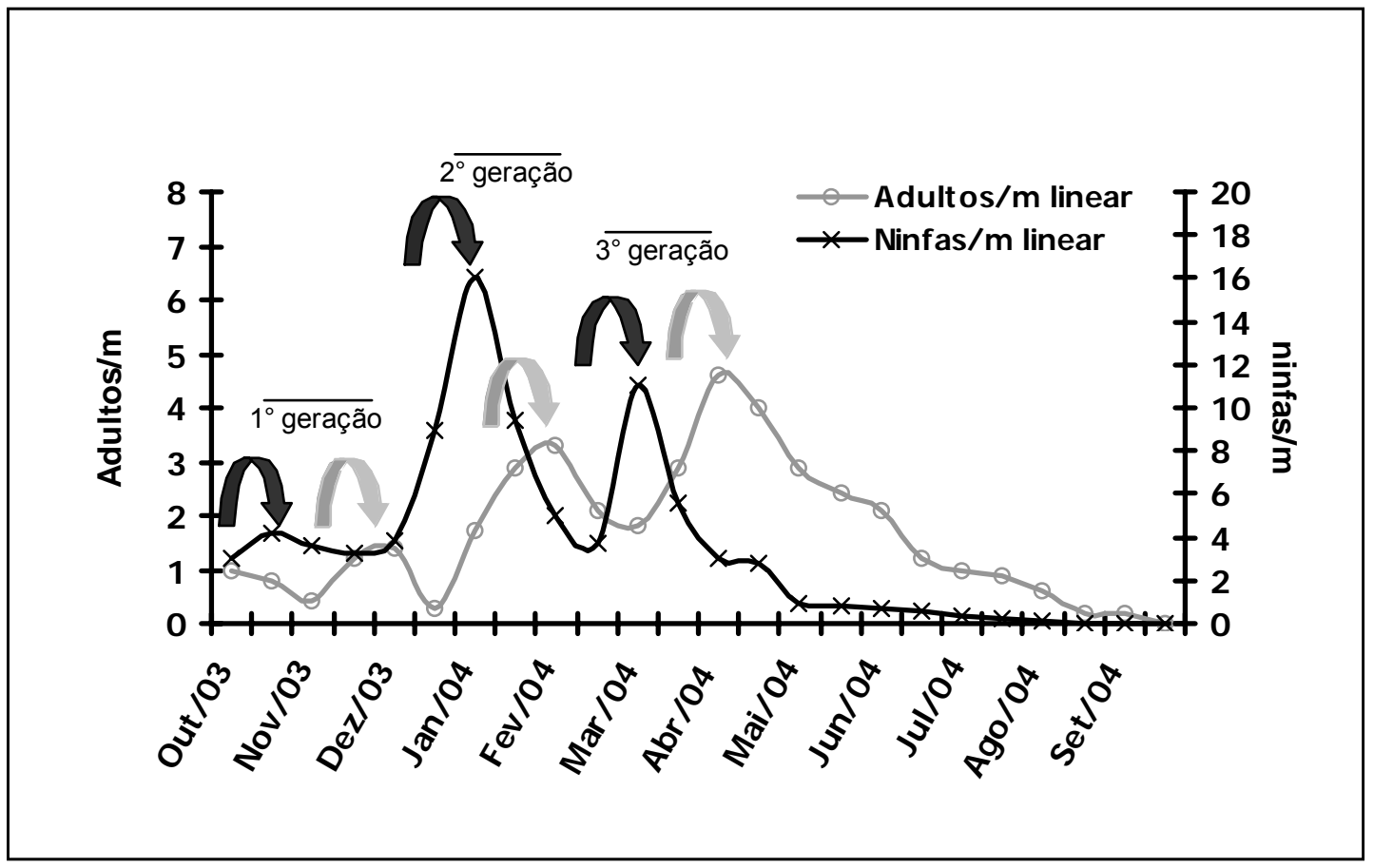

Figura 14 -Flutuação populacional da cigarrinha-das-raízes da cana-de-açúcar, Mahanarva fimbriolata, obtida na Fazenda Água Suja, Ourinhos-SP, entre os meses de outubro de 2003 e setembro de 2004 


\subsubsection{Comparação da amostragem comercial e amostragem experimental}

Comparando-se a flutuação populacional de ninfas da cigarrinha-das-raízes, por meio de uma análise de regressão linear e pelo coeficiente de determinação, nas Fazendas Bela Vista e Água Suja, observou-se que os índices de infestação na AC foram sempre inferiores aos da $A E$, independente da época da amostragem (Figura 15). Por outro lado, verificou-se uma alta correlação entre os dados das duas amostragens, AC e AE, para as Fazendas Bela Vista e Água Suja, com coeficientes de determinação $\left(R^{2}\right)$ iguais a 0,83 e 0,81 , respectivamente.

Para a flutuação populacional de adultos da cigarrinha-das-raízes, nas Fazendas Bela Vista e Água Suja, os índices de infestação na AC também foram sempre inferiores aos da AE (Figura 16). Entretanto, a correlação entre as duas amostragens foi significativamente mais baixa que a obtida para a população de ninfas, com coeficientes de determinação $\left(R^{2}\right)$ de 0,50 e 0,68 para as Fazendas Bela Vista e Água Suja, respectivamente.

Os resultados obtidos demonstram que a $A C$ apresentou uma boa precisão na estimativa das populações de ninfas da cigarrinha, porém foi pouco precisa na estimativa da população de adultos. Ao mesmo tempo, nota-se que a acurácia da AC, foi baixa tanto para ninfas quanto para os adultos, subestimando as populações da cigarrinha-das-raízes, M. fimbriolata.

Apesar da AC apresentar uma boa precisão na estimativa da população de ninfas da cigarrinha-das raízes, por ser um método empírico, recomenda-se a adoção do plano de amostragem proposto no item 4.1.3 que foi desenvolvido a partir do modelo de distribuição espacial do inseto e selecionado por critérios estatísticos e econômicos, dentre 30 combinações de tamanho de amostra e esquemas de caminhamento. 

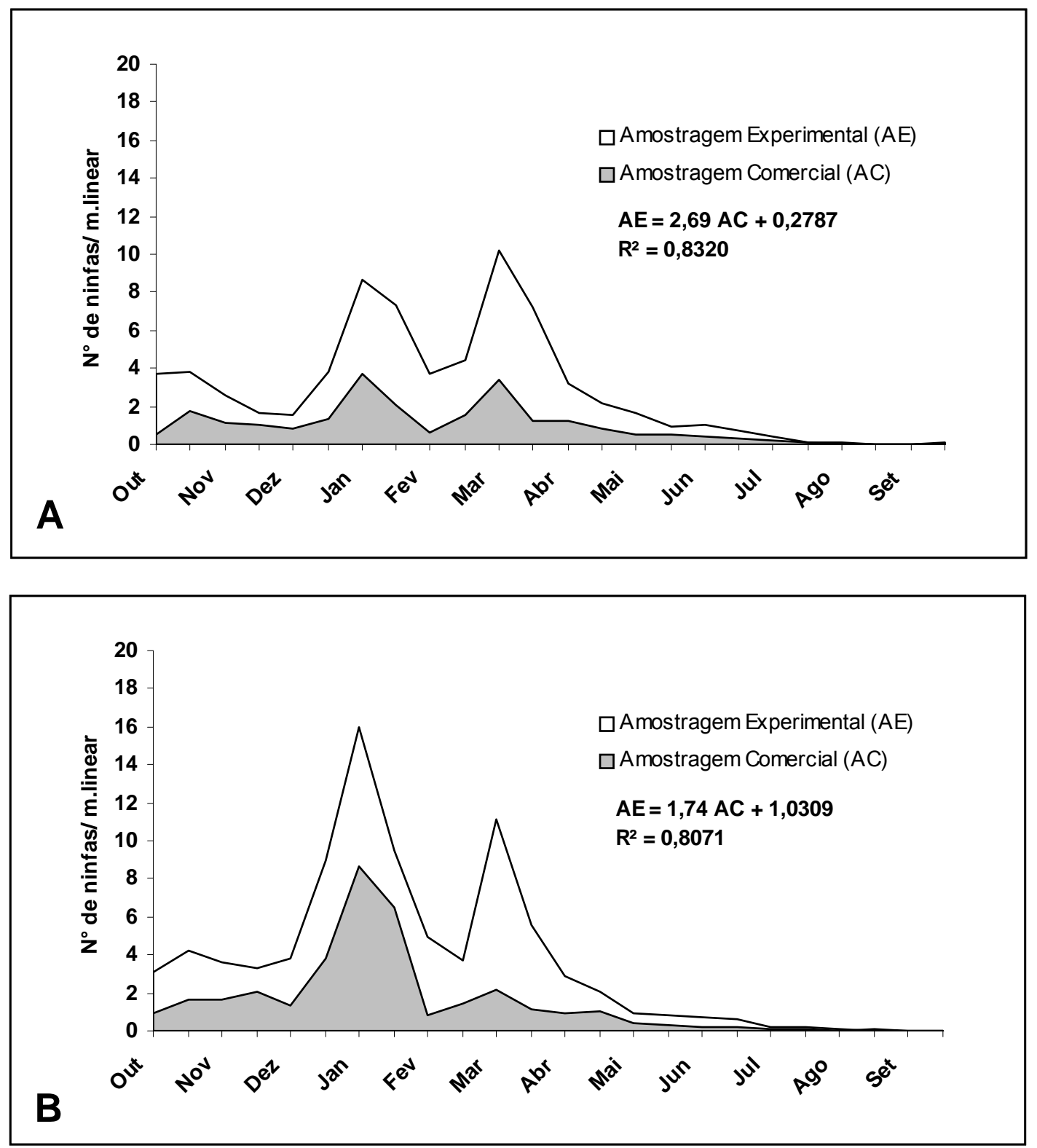

Figura 15 -Equação de regressão linear, coeficiente de determinação e flutuação populacional de ninfas da cigarrinha-das-raízes da cana-de-açúcar, Mahanarva fimbriolata, para comparação dos dados da Amostragem Comercial (AC) e Amostragem Experimental ( $A E)$, realizadas nas Fazendas Bela Vista (A) e Água Suja (B), em Ourinhos-SP, entre os meses de outubro de 2003 e setembro de 2004 

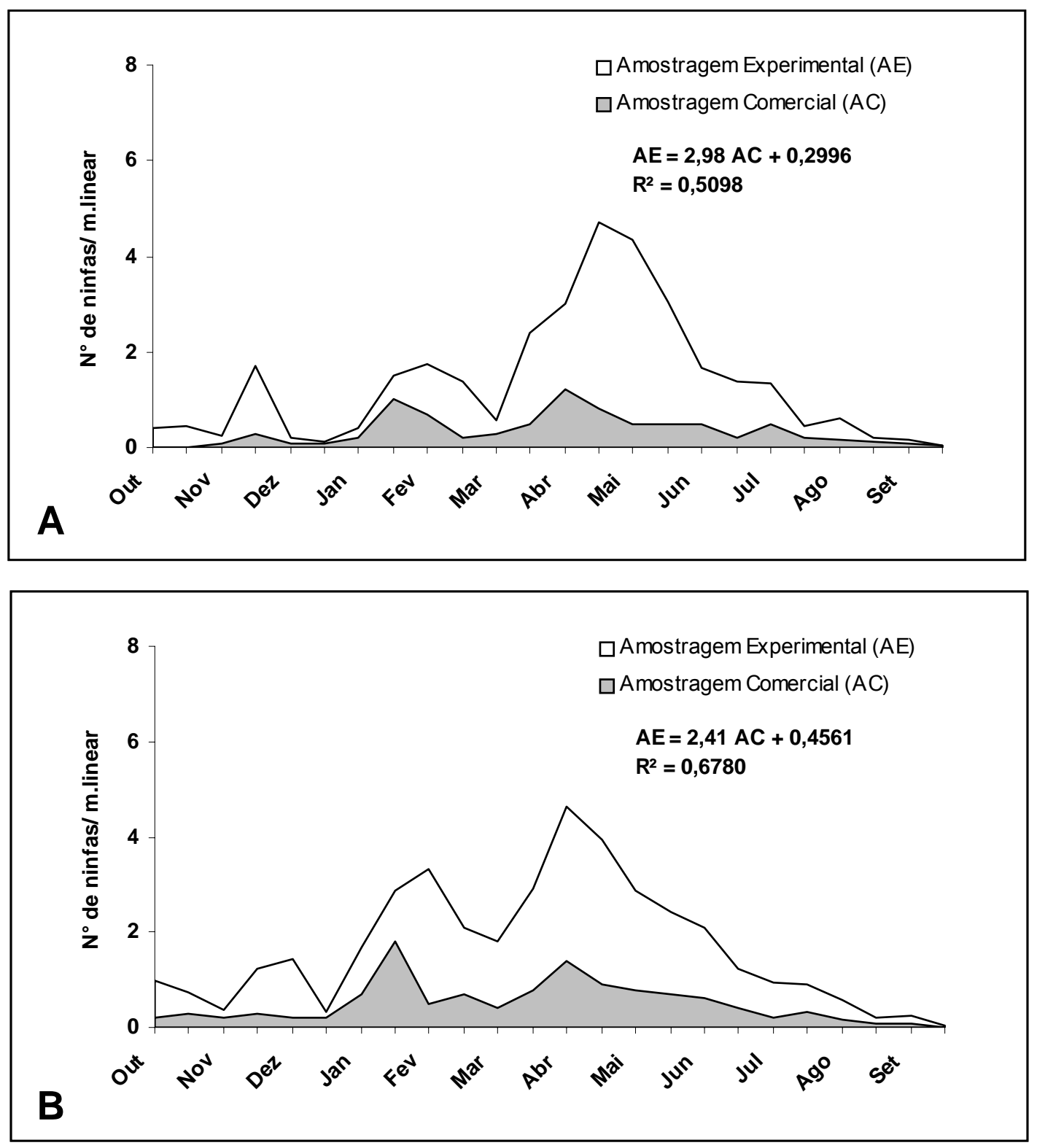

Figura 16 -Equação de regressão linear, coeficiente de determinação e flutuação populacional de adultos da cigarrinha-das-raízes da cana-de-açúcar, Mahanarva fimbriolata, para comparação dos dados da Amostragem Comercial (AC) e Amostragem Experimental (AE), realizadas nas Fazendas Bela Vista (A) e Água Suja (B), em Ourinhos-SP, entre os meses de outubro de 2003 e setembro de 2004 


\subsubsection{Relação entre número de espumas e ninfas}

Foi observada uma alta correlação entre o número de espumas e ninfas das cigarrinha-das-raízes, $M$. fimbriolata, presentes na base das touceiras de cana-deaçúcar, em ambos os sistemas de amostragem, AC e AE, nas duas propriedades, com coeficientes de determinação superiores a 0,96 (Figuras 17 e 18).

Estes resultados indicam que, independentemente da época de avaliação e do nível de infestação, foi possível estimar a população de ninfas da cigarrinha-dasraízes em cana-de-açúcar, por meio da contagem de espumas, com elevado grau de confiabilidade.

O emprego da amostragem da cigarrinha-das-raízes por meio da contagem de espumas e não ninfas, como vem sendo realizado atualmente (Mendonça, 1996; Almeida, 2001; Novaretti et al., 2001; Macedo et al., 2002; Dinardo-Miranda, 2003), poderá contribuir sobremaneira para a redução dos custos da amostragem desta praga. Além disso, pode até mesmo viabilizar um aumento no tamanho da amostra visando melhorar seu nível de precisão (vide item 4.1.3). Entretanto, para implementação desta técnica deve-se atentar para a padronização dos critérios de contagem do número de espumas e um bom treinamento das equipes de monitoramento. 

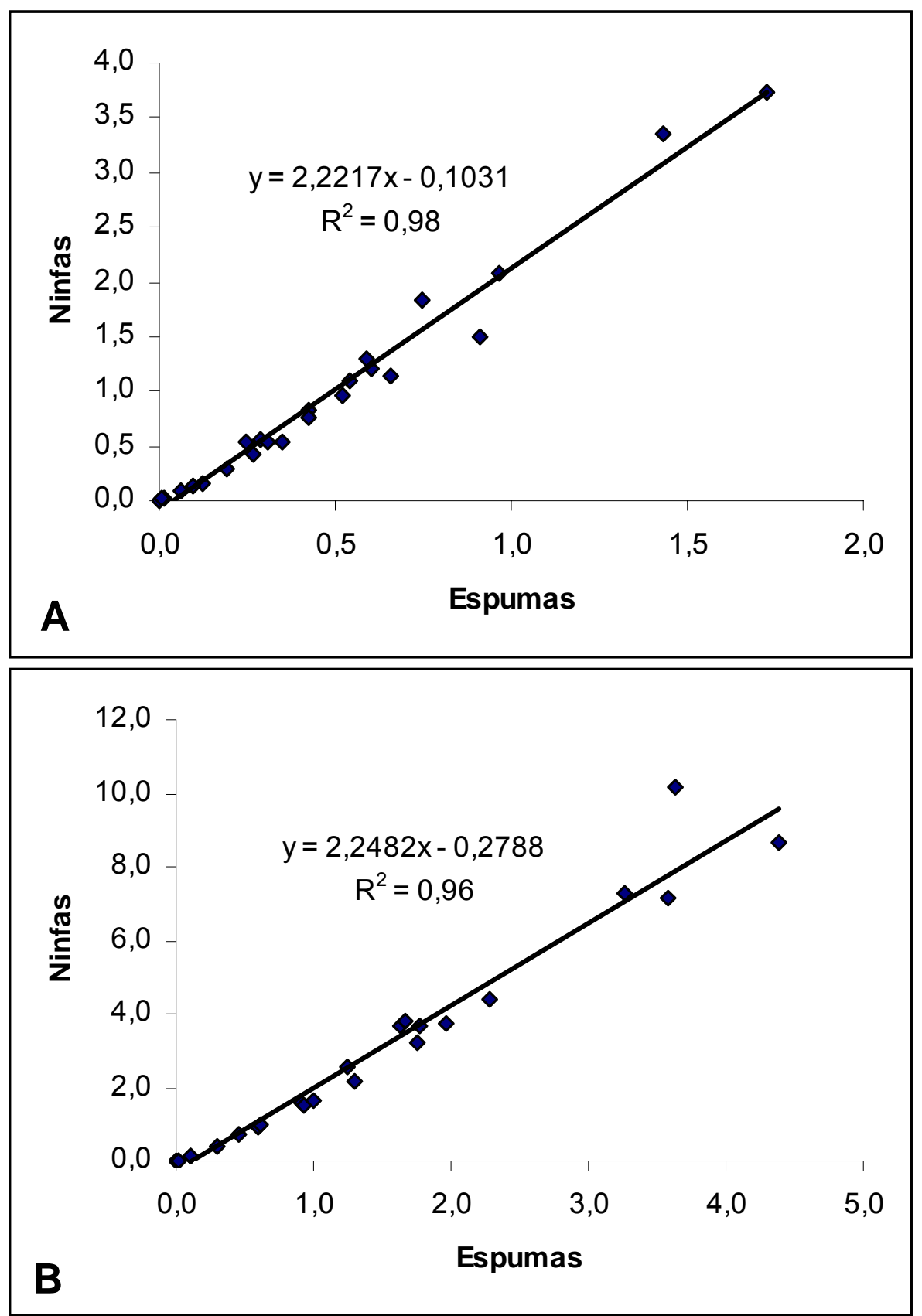

Figura 17 -Relação entre o número de espumas e ninfas da cigarrinha-das-raízes, Mahanarva fimbriolata, em cana-de-açúcar, obtida na Amostragem Comercial (A) e Amostragem Experimental (B) realizada na Fazenda Água Suja em Ourinhos-SP 

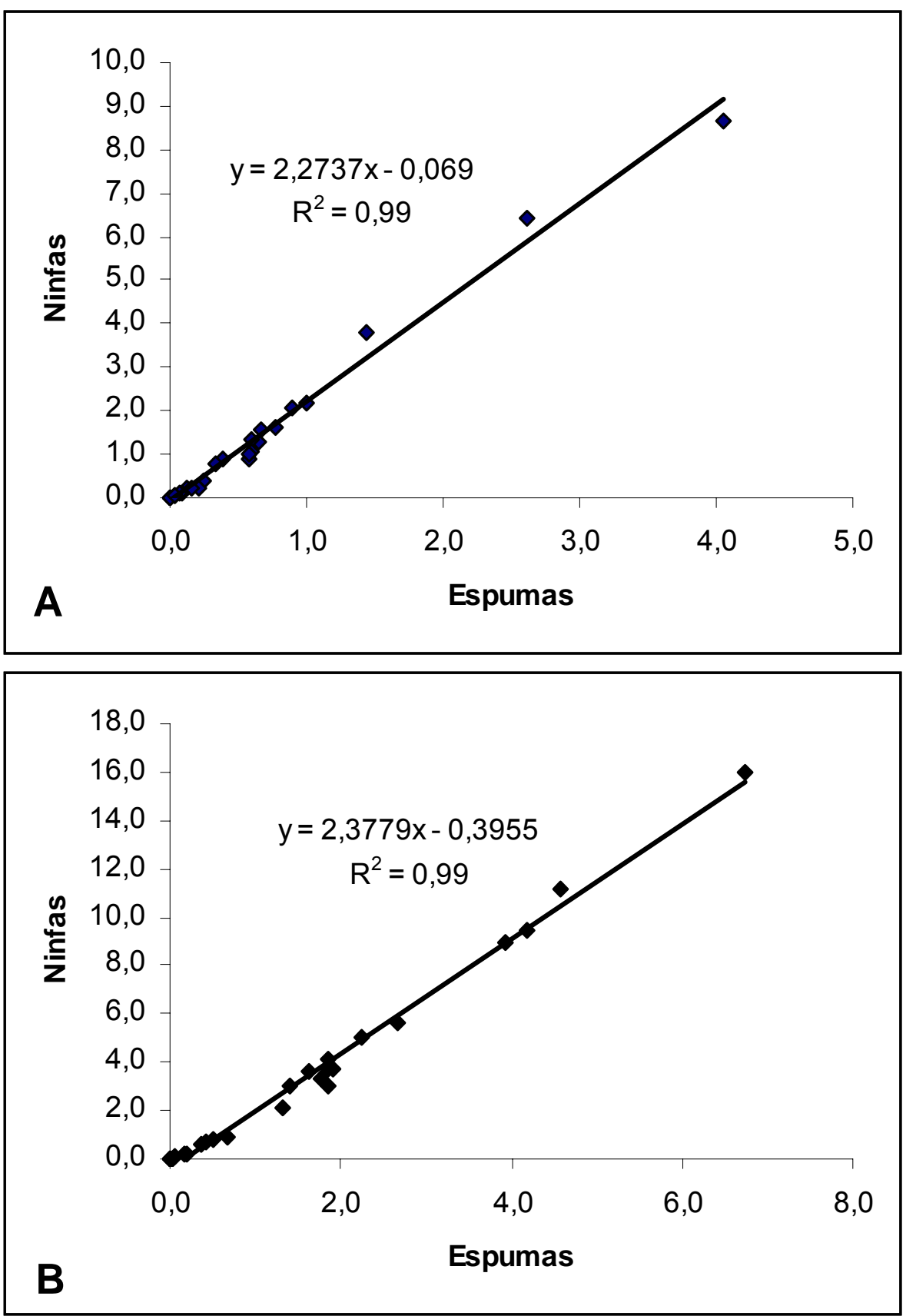

Figura 18 -Relação entre o número de espumas e ninfas da cigarrinha-das-raízes, Mahanarva fimbriolata, em cana-de-açúcar, obtida na Amostragem Comercial $(A)$ e Amostragem Experimental (B) realizada na Fazenda Água Suja em Ourinhos-SP 


\section{CONCLUSÕES}

Os estudos de distribuição espacial, eficiência do sistema de amostragem e estimativa da população de ninfas por meio da contagem de espumas na cigarrinha-das-raízes da cana-de-açúcar, Mahanarva fimbriolata (Stål., 1854) (Hemiptera: Cercopidae) permitem concluir que:

- Adultos e ninfas da cigarrinha-das-raízes, M. fimbriolata, se distribuem de forma agregada ou contagiosa na cultura da cana-de-açúcar, independentemente da época de amostragem, nível de infestação e variedade cultivada;

- O plano de amostragem mais adequado para o monitoramento da cigarrinha-dasraízes em cana-de-açúcar consiste na tomada de 18 amostras de 1 metro linear por hectare, distribuídas na área de forma sistemática;

- O sistema de amostragem atualmente utilizado pelos produtores, por ser empírico, deve ser substituído pelo plano de amostragem proposto;

- É possível estimar a população de ninfas da cigarrinha-das-raízes por meio da contagem de espumas, com elevado grau de confiabilidade. 


\section{REFERÊNCIAS BIBLIOGRÁFICAS}

ABRAMO FILHO, J. Decomposição da palha da cana-de-açúcar em canavial colhido, sem queima, mecanicamente. Rio Claro, 1995. 91p. Dissertação (Mestrado) Instituto de Biociências, Universidade Estadual Paulista. "Julio de Mesquita F”".

ALMEIDA, J.E.M. Controle biológico da cigarrinha da raiz da cana-de-açúcar com isolados de Metarhizium anisopliae. In: REUNIÃO ITINERANTE DE FITOSSANIDADE DO INSTITUTO BIOLÓGICO - CANA-DE-AÇÚCAR, 5., Sertãozinho, 2001. Anais. Sertãozinho: Instituto Biológico, 2001. p.35-47.

ALMEIDA, L.C. Cigarrinhas: aspectos gerais e importância econômica (compact disc). In: PRAGAS DA CANA-DE-AÇÚCAR: IMPORTÂNCIA ECONÔMICA E ENFOQUES ATUAIS, Piracicaba, 2002. Organização: STAB, Copersucar, IAC. Piracicaba: Centro de Tecnologia Copersucar, 2002.

ARRIGONI, E.D.B. Pragas diversas em cana crua. In: SEMANA DA CANA-DEAÇÚCAR DE PIRACICABA, 4., Piracicaba, 1999. Anais. Piracicaba: AFOCAPI, 1999. p.38-39.

ASCOMBE, F.J. The statistical analisys of insect counts based on the negative binomial distribution. Biometrics, v.5, p.165-173, 1949.

ASCOMBE, F.J. Sampling theory of the negative binomial and logarithmic series distributions. Biometrics. v.37, p.358-382, 1950.

AZZI, G.M.; DODSON, A.K. Infestação de cigarrinha-da-raiz em canaviais de Piracicaba - SP (Mahanarva fimbriolata Stål). Brasil Açucareiro, v.77, n.5, p.3642, mai. 1971.

BALBO JUNIOR., W.; MOSSIM, G.C. Ocorrência e tentativa de controle de pragas em cana crua na Usina Santo Antônio. In: SEMANA DA CANA-DE-AÇÚCAR DE PIRACICABA, 4., Piracicaba, 1999. Anais. Piracicaba: AFOCAPI, 1999. p.40-42. 
BALBO L. Aspectos gerais da colheita e processamento da cana-de-açúcar. In: KIRCHOFF, V.W.J.H. (Ed.). As queimadas da cana. São José dos Campos: INPE, 1991. p.41-42.

BAPTISTA, A.C. "Queima de cigarrinha" da cana-de-açúcar. Brasil Açucareiro, v.36, n.1, p.82, 1950.

BATISTA FILHO, A.; LEITE, L.G.; TAKADA, H.M.; LAMAS, C.; RAMIRO, Z.A. Incidência do fungo entomopatogênico Batkoa apiculata (Entomophthorales) sobre a cigarrinha das pastagens em Pindamonhangaba - SP. In: REUNIÃO ANUAL DO INSTITUTO BIOLÓGICO, 10., São Paulo, 1997. Resumos. São Paulo: Arquivos do Instituto Biológico, v.64. p.82. 1997.

BIANCO, R. Disposicion espacial de Aeneolamia spp. (Homoptera: Cercopidae) en praderas de gramíneas tropicales. Chapingo, México, 1982. 123p. Tesis (Maestro en Ciencias) - Institución de Enseñanza e Investigación en Ciencias Agrícolas, CP Colegio de Postgraduados.

BLISS, C.I.; FISHER, R.A. Fitting the negative binomial distribution to biological data. Biometrics, v.9, p.176-200, 1953.

BOTELHO, P.S.M.; MENDES, A.C.; MACEDO, N.; SILVEIRA NETO, S. Atração da cigarrinha da raiz Mahanarva fimbriolata (Stål 1854) (Homoptera: Cercopidae), por luzes de diferentes comprimentos de onda. Brasil Açucareiro, v.88, n.3, p.37-42, 1976.

BOTELHO, P.S.M.; MENDES, A.C.; MACEDO, N.; SILVEIRA NETO, S. Curva populacional de Mahanarva fimbriolata em Araras-SP, e sua dependência com o balanço hídrico da região. Brasil Açucareiro, v.90, n.3, p.11-17, 1977.

BORROR, D.J.; DELONG, D.M. Introdução ao estudo dos insetos. São Paulo: Edgard-Blücher, 1969, 653p.

CAMINHA FILHO, A. A cigarrinha dos canaviais em Sergipe. Brasil Açucareiro, v.25, n.1, p.92-97, 1945.

CENTRO DE TECNOlOgIA COPERSUCAR. Projeto Cana Crua - Aspectos agronômicos: atividades e resultados. Piracicaba, 1993, 25.p. (Relatório Interno).

COSTA LIMA, A. Insetos do Brasil. Rio de Janeiro: Escola Nacional de Agronomia, 1942. v.3, p.65-80: Cercopoidea.

DANTAS, B.; FARIAS, E.L.; FRANCO, E. Combate aero-químico à cigarrinha dos canaviais em Sergipe. Brasil Açucareiro, v.40, n.2, p.104-113, 1952. 
DINARDO-MIRANDA, L. L. Cigarrinhas em cana crua. In: SEMANA DA CANA-DEAÇÚCAR DE PIRACICABA, 4., Piracicaba, 1999. Anais. Piracicaba: AFOCAPI, 1999. p.36-37.

DINARDO-MIRANDA, L. L. O papel da retirada da palha no manejo da cigarrinha das raízes. STAB, v.20, n.5, p.23, 2002.

DINARDO-MIRANDA, L. L.; FERREIRA, J.M.G.; DURIGAN, P.A.M. Influência das cigarrinhas das raízes (Mahanarva fimbriolata) sobre a qualidade tecnológica da cana-de-açúcar. STAB, v.19, n.2, p.34-35, 2000.

DINARDO-MIRANDA, L. L.; FERREIRA, J.M.G.; CARVALHO, P.A.M. Influência da época de colheita e do genótipo de cana-de-açúcar sobre a infestação de Mahanarva fimbriolata (Stål) (Hemiptera: Cercopidae). Neotropical Entomology, v.30, n.1, p.145-149, 2001.

DINARDO-MIRANDA, L. L.; FERREIRA, J.M.G.; CARVALHO, A.M.P.R.; BARBOSA, V. Eficiência de inseticidas e medidas culturais no controle de Mahanarva fimbriolata em cana-de-açúcar. STAB, v.18, n.3, p.34-36, 2000.

DINARDO-MIRANDA, L. L.; FIGUEIREDO, P.; LANDELL, M.G.A.; FERREIRA, J.M.G.; CARVALHO, P.A.M. Danos causados pelas cigarrinhas das raízes (Mahanarva fimbriolata) a diversos genótipos de cana-de-açúcar. STAB, v.17, n.5, p.48-53, 1999a.

DINARDO-MIRANDA, L. L.; NAKAMURA,G.; ZOTARELLI, L., BRAZE, B.A., EUZÉBIO, O. Viabilidade técnica e econômica de actara 250 WG, aplicado em diversas doses, no controle da cigarrinha-das-raízes. STAB, v.22, n.1, p.39-43, 2003.

EL-KADI, M.K. Novas perspectivas no controle de cigarrinhas. In: CONGRESSO BRASILEIRO DE ENTOMOLOGIA, 4., Goiânia, 1977. Conferências, palestras e exposições. Goiânia: SEB, 1977. p.-58-67.

ELLIOTT, J.M. Some methods for the statistical analysis of sample of benthic invertebrates. 2 ed. Occasional Publication. Freshwater Biological Association, Ambleside, n.25, 148p., 1979.

EMPRESA BRASILEIRA DE PESQUISA AGROPECUÁRIA. Centro Nacional de Pesquisa de Solos. Sistema brasileiro de classificação de solos. Rio de Janeiro, 1999. 412p. 
EVANS, D.E. The spatial distribution and sampling of Aeneolamia varia saccharina and A. postica jugata (Homoptera: Cercopidae). Entomologia Experimentalis et Applicata, v.15, n.3, p.305-318, 1972.

FENNAH, R. G. Revisionary notes on the new world genera of cercopid froghoppers (Homoptera: Cercopoidea). Bulletin of Entomological Research, v.58, n.1, p.165190, 1968.

FEWKES, D.W. The biology of sugarcane froghoppers In: WILLIAMS, J.R.; METCALFE, J.R., MUNGOMERY, R.W.; MATHES, R. (Ed.). Pests of sugarcane. Amsterdan: Elsevier Publishing, 1969. p.283-307.

FLINT, M.L.; VAN DEN BOSCH, R. Introduction to integrated pest management. New York: Plenum Press, 1981. 240p.

FNP CONSULTORIA \& COMÉRCIO. Agrianual 2005: anuário da agricultura brasileira. São Paulo, 2005.p.261-277: cana-de-açúcar.

FREIRE, A.M.; SOUTO, C.E.R.; MARQUES, E.J. Combate biológico das cigarrinhas da cana-de-açúcar. Brasil Açucareiro, v.71, n.4, p.41-44, 1968.

GALLO, D.; NAKANO, O.; SILVEIRA NETO, S. et al. Manual de entomologia agrícola. 3.ed. Piracicaba: FEALQ, 2002. 920p.

GARCIA, J.F. Técnica de criação e tabela de vida de Mahanarva fimbriolata (Stål.,1854) (Hemiptera: cercopidae). Piracicaba, 2002. 59p. Dissertação (Mestrado) - Escola Superior de Agricultura “Luiz de Queiroz”, Universidade de São Paulo.

GARCIA, J.F.; APPEZZATO-DA-GLORIA, B.; GRISOTO, E.; PARRA, J.R.P.; BOTELHO, P.S.M. Sítio de alimentação da cigarrinha da raiz, Mahanarva fimbriolata (Stål.,1854) (Hemiptera: cercopidae) em cana-de-açúcar. In: CONGRESSO BRASILEIRO DE ENTOMOLOGIA, 20., Gramado, 2004. Resumos. Gramado: SEB, 2004. p.216.

GONÇALVES, J.S.; SOUZA. S.A.M. Proibição da queima de cana no Estado de São Paulo: simulações dos efeitos na área cultivada e na demanda pela força de trabalho. Informações Econômicas, v.28, n.3, p.21-40, 1998.

GUAGLIUMI, P. As cigarrinhas nos canaviais no Brasil. Súmula do relatório verbal apresentado à comissão executiva do IAA pelo entomologista professor Pietro Guagliumi. Brasil Açucareiro, v.68, n.3, p.08-11, 1966. 
GUAGLIUMI, P. As cigarrinhas dos canaviais no Brasil. I Contribuição: Perspectivas de uma luta biológica nos Estados de Pernambuco e Alagoas. Brasil Açucareiro, v.72, n.3, p.34-43, 1968.

GUAGLIUMI, P. Las "Cigarrinhas dos canaviais" en Brasil. (III Contribución). Aspectos generales del problema, con especial referencia a Mahanarva posticata en los Estados de Pernanbuco y Alagoas. Turrialba, v.19, n.3, p.321-331, 1969.

GUAGLIUMI, P. As cigarrinhas dos canaviais (HOM., Cercopidae) no Brasil. VI Contribuição: A nova nomenclatura e a distribuição das espécies mais importantes. Brasil Açucareiro, v.76, n.1, p.75-89, 1970.

GUAGLIUMI, P. Luta integrada contra as cigarrinhas da cana e das pastagens do nordeste do Brasil. Recife, Comissão Executiva de Defesa Sanitária da Lavoura Canavieira de Pernambuco, 1971. 41p. (Boletim, 3).

GUAGLIUMI, P. Sugestões para o combate das cigarrinhas da cana no nordeste do Brasil. Brasil Açucareiro, v.79, n.1, p.48-55, 1972.

GUAGLIUMI, P. Cigarrinha da raiz. In: GUAGLIUMI, P.(Ed.). Pragas da cana-deaçúcar. Nordeste do Brasil. Rio de Janeiro: IAA, 1972/1973. p.69-103 (Coleção canavieira, 10).

GRISOTO, E.; GARCIA, J.F. Altura de vôo da cigarrinha da raiz, Mahanarva fimbriolata (Stål, 1854) (Hemiptera: cercopidae), em cana-de-açúcar. In: SIMPÓSIO INTERNACIONAL DE INICIAÇÃO CIENTÍFICA DA UNIVERSIDADE DE SÃO PAULO, 11., Piracicaba, 2003. Resumos. Piracicaba: USP. 2003. p.6.

KOGAN, M.; HERZOG, D.C. (Ed.). Sampling methods in soybean entomology. Springer series in experimental entomology. New York: Springer Verlag, 1980. $587 p$.

LLOYD, M. Mean crowding. Journal of Animal Ecology, v.36, p.1-30, 1967.

MACEDO, N.; CAMPOS, M.B.S.; ARAUJO, J.R. Insetos nas raízes e colo da planta, perfilhamento e produtividade em canaviais colhidos com e sem queima. STAB, v.15, n.3, p.18-21, 1997.

MACEDO, N.; BOTELHO, P.S.M.; RIBEIRO, L.D.; STUPIELLO, J.J.; PETRI, J.; OLIVEIRA, P.F.M.; SOARES, R.A.B. Número e época de aplicações de inseticidas no controle de cigarrinha da raiz Mahanarva fimbriolata, em cana-de-açúcar (compact disc). In: CONGRESSO BRASILEIRO DE ENTOMOLOGIA, 19., Manaus, 2002. Anais. Manaus: SEB, 2002. 
MARICONI, F.A.M. Inseticidas e seu emprego no combate às pragas. 2.ed. São Paulo: Biblioteca Agronômica Ceres, 1963. 607p.

MENDES, A.C. Influência dos elementos climáticos sobre a população da broca da cana-de-açúcar Diatraea saccharalis (Fabr.). e da cigarrinha da raiz, Mahanarva fimbriolata (Stål). Araras - São Paulo. Piracicaba, 1976. 104p. Dissertação (Mestrado) - Escola Superior de Agricultura "Luiz de Queiroz", Universidade de São Paulo.

MENDES, A.C.; BOTELHO, P.S.M.; MACEDO, N.; SILVEIRA NETO, S. Behavior of the adults of the root froghopper, Mahanarva fimbriolata (Stål, 1854) (Hom., Cercopidae), according to climatic parameters. In: INTERNATIONAL SOCIETY OF SUGAR CANE TECHNOLOGISTS CONGRESS, 16., São Paulo, 1977. Proceedings. São Paulo: The Executive Committee of the I.S.S.C.T., 1977. p.617631.

MENDONÇA, A. F. Controle integrado de pragas da cana-de-açúcar na América Latina e Caribe. In: CONGRESSO BRASILEIRO DE ENTOMOLOGIA, 10., Rio de Janeiro, 1986. Mesa Redonda sobre Controle Integrado de Pragas da cana-de-açúcar na América latina e Caribe, Rio de Janeiro, 1986. 24p.

MENDONÇA, A. F. Introdução da cigarrinha da raiz da cana-de-açúcar Mahanarva fimbriolata (Stål), no Estado de Alagoas, Brasil: Importância econômica e controle. In: CONGRESSO NACIONAL DA SOCIEDADE DOS TÉCNICOS AÇUCAREIROS E ALCOOLEIROS DO BRASIL, 6., Maceió, 1996. Anais. STAB, Piracicaba. 1996. p.207-217.

MENDONÇA, A. F.; BARBOSA, G.F.S.; MARQUES, J.E. As cigarrinhas da cana-deaçúcar (Hemiptera: Cercopidae) no Brasil. In: MENDONÇA, A. F., (Ed.). Pragas da cana-de-açúcar. Maceió: Edição do autor. 1996a, p.171-192.

MEYER, E.; RICHARD, C. Sugarcane harvesting: what choices are there? Sugar Journal, v.58, n.9, p.23-25, 1996.

MOREIRA, C. A cigarrinha da canna de assucar. Almanak Agrícola Brazileiro, v.10, p.141-142, 1921.

MOREIRA, C. A cigarrinha vermelha da canna de assucar (Tomaspis liturata Lep. \& Serv.). Boletim do Instituto Biológico de Defesa Agrícola, v.4, p.1-23, 1925.

MORISITA, M. Measuring of dispersion of individuals and analysis, of the distributional patterns. Mem. Fac. Sci. Kyushi Ser. e Biol., Fukuoka, v.2, n.4 p.215-235, 1959. 
MORISITA, M. $I_{\delta}$ index, a measure of dispersion of individuals. Researches on Population Ecology. v.4 p.1-7, 1962.

NILAKHE, S.S. Amostragem de ninfas de cigarrinhas em pastagens de Brachiaria decumbens Stapf. Campo Grande, MS: EMBRAPA_CNPGC, 1982. 67p. (EMBRAPA_CNPGC, Boletim de Pesquisa, 2).

NORRIS, R. F.; CASWELL-CHEN, E. P.; KOGAN, M. Concepts in Integrated Pest Management. New Jersey: Prentice Hall, 2001. 608p.

NOVARETTI, W.R.T.; PAIVA, L.A.; BELLUCCI, E.; PIVETTA, J.P.; JORGE, E.A.; CAMPOS, R.; NEME, L.H.F.M. Efeito da aplicação dos produtos aldicarb $150 \mathrm{G}$ e fipronil 800 WG isolados ou em associação, no controle da cigarrinha das raízes da cana-de-açúcar. STAB, v.19, n.5, p.42-46, 2001.

PROGRAMA NACIONAL DE MELHORAMENTO DA CANA-DE-AÇÚCAR. Guia das principais pragas da cana-de-açúcar no Brasil. Piracicaba, 1977. 28p.

PROGRAMA NACIONAL DE MELHORAMENTO DA CANA-DE-AÇÚCAR. Guia das principias pragas da cana-de-açúcar no Brasil. Piracicaba, 1982. 28p.

RABINOVICH, J.E. Introducción a la ecologia de poblaciones animales. México: Comp. Ed. Continetal, 1980. 313p.

RIBEMBOIM, J.A. Medidas de controle à cigarrinha da cana-de-açúcar (Mahanarva indicata, Distant, 1909). Recife: Comissão Executiva de Defesa Sanitária da Lavoura Canavieira de Pernambuco, 1967. 22p. (Boletim, 25).

RUESINK, W.G. Introduction to sampling theory. In: KOGAN, M.; HERZOG, D.C. (Ed.). Sampling methods in soybean entomology. New York: Springer Verlag, 1980. cap.3, p.61-78.

SECCO, A. O tamanho do Brasil que põe a mesa. Revista Veja, n.1843, mar.2004.

SILVEIRA NETO, S. Monitoramento e decisão no controle de pragas. In: WILSON, B.C. (Org.) Manejo Integrado de Pragas. São Paulo: UNESP-CETESB, 1990. cap.4, p.71-86.

SILVEIRA NETO, S.; CARVALHO, R.P.L.; PARANHOS, S.B. Flutuação da população de pragas da cana-de-açúcar em Piracicaba. In: REUNIÃO ANUAL DA SBE, 1., Piracicaba, 1968. Anais. Piracicaba: SBE, 1968. p.26-27.

SILVEIRA NETO, S.; NAKANO, O.; BARBIN, D. et al. Manual de ecologia dos insetos. São Paulo: Ceres, 1976. 419p. 
SOUZA, H.D. A cigarrinha nos canaviais de Sergipe, Alagoas, Pernambuco e Bahia. Brasil Açucareiro, v.32, n.11, p.446-454, 1948.

SOUZA, H.D. As cigarrinhas da cana-de-açúcar e seu controle por inimigos naturais. Rio de Janeiro: IAA, 1967. 19p.

SOUTHWOOD, T.R.E. Ecological Methods. 2.ed. New York: John Wiley, 1978. 525p. STERLING, W.L.; BLEICHER, E.; JESUS F.M.M. Um programa de manejo integrado para insetos do algodoeiro no nordeste do Brasil usando amostragem seqüencial. Anais da Sociedade Entomológica do Brasil, v.12, n.1, p.85-98, 1983.

TAYLOR, L.R. Aggregation, variance and the mean. Nature, v.189, p.732-735, 1961.

TAYLOR, L.R. A natural law for the spatial disposition of insects. In: INTERNATIONAL ENTOMOLOGY CONGRESS, 12. London, 1965. Proceedings, London: Cambridge University Press, 1965. p.396-397.

TERÁN, F.O. Pragas da cana-de-açúcar. In: PARANHOS, S.B. (Ed.). Cana-de-açúcar cultivo e utilização. Campinas: Fundação Cargill, 1987, v.2, p.601-698.

TERÁN, F.O.; PRECETTI, A.A.C.M. Outras pragas da cana-de-açúcar. In: REUNIÃO TÉCNICA AGRONÔMICA: PRAGAS DA CANA-DE-AÇÚCAR.. São Paulo, 1983. São Paulo: Copersucar, 1983. p.45-55.

THOMPSON, V. Associative nitrogen fixation, C4 photosynthesis, and the evolution of spittlebugs (Hemiptera: cercopidae) as major pests of neotropical sugarcane and forage grasses. Bulletin of Entomological Research. v.94, n.1, p.189-200, 2004.

UNICA - Sociedade: Desenvolvimento sustentável e mercado de trabalho. http://www.unica.com.br/pages/sociedade mercado1.asp (19 mar. 2005).

VEIGA, F.M. A cigarrinha dos canaviais. Brasil Açucareiro, v.64, n.6, p.9-16, 1964.

WILSON, L.T. Estimating the abundance and impact of arthropod natural enemies on IPM systems. In: HOY, M.A., HERZOG, D.C. (Ed.). Biological control in agricultural IPM systems. London: Academic press, 1985. p.303-322.

WILSON, L.T.; TERLING, W.L.; RUMMEL, D.R.; DEVAY, J.E. Quantitative sampling principles in cotton IPM. In: FRISBIE, R.E.; EL-ZIK, K.M.; WILSON, L.T. (Ed.). Integrated pest management systems and cotton production. New York: John Wiley, Inc, 1989, p.85-119.

ZUCCHI, R.A.; SILVEIRA NETO, S.; NAKANO, O. Guia de identificação de pragas agrícolas. Piracicaba: FEALQ, 1993. 139p. 